\title{
Cova de les Malladetes (Valencia, Spain): New Insights About the Early Upper Palaeolithic in the Mediterranean Basin of the Iberian Peninsula
}

\author{
Valentín Villaverde $^{1}$ (D) Alfred Sanchis $^{2} \cdot$ Ernestina Badal $^{1}$. \\ Miguel Ángel Bel ${ }^{1}$ - M. Mercè Bergadà ${ }^{3}$. Aleix Eixea ${ }^{1}$ - Pere M. Guillem ${ }^{4}$. \\ Álvaro Martínez-Alfaro ${ }^{1} \cdot$ Rafael Martínez-Valle $^{5} \cdot$ Carmen M. Martínez-Varea $^{1}$. \\ Cristina Real ${ }^{1} \cdot$ Peter Steier $^{6}$. Eva M. Wild ${ }^{6}$
}

Accepted: 12 November 2020 / Published online: 13 March 2021

(C) The Author(s) 2021

\begin{abstract}
New excavations carried out at Cova de les Malladetes confirm and improve previous information on the archaeological sequence of this site. A total of 29 new dates allow to specify the chronology of the Aurignacian (levels XIVA-XII) and Gravettian (levels XI-VII). Furthermore, concerning the results obtained during the 1970 excavation, three new levels were identified: level XIVB, which represents a short temporal human occupation hiatus, and levels XV and XVI with some hearths and anthropic evidence, although the lithic material does not permit a cultural attribution. This paper presents data obtained from the analysis of archaeobotanical, micro- and macrofaunal assemblages and lithic and osseous industry. Results are relevant concerning the palaeoclimatic and palaeoenvironmental characterisation of the Early Upper Palaeolithic, as well as for assessing the human occupation patterns during the Gravettian and Aurignacian. Moreover, we evaluate the chronological implications of the basal levels (XIVB, XV and XVI), drawing attention to the absence of an important temporal gap between this phase and the start of the Early Upper Palaeolithic at the site. Finally, our new data extend the information provided by other sites in the Spanish Mediterranean region, allowing a more defined characterisation of the Early Upper Palaeolithic, especially regarding the Evolved Aurignacian chronology and its technotypological structure, with the presence of Roc-de-Combe subtype Dufour bladelets.
\end{abstract}

Keywords Early Upper Palaeolithic · Aurignacian · Gravettian · Spanish Mediterranean region

To F.J. Fortea Pérez (1946-2009) In memoriam

Valentín Villaverde

valentin.villaverde@uv.es

Extended author information available on the last page of the article 


\section{Introduction}

The Early Upper Palaeolithic (EUP) in the south of the Iberian Peninsula has been the subject of much attention in recent years in terms of both the period's sequential and chronological aspects (Bicho et al. 2015, 2017; Cortés-Sánchez et al. 2019; De la Peña 2013a, 2019; De la Peña and Vega 2013; Zilhão et al. 2017; Villaverde et al. 2019), and its demographics (Maier and Zimmermann 2017; Schmidt and Zimmermann 2019), technology (Bradtmöller et al. 2016; Marreiros and Bicho 2013), animal resource exploitation (Lloveras et al. 2016; Sanchis et al. 2016; Verdún-Castelló and Casabó 2020; Villaverde et al. 2007, 2019) and behavioural adaptations to environmental shifts (Barton et al. 2013). In the Mediterranean region of the Iberian Peninsula, a significant part of the debate focused on the chronology of the origins of the EUP and the evaluation of the Aurignacian entity. Although the documentation has undergone considerable changes with the excavation of a number of assemblages, such as La Boja and Finca de Doña Martina rock shelters (Mula, Murcia) (Zilhão et al. 2017), Cendres (Teulada-Moraira, Alicante) (Villaverde et al. 2019) and El Palomar (Yeste, Albacete) (De la Peña 2012a, 2012b; Vega and Martín 2006), and review of earlier excavations, such as Malladetes (Barx, Valencia) (De la Peña 2013b), Nerja (Maro, Málaga) (Aura Tortosa et al. 2012) and Bajondillo (Torremolinos, Málaga) (CortésSánchez 2007; Cortés-Sánchez et al. 2019), information is still scarce. The characterisation of the evolution of the EUP in the Mediterranean Iberian region has some limitations: there are few sequences that include Aurignacian and Gravettian levels; frequently, the lithic industry is scarce, especially in the Aurignacian; at some sites, the excavated areas are small, so they present issues when studying the occupation spatial patterns or the functionality of settlements; some sequences present stratigraphical problems derived from postdepositional alterations, as well as from possible mixing between levels during the excavation process; and finally, the assemblage of dates is heterogeneous (Bradtmöller et al. 2012).

Additionally, the characterisation of the Middle Palaeolithic to EUP transition is also affected by the reduced number of sites with archaeological levels from both periods. Excluding the septentrional part of the Mediterranean region, sites where these periods have been documented are Beneito (Iturbe et al. 1993), La Boja and Finca de Doña Martina (Zilhão et al. 2017), El Palomar (De la Peña 2012a, 2012b), El Niño (Davidson and García-Moreno 2013; García-Moreno et al. 2014), Bajondillo (Cortés-Sánchez 2007; Cortés-Sánchez et al. 2019), Sima de las Palomas de Teba (Kehl et al. 2016) and Gorham's Cave (Finlayson et al. 2006, 2008).

Cova de les Malladetes (also known as Cova de les Mallaetes) has been a key site in the systematisation of the Upper Palaeolithic sequence in the Iberian Mediterranean region ever since the results of the 1970 excavation were published (Fortea and Jordá 1976). Afterwards, various studies have provided palaeoenvironmental (Dupré 1980; Fumanal 1986), economic (Bailey and Davidson 1983; Davidson 1976, 1989) and palaeoanthropological information (Arsuaga et al. 2002) and have expanded on the industrial data from the Gravettian levels excavated in the 1940s (De la Peña 2013b; Miralles 1982) and their interpretation within the regional context of Malladetes (Fortea et al. 1983; Fullola et al. 2007). The importance of this site is easily understood because of its proximity to Cova del Parpalló, which lies just over $3 \mathrm{~km}$ away and because of the greater stratigraphic precision of the data obtained from its archaeological sequence in 
the 1970 campaign. These studies confirmed the importance of the Gravettian (levels VIII-X) at the site and in the region, documenting this phase with greater sequential and evolutionary precision than in the nearby Parpalló (Pericot 1942). The 1970 campaign also made it possible to establish the existence of several underlying levels (XI-XIV) that were poor in lithic material, but their chronology and the comparison with the materials recovered in the excavations carried out at the site in the 1940s, especially the diagnostic bone industry (Fortea and Jordá 1976; Tejero 2013), suggested that the beginning of the sequence is linked to the Aurignacian.

However, the assignment of levels XI-XIV to the Aurignacian at Malladetes has been criticised by some authors who insisted on the difficulty of establishing the existence of levels without Gravettian materials in the sectors excavated in the 1940s and 1970 (De la Peña 2012a, b, 2013b), following the model that defends the perduration of the Middle Palaeolithic to Gravettian chronologies (De la Peña 2012a).

The presence of the Aurignacian within the regional context has been confirmed by the recent documentation of this industry at Cova de les Cendres (levels XVIC and XVID) (Villaverde et al. 2019) and at Abrigo de La Boja (levels OH15 to 20) (Zilhão et al. 2017), along with evidence appearing some years ago in levels B8 and B9 of Beneito (Iturbe et al. 1993). The scarcity of materials from the 1970 campaign at Malladetes and the lack of adequate series of dates did not help to clarify this matter in the cavity. Nevertheless, the excavation carried out in 2016 and 2017, the multidisciplinary results of which are presented in this paper, could help to clarify some of the discussed issues, especially regarding the features of the EUP sequence, through a complete set of dates of the Aurignacian and Gravettian levels, new archaeological evidence on the entity of the Aurignacian and palaeoenvironmental and economic evidence of the EUP at the site.

In the sequence of Malladetes, it is now possible to distinguish two large sections with different resolution levels: on the one hand, the sequence between levels VIIXIVA is clearly attributed to the EUP based on the industrial and chronological evidence, and on the other hand, the cultural attribution of the XV-XVI basal levels is problematic because their chronological framework (44.6-39.4 ka) falls in the discussed MP to EUP transition period and the lithic industry is not diagnostic, despite the evidence of human occupation.

Therefore, the new data provided by the EUP sequence at Cova de les Malladetes are particularly interesting because they not only help shed light on the debate regarding the characterisation of the Aurignacian in the EUP sequence at this site, but also complement and confirm insights inferred from the results of the excavation of levels from the same chronology at Cendres and La Boja. Both the chronology of the beginning of the Upper Palaeolithic and the length of the perduration of the Middle Palaeolithic are topics of discussion.

\section{The Site}

Cova de les Malladetes is located in Barx (València) in the mountainous area of the Mondúver Massif (Fig. 1a); this massif integrates geological materials belonging to the Upper Cretaceous, which are represented by an important dolomitic mass in whose 

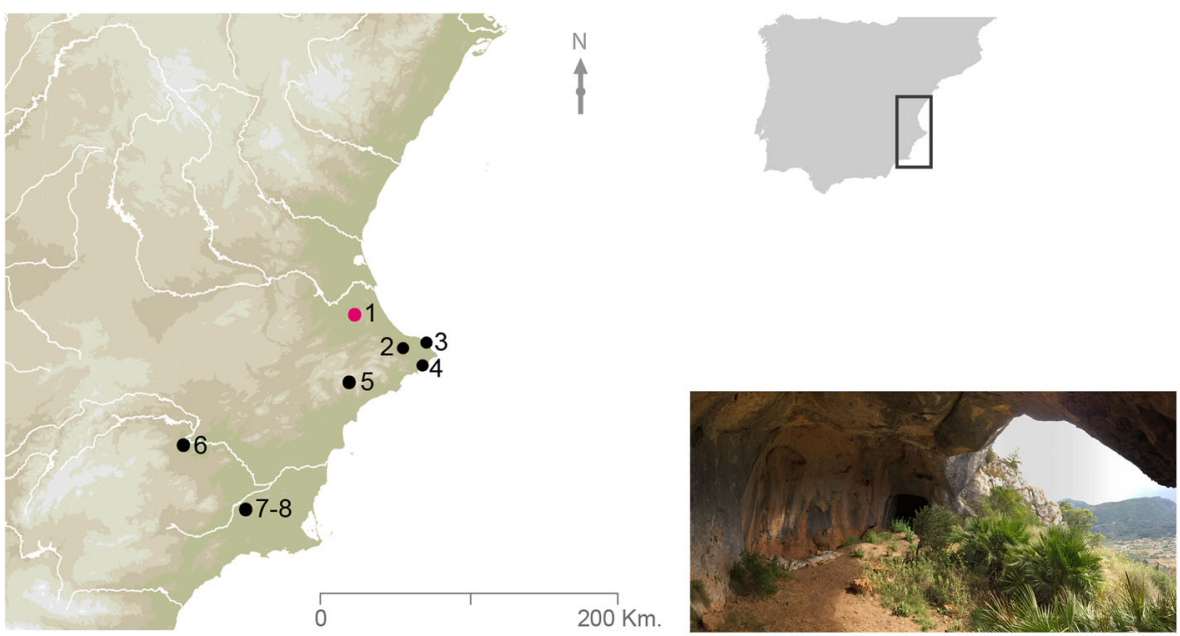

a

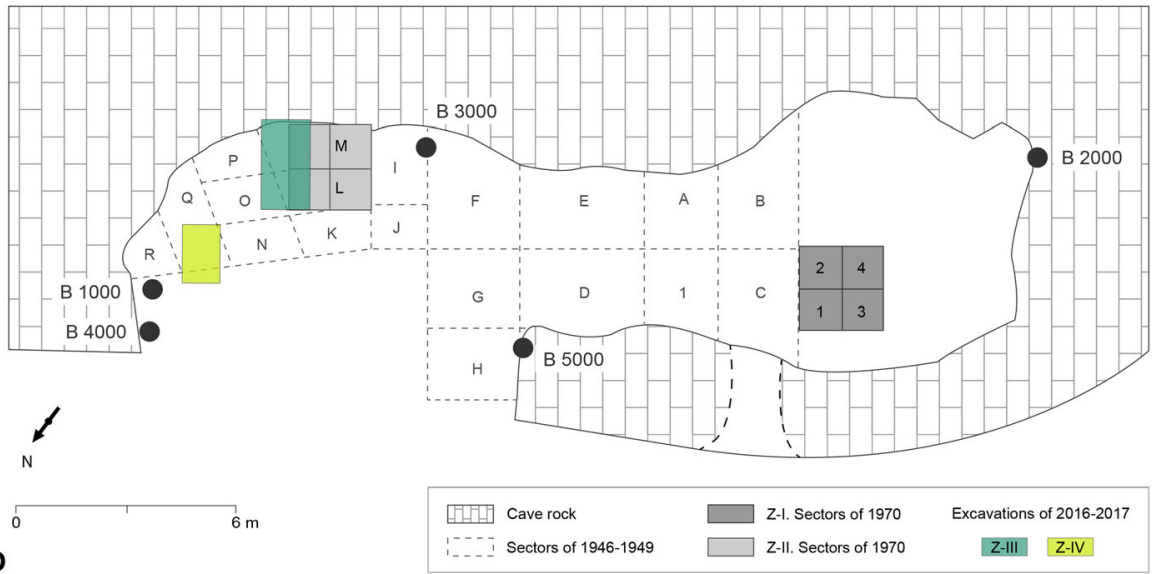

Fig. 1 Cova de les Malladetes. a Location of Cova de les Malladetes and other sites with EUP in the Iberian Mediterranean Basin: (1) Cova de les Malladetes, (2) Cova del Comte, (3) Cova Foradada, (4) Cova de les Cendres, (5) Cova Beneito, (6) Cueva Antón, (7) La Boja, (8) Finca de Doña Martina. b Plan of the cave with the excavation sectors

upper part there are limestone banks, followed by a dolomitic calcareous complex and sandy dolomites with siliceous conglomerate lenses.

The maximum height of the area corresponds to the vertex of Mondúver ( $840 \mathrm{~m}$ asl); other heights next to the cave are that of Penyalba, $773 \mathrm{~m}$ asl, and les Malladetes, 651 $\mathrm{m}$ asl.

The karstic system that developed in this limestone mass presents an important evolution. The ways of absorption are numerous and are favoured by its origin through the tectonic complication of the area, resulting in sink cavities, sinkholes and, especially, the Barx polje, which is located in a graben position at the foot of the slope where the Cova de les Malladetes opens in a depressed area at $300 \mathrm{~m}$ asl (Fumanal 1986). This large set of absorption and emissions of the karstic system is associated with numerous forms of conduction, which are currently relict and exposed by the 
retreat of the slopes. The appearance of certain levels in which these galleries abound is caused by their situation in the area of contact between calcareous and dolomitic banks, as can be observed in Cova de les Malladetes. Specifically, this conduit originated in favour of a fracture zone that would facilitate the infiltration and conduction of the water and its primitive hypogean circulation. In general, this karst massif presents a very advanced evolution of the polycyclic type, and its current feeding is autochthonous and is carried out by the contributions of atmospheric precipitation.

Cova de les Malladetes is located in the middle-upper part of the Malladetes slope (Fig. 2a) at $551 \mathrm{~m}$ asl in a senile zone created by lowering the level of the karstic base. The orientation of the entrance is northwest and opens in the cretaceous limestone of the Turonian-Senonian. The protruding morphology of the visor and walls means that its situation regarding the slope creates an ascent break with the lower unit (Fumanal 1986). The direction of the main axis of the conduit is southwest-northeast, and its approximate total area is $135 \mathrm{~m}^{2}$. It is configured as a rock shelter that can be accessed by a large main opening-oriented northwest (Fig. 2b) and another secondary $\mathrm{N}$
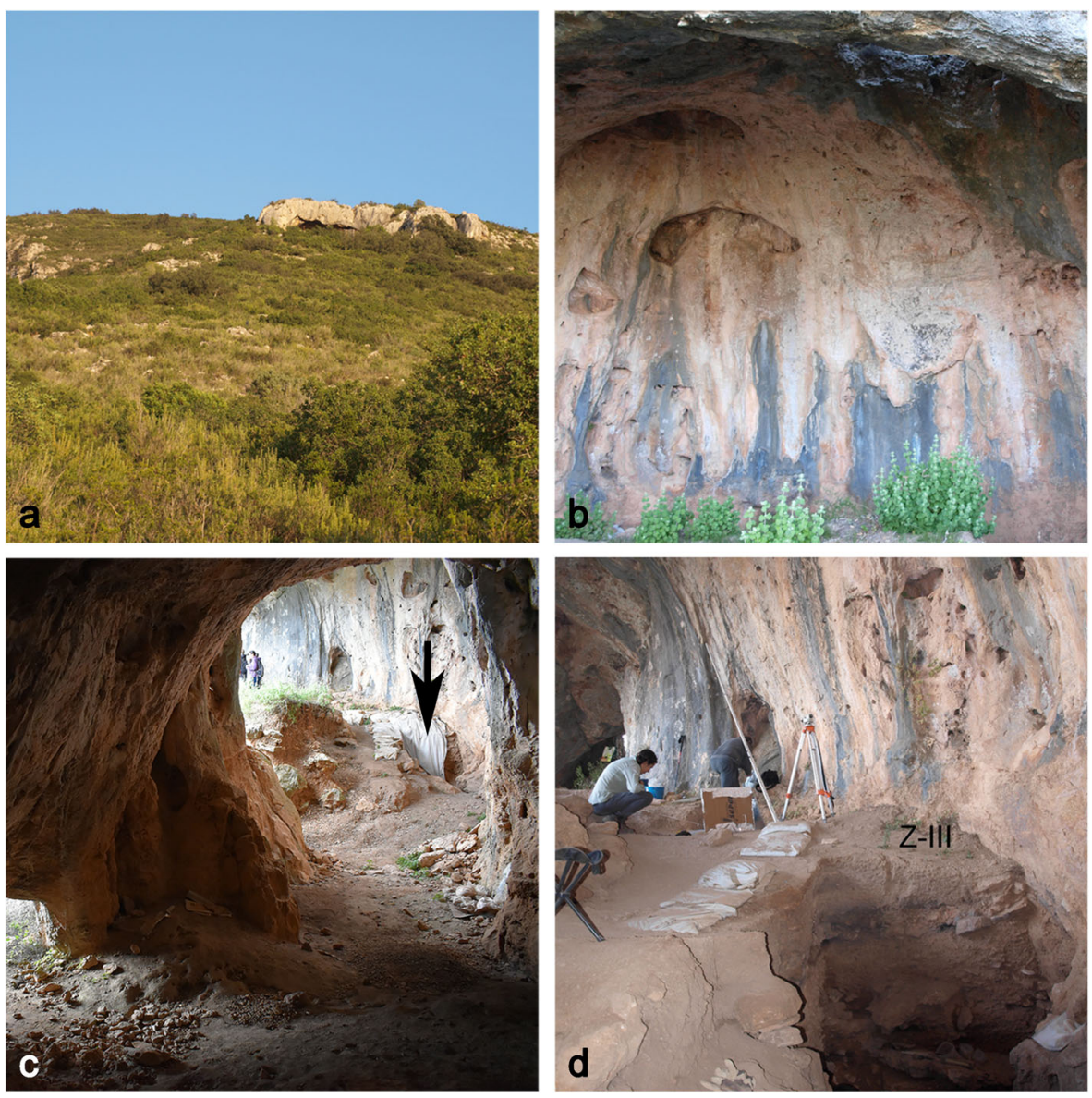

Fig. 2 Views of Cova de les Malladetes. a Outside view. b Main entrance of the site. c Cavity. The arrow poins to the location of sector Z-III. d Detail of the studied sector 
orientation. At another end of this rock shelter in the southwest direction, there is a cavity (Fig. 2b) of about $72 \mathrm{~m}^{2}$. On its south wall, there are some stalactites and small speleothems.

The first archaeological activities at Malladetes date back to 1946 and 1949, when a total of 19 sectors (Fig. 1b) were excavated. The surface area excavated was approximately $40 \mathrm{~m}^{2}$ and $39 \mathrm{~m}^{2}$ in the rock shelter area (sectors F, G, H and I covered $27 \mathrm{~m}^{2}$ and the rest covered $12 \mathrm{~m}^{2}$ ). Nevertheless, the depths of the excavation were uneven: in the cave part, the excavation ended at a depth of $3.35 \mathrm{~m}$ in sectors 1 , A and B, $2.55 \mathrm{~m}$ in sector C, $5.10 \mathrm{~m}$ in sector $\mathrm{D}$ and $5.50 \mathrm{~m}$ in sector $\mathrm{E}$. In the rock shelter area, a depth of $4.90 \mathrm{~m}$ was reached in sector F, approximately $1.30 \mathrm{~m}$ in sectors $\mathrm{G}$ and $\mathrm{H}$ and $3.40 \mathrm{~m}$ in sector I, whereas the depths were between 0.20 and $0.50 \mathrm{~m}$ in sectors $\mathrm{J}$ to R, so they were limited to the upper part of the fill, consisting mostly of post-Palaeolithic levels. The results of these excavations were basically unpublished.

A new excavation campaign was carried out in 1970 over two new sectors (Z-I and Z-II) (Fig. 1b). The West pit (Z-I) and East pit (Z-II) measured 4 and $6 \mathrm{~m}^{2}$ and reached a depth of 2.80 and $3.50 \mathrm{~m}$, respectively. Z-II coincided with the $1940 \mathrm{~s} \mathrm{M}$ and L sectors which were excavated only in the top $0.50 \mathrm{~m}$. As a result, a first description of the stratigraphy and sedimentary sequence of the site was provided, identifying 14 stratigraphic levels. Moreover, a first proposal of its cultural sequence was elaborated, recording a period spanning from the Aurignacian to recent prehistory (Fortea and Jordá 1976; Fumanal 1986).

It is important to stress that for various reasons, the base of the site was not reached in any of the sectors either in the 1940s or in the 1970 campaigns. The excavation was suspended because of the presence of large stone blocks or because of the sheer sparsity of recovered archaeological materials.

Subsequently, in 2016 and 2017, the site was excavated again to gain further insight into the the EUP and its chronology. Two new sectors were excavated. The first (Z-III) sought to extend Z-II from its eastern profile because it had been documented photographically and a detailed drawing of the stratigraphic profile was available. A maximum surface area of approximately $1.2 \times 2.5 \mathrm{~m}$ was excavated (Fig. $2 \mathrm{~d}$ ). The second (Z-IV), which was in an outer area, partly coincided with the old $\mathrm{N}$ sector and included part of the unexcavated surface of the site.

Because of the appearance of several large blocks during the excavation process of sector Z-III, which had mostly fallen from the walls of the cave, it was necessary to reduce the excavated surface and to echelon the profile (Fig. 3). However, when the 1979 basal level was reached, the surface area was increased to obtain a greater depth. We were able to continue at around $50-60 \mathrm{~cm}$ in depth from the 1970 basal level until the excavation had to be stopped because of lack of sufficient space and inadequate safety conditions; the base of the sedimentary fill could not be reached.

On the other hand, the upper levels of the 1970 profile had been considerably altered as a consequence of clandestine activities, meaning that the Solutrean levels (I-VI) could not be documented. Moreover, these alterations also affected levels VII and IX, so it has not been possible to document the archaeological remains properly as far as level X. To address this issue, another test pit (Z-IV) of $1 \times 1.5 \mathrm{~m}$ was dug in $2017 \mathrm{not}$ far from the previous one (Z-III) and was situated further away from the rocky wall of the shelter. Nevertheless, clandestine pits and the presence of large blocks limited the extent of the excavation, although we were able to obtain a range of interesting data 

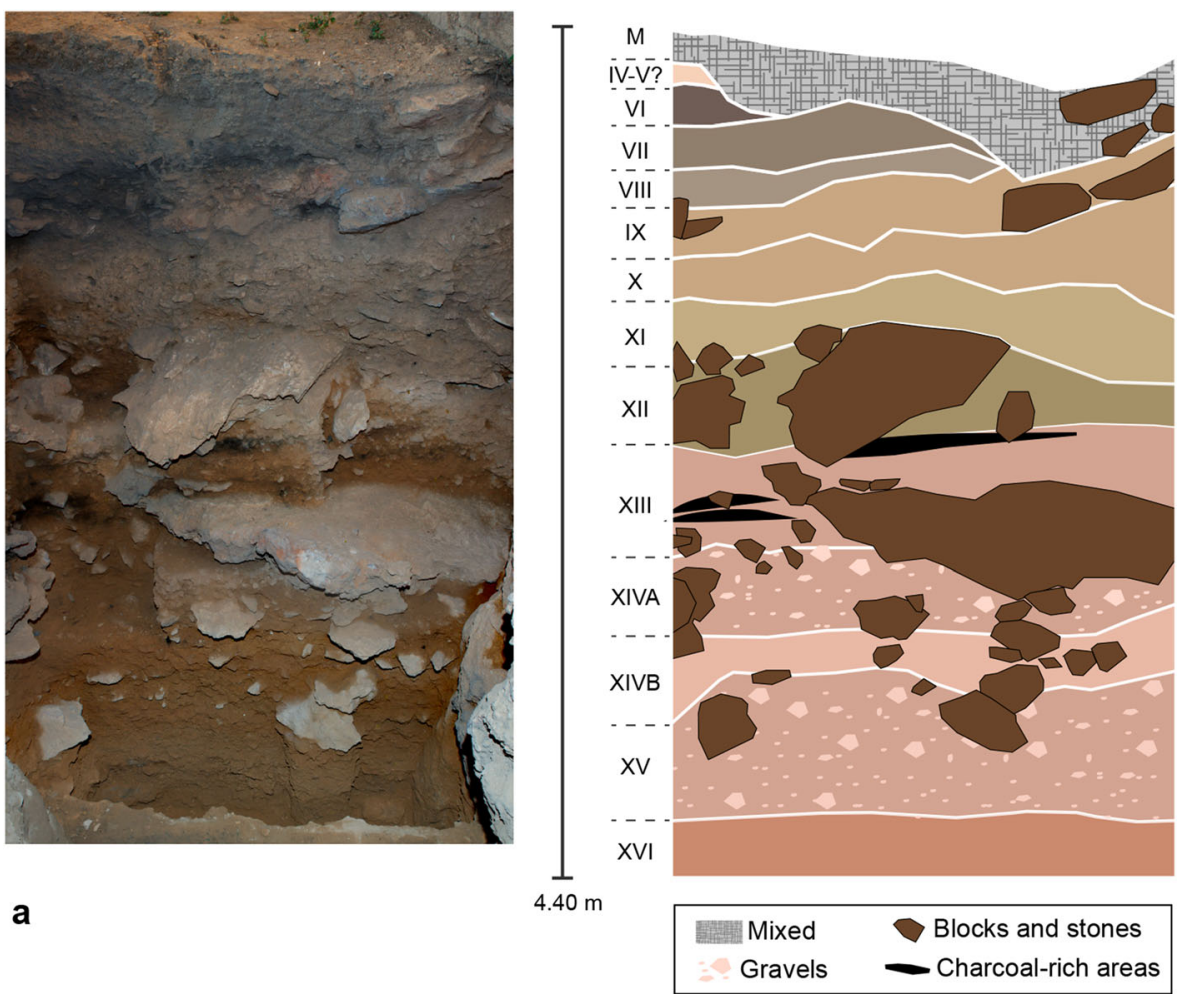

a
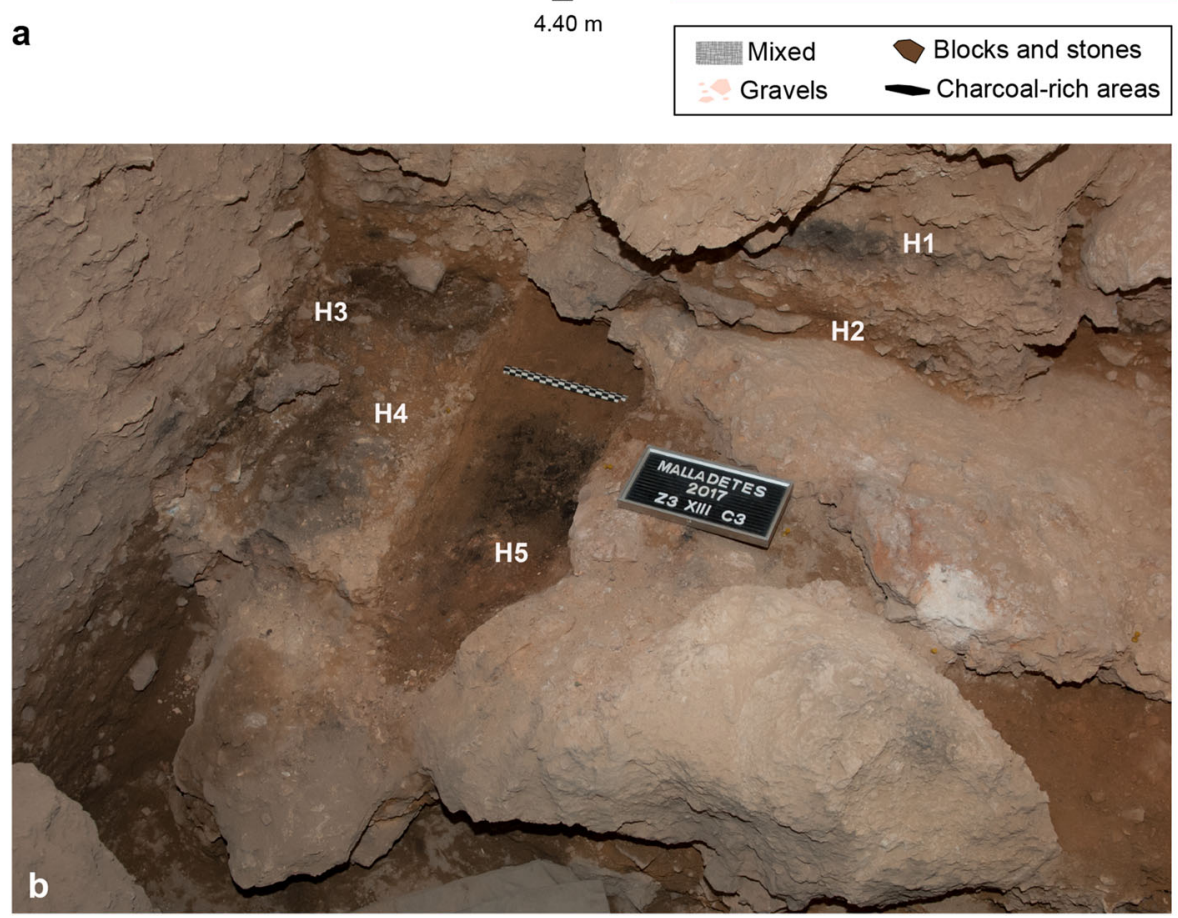

Fig. 3 Stratigraphy of Cova de les Malladetes sector Z-III. a Stratigraphic profile of the 2016-2017 excavations. b Hearths documented from layer XIII (H1, H2, H3, H4 and H5) during the 2016-2017 excavations 


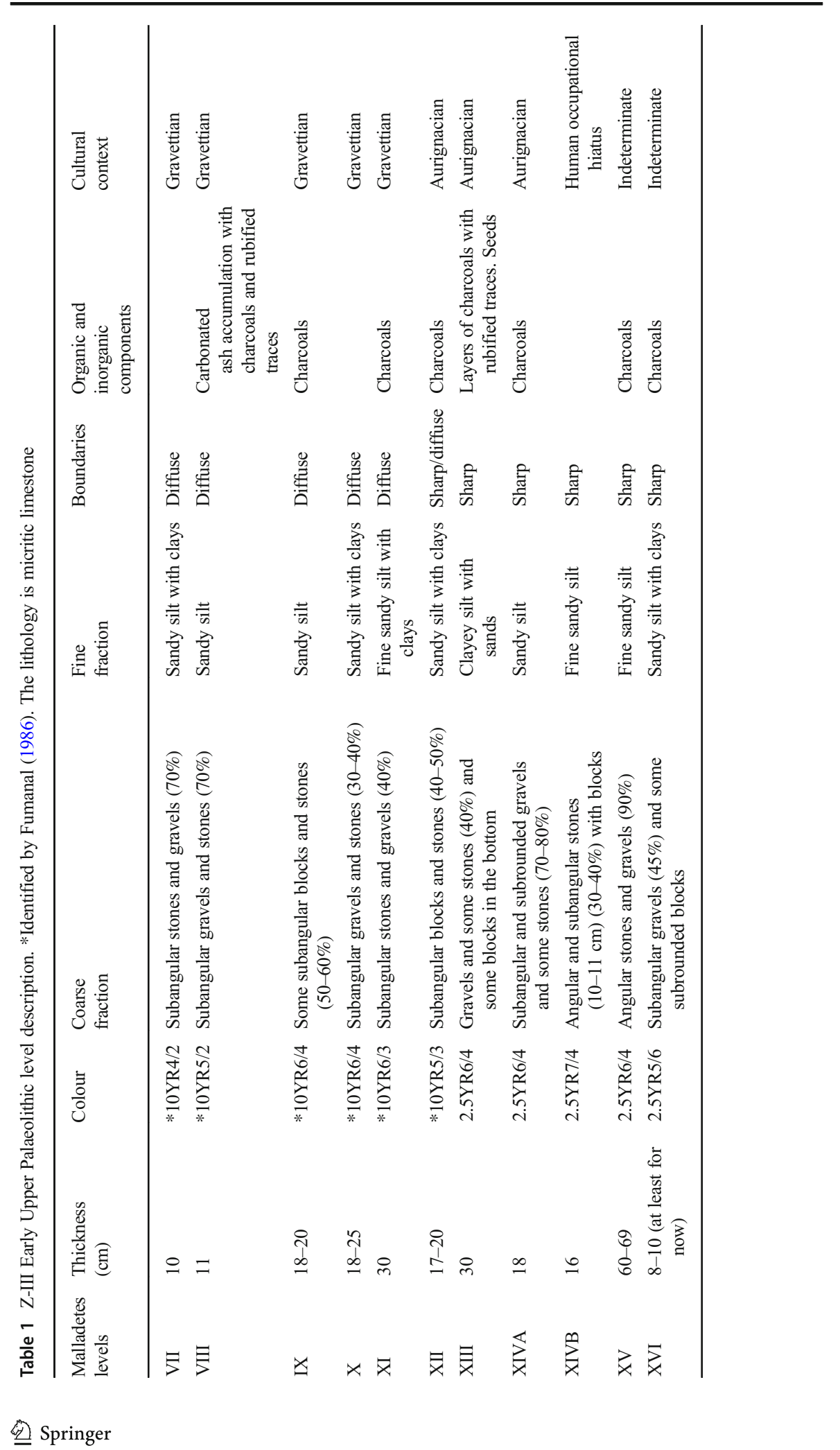


and, more importantly, the different levels excavated in this small area could be dated. The excavation of this test pit (Z-IV) confirmed that the overall thickness of the fill is greater in the central sectors of the rock shelter $(\mathrm{D}, \mathrm{E}, \mathrm{F}, \mathrm{G})$ than in the East and West sectors. This reveals a progressive thinning of the sedimentary packages that was already noticeable in sectors $\mathrm{J}$ and $\mathrm{I}$.

In this study, we focus on the data obtained from sector Z-III (Fig. 1b). The stratigraphical sequence includes levels VII to XVI (Table 1, Fig. 3a), which modifies only the basal levels established in 1976. Level XIV is now divided into two sublevels, and another two new levels are included: XV and XVI.

\section{Materials and Methods}

During the work conducted in 2016 and 2017, the extension of the excavation was determined by various factors: the Upper Palaeolithic levels were preserved in a limited space, which was altered by clandestine interventions, and presented an important compression towards the east, as revealed by previous campaigns. The 2016 campaign started with the recovery of the profile east from the Z-II sector. The excavation followed the stratigraphical units described by Fortea and Jordá (1976) and Fumanal (1986). The thickest units were split into artificial layers. Therefore, down to the base of the 1970 campaign, a strong correlation existed between the stratigraphical units of both interventions (1970 and 2016-2017). Since then, the excavation was adapted to sedimentary changes, also by splitting the units into artificial layers, at least in some cases. Because of the scarcity of archaeological material, the thickness of the artificial layers increased although we still paid attention to the delimitation of the shape of combustion structures. The space, just as in the rest of the sequence, was divided into 14 subsquares of $25 \times 50 \mathrm{~cm}$, and another irregular unit was adjusted to the limit of the southern wall of the cave.

In our excavations (2016-2017), all the sediment was processed with a flotation machine to recover wood charcoal, seeds and microfaunal remains - materials that were hardly documented in the 1970 campaign. Moreover, sedimentary samples were collected from all the levels to study phytoliths, and these were also collected from the hearths for future analyses. These hearth samples and the light fraction of the floated sediment were dry sieved and sorted under a low-power microscope Leica M165C to recover wood charcoal fragments, seeds, leaves and other plant remains. Their taxonomic identification was carried out by referencing fresh material and specialised bibliography with the aid of a Leica DM6000M microscope and a scanning electronic microscope Hitachi S-4100 and Hitachi S-4800 (Servicio Central de Soporte a la Investigación Experimental (SCSIE), Universitat de València).

During the excavation, the recovery of botanical remains had two main goals: (a) to obtain radiocarbon dates on wood charcoal and (b) to obtain samples for archaeobotanical analysis. Charcoal pieces for radiocarbon dating were manually recovered, plotted and assigned to an archaeological reference. Subsequently, their botanical identification was carried out at the Laboratori d'Arqueologia, Universitat de València, and the most appropriate fragments, by weight, degree of conservation and biotic alterations, were selected for radiocarbon dating. 
Taxonomic and anatomical identifications of the macrofaunal and avifaunal remains were made against the reference collection of the Gabinet de Fauna Quaternària Innocenci Sarrión (Museu de Prehistòria de València) and the IVACOR. The number of remains (NR), the number of identified specimens (NISP) and the minimum number of individuals (MNI) (Lyman 1994, 2008) were calculated. Classification of fractures followed Villa and Mahieu (1991) and Real (2017) for the specific classification of morphotypes. To establish the origin of these accumulations, the diagnostic modifications of nonhuman predators (Andrews 1990; Andrews and Evans 1983; Guillem and Martínez Valle 1991; Korth 1979; Laroulandie 2005) and humans have been recorded, and a binocular loupe (Nikon SMZ-10A) was used. Among anthropogenic modifications, lithic marks have been taken into account (Binford 1981; Pérez-Ripoll 1992; Potts and Shipman 1981; Shipman and Rose 1983; Walker and Long 1977) as well as bites (Fernández-Jalvo and Andrews 2011; Laroulandie 2005; Martínez 2009; PérezRipoll 2005; Saladié 2009). The differences between trampling and butchery marks have been established based on their anatomical location and features (Behrensmeyer et al. 1986; Domínguez-Rodrigo et al. 2009). The colour and location of burnt areas were recorded (Nicholson 1993; Stiner et al. 1995). The assessment of postdepositional modifications followed Lyman's procedures (1994).

Regarding the lithic industry, materials recovered in the Z-II sector in 1970 were also included, since a correlation between the two campaigns was possible as a result of the strong correspondence between the definition and nomenclature of the levels, which only vary slightly at the base.

\section{Results}

\section{Hearths from Z-II and Z-III}

Human fires have been found from level XVI to level VIII of Cova de les Malladetes; hearths and products derived from different stages of combustion (torrefied and charred remains and ash) have been identified. During the 1970 campaign, Fortea and Jordá noted the presence of five hearths in the description of the stratigraphic profile of sector Z-II. The identification of some of them as combustion structures was confirmed during the 2016-2017 excavation. A detailed description of hearths is provided in the supplementary online material (Suppl. Material 1: Detailed description of the hearths).

In the Gravettian levels, two hearths were documented: one in level VIII and another in level IX. Both are thick and present a succession of ash and thermally altered stones at the top and a layer of charcoal fragments at the bottom. Moreover, the hearth identified in level IX presents basal sedimentary rubefaction. The Aurignacian levels yielded seven hearths, five of them in level XIII. Samples from the thin hearth of level XII provided a date of 29,690 \pm 560 BP (Fortea and Jordá 1976). Among the five successive combustion structures from level XIII, two stand out: one is lens shaped at the top of the level, measuring approximately $60 \mathrm{~cm}$ in diameter and $4.5 \mathrm{~cm}$ thick (Fig. 4), and another at the base of the level is $6 \mathrm{~cm}$ thick. Most of these Aurignacian hearths present basal sedimentary rubefaction. Finally, in the basal levels, evidence of combustion was detected in the form of a charcoal concentration with basal rubefaction in level XV (Fig. 5(c, d)) and a 

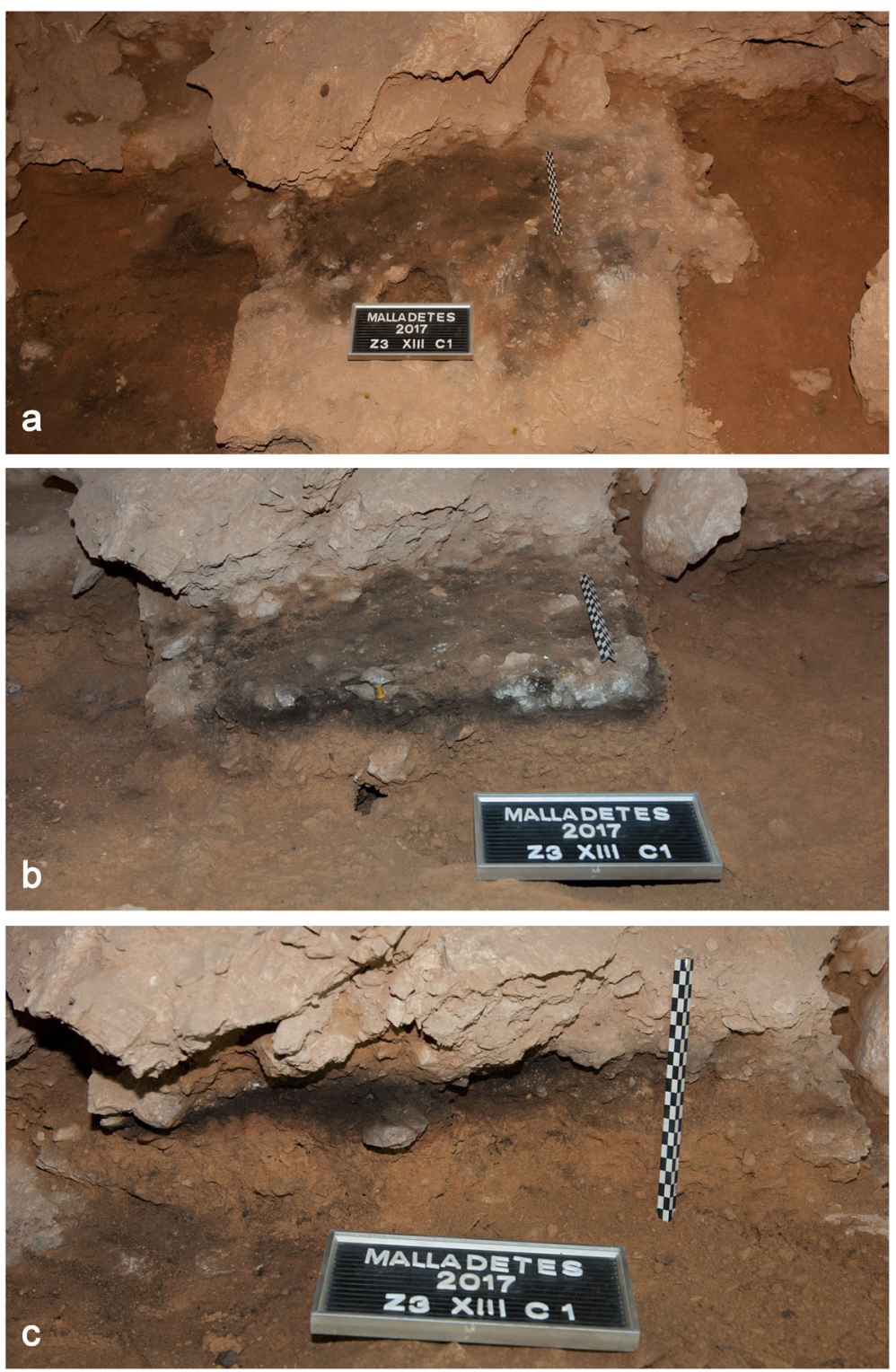

Fig. 4 Hearth (H1) excavation process from level XIII of Cova de les Malladetes. a Upper part of the complete hearth. b Section of the left sagittal part of the hearth. $\mathbf{c}$ Detail of the section conserved in the sagittal profile (rubefaction is visible in the basal part)

hearth of circular shape and measuring about $30 \mathrm{~cm}$ in diameter in level XVI (Fig. $5(\mathrm{a}, \mathrm{b}))$.

The assessment of the combustion structures together with the other features of the archaeological assemblages allows for a better understanding of the human occupation of the Early Upper Palaeolithic levels, as it will be discussed below. 

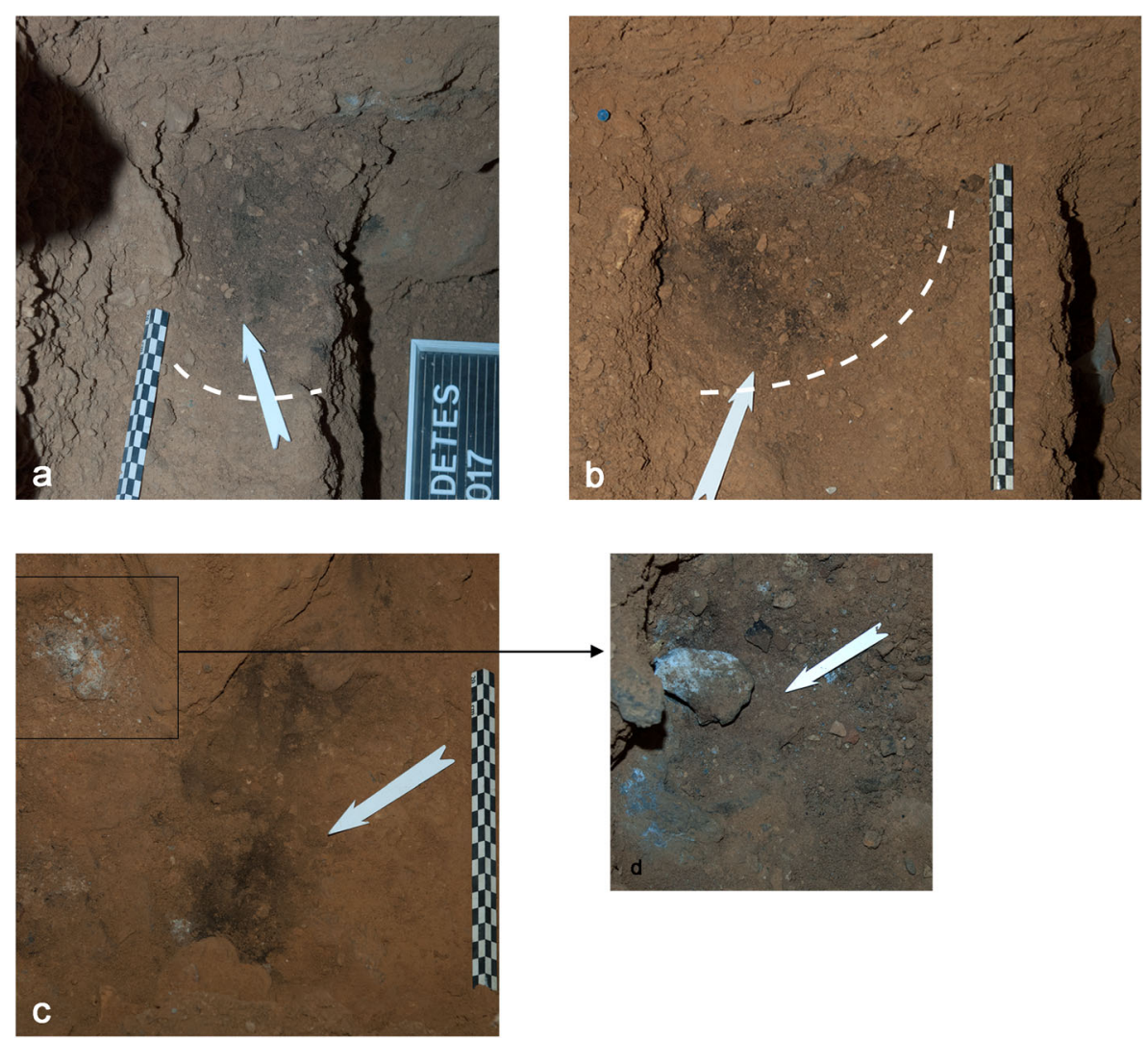

Fig. 5 Hearths of Cova de les Malladetes. $(\mathbf{a}, \mathbf{b})$ Two details of the excavation process of a hearth excavated in level XVI. (c) Excavation process of a hearth from level XV and (d) a detail of a thermo-altered stone inside this hearth, delimited in the excavation process. Arrows indicate the areas with ash concentration and other symptons of rubefaction

Several aspects are noteworthy: level XIII, which contains the largest amount of successive evidence of combustion, with many fire by-products (503 pieces of charcoal and 89 seeds), in some cases affecting different areas of the surface, did not yield a large number of lithic or osseous remains that present evidence of thermal alteration (17 out of 252 remains). However, it should be mentioned that the excavated surface was relatively small: it began with a surface area of $1.50 \mathrm{~m}^{2}$ in layer 1 , followed by $1 \mathrm{~m}^{2}$ in layer 2, because of the presence of a large rocky outcrop in the central area (Fig. 3b). Its size was further reduced in layer 3 because the surface of the rock increased and because of the morphology of the cave wall that limited the distal part of the sector. It seems therefore reasonable that the excavated area may have coincided with a space that was the preferred location for hearths, whereas the areas of activity may have shifted slightly towards the periphery. Moreover, the small size of the excavated area throughout the level has affected the documentation of anthropic evidence. In any case, the good state of hearth preservation and their succession suggest that the occupation processes associated with this level were short-lived and spaced out over time. However, it has not been possible to locate the lithic materials recovered in the 1970 campaign in the collections of the Museu de Prehistòria de València, which makes it 
difficult to assess whether the lower density of remains in level XIII is also true for materials recovered in 1970. Bearing in mind its thickness (somewhat greater than that identified in the excavation and profile from 1970), this level shows a lower density of remains than level XII although there are no great differences in the proportion of burnt bones and anthropogenic marks with respect to the percentages for the previous level.

Concerning the evidence of combustion recorded in levels XV and XVI, this evidence is associated with occupation patterns that can clearly be described as sporadic and very short in duration. In fact, level XIVB marks a turning point in the sequence of the site: no lithic industry, very few faunal remains, no anthropogenic marks or thermal evidence on fauna and almost no charcoal (10 specimens). All this suggests that the origin of level XIVB is not anthropic. Although no lithic industry has been documented in levels XV and XVI (only two chips), human presence is confirmed by the identification of some anthropogenic marks and thermal alterations on bones, in addition to a larger amount of charcoal, mostly from the documented hearths. In any case, remains of nonanthropic origin continue to dominate and show occupation dynamics that alternate between humans and carnivores, with very little evidence of anthropic input. When assessing the archaeological evidence presented in the current work, it is important to mention that levels XV and XVI were only excavated in the 2017 campaign because they are below the depth reached in the 1970 excavation. Moreover, the extent of the excavation was limited to a surface area of $0.80 \mathrm{~m}^{2}$. Therefore, despite the small surface of the studied area, it has been established that humans would have been present at the site during the interval between 44,670 and 39,710 cal BP (for more details, see the 'Radiocarbon Dating' section). This must be carefully assessed by reviewing the materials from the campaigns carried out in the 1940s, paying particular attention to the taphonomic aspects related to the documented fauna.

Finally, concerning the size of hearths, those documented in levels XII to VIII are larger in diameter and thickness, suggesting a more intense use of the occupied space or a longer duration of the occupations with the use of more biomass fuel; this seems obvious for the Gravettian levels, especially levels IX to XI, where the density of lithic, faunal and archaeobotanical remains is greater, the proportion of anthropogenic marks on bones is larger and the evidence of thermal alteration is more frequent. Level XII, which has a lower density of remains and a smaller quantity of anthropogenic marks and thermal evidence, only yielded one hearth in the 1970 campaign, which was thinner than those found in the upper levels.

Table 2 Analysed archaeobotanical remains

\begin{tabular}{|c|c|c|c|c|c|c|c|c|c|c|}
\hline & \multicolumn{3}{|c|}{ Basal levels } & \multicolumn{3}{|c|}{ Aurignacian } & \multicolumn{3}{|c|}{ Gravettian } & \multirow[t]{2}{*}{ Total } \\
\hline & XVI & XV & XIVB & XIVA & XIII & XII & XI & $\mathrm{X}$ & IX & \\
\hline No. of samples & 5 & 10 & 2 & 17 & 34 & 15 & 66 & 32 & 25 & 206 \\
\hline No. of wood charcoal fragments analysed & 77 & 86 & 10 & 469 & 503 & 209 & 486 & 20 & 121 & 1981 \\
\hline No. of taxa (charcoals) & 1 & 2 & 3 & 1 & 5 & 6 & 3 & 1 & 4 & - \\
\hline No. of seeds & 1 & 1 & 1 & 5 & 89 & 3 & 15 & 6 & 10 & 131 \\
\hline No. of taxa (seeds) & 1 & 1 & 1 & 4 & 8 & 2 & 9 & 2 & 6 & - \\
\hline
\end{tabular}




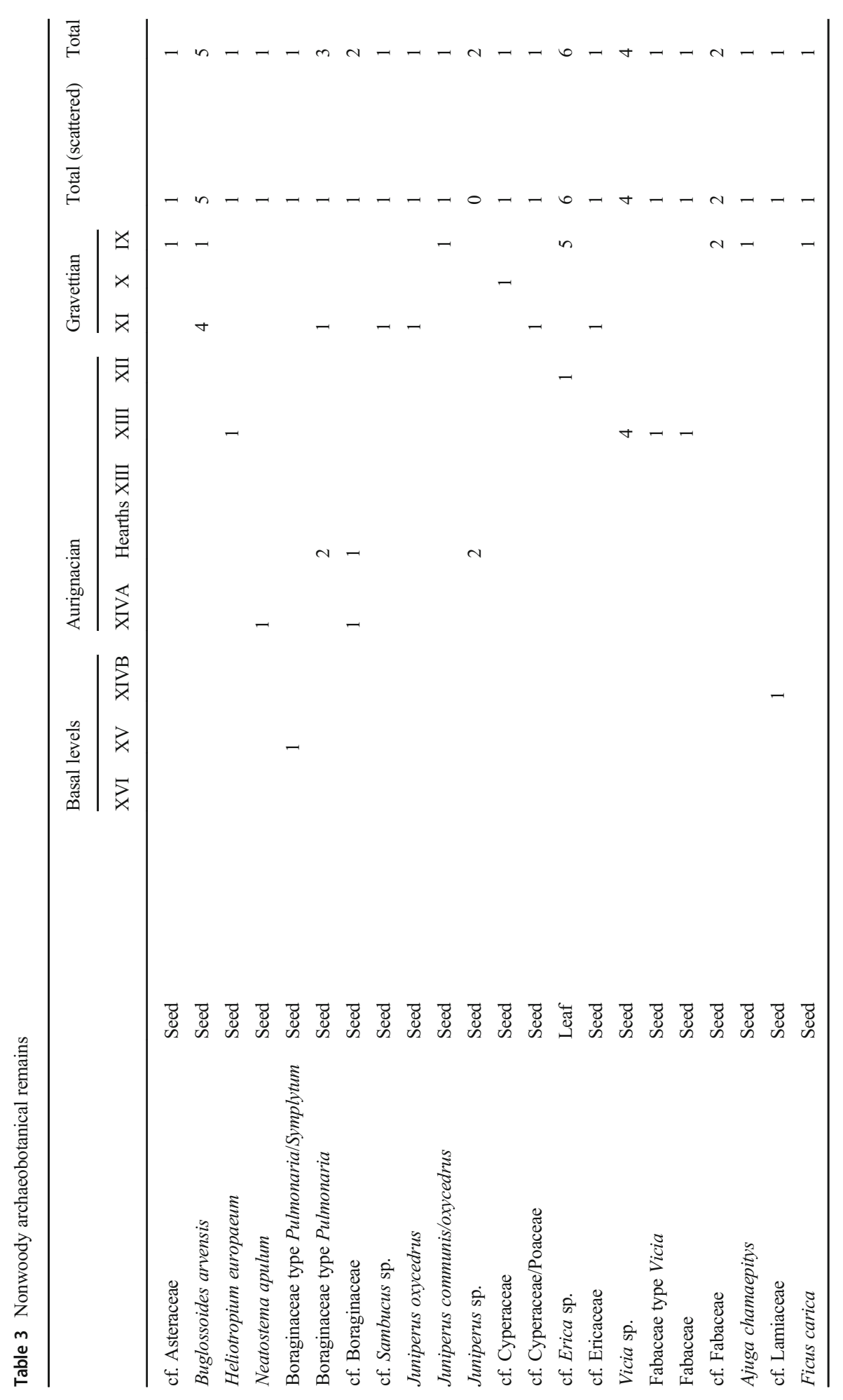




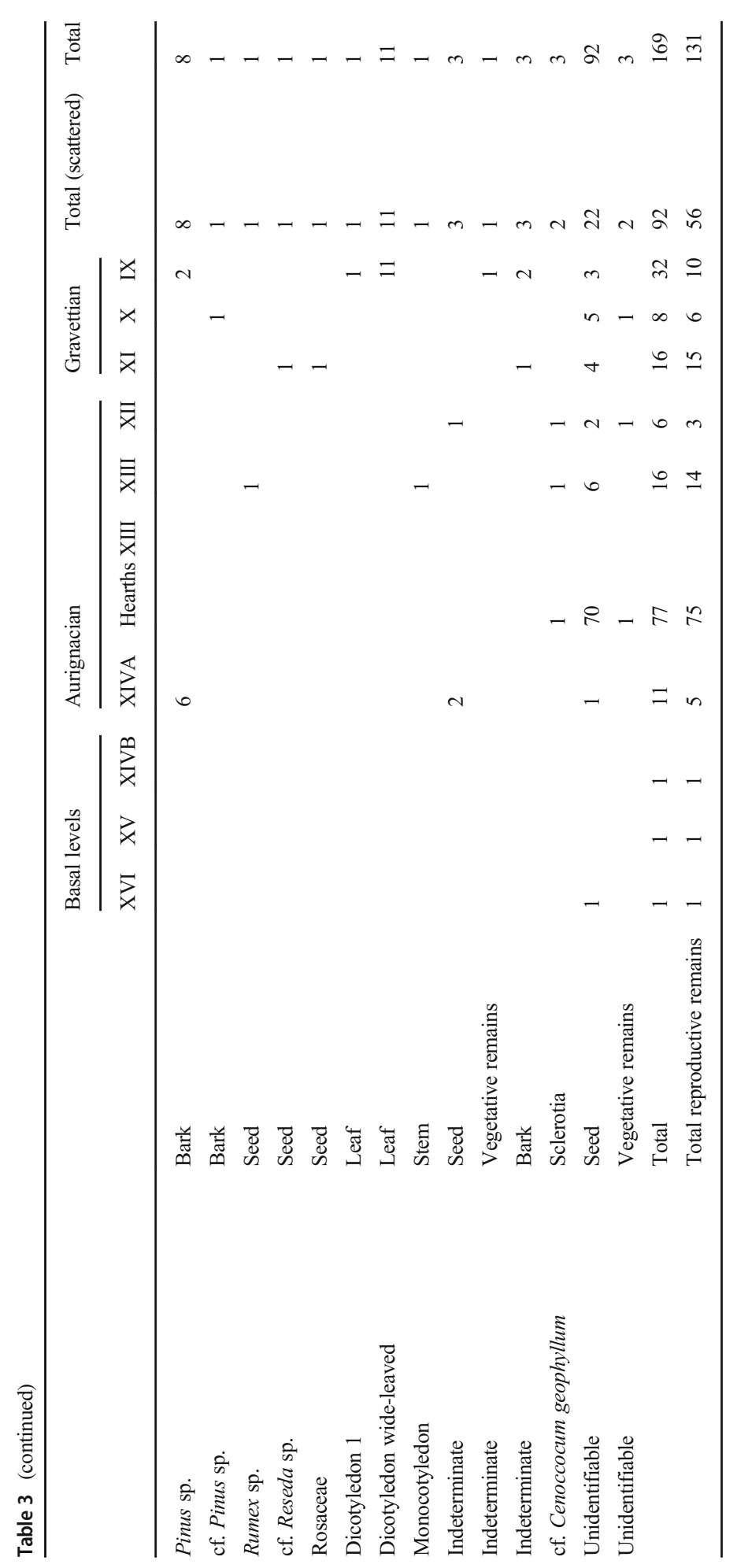



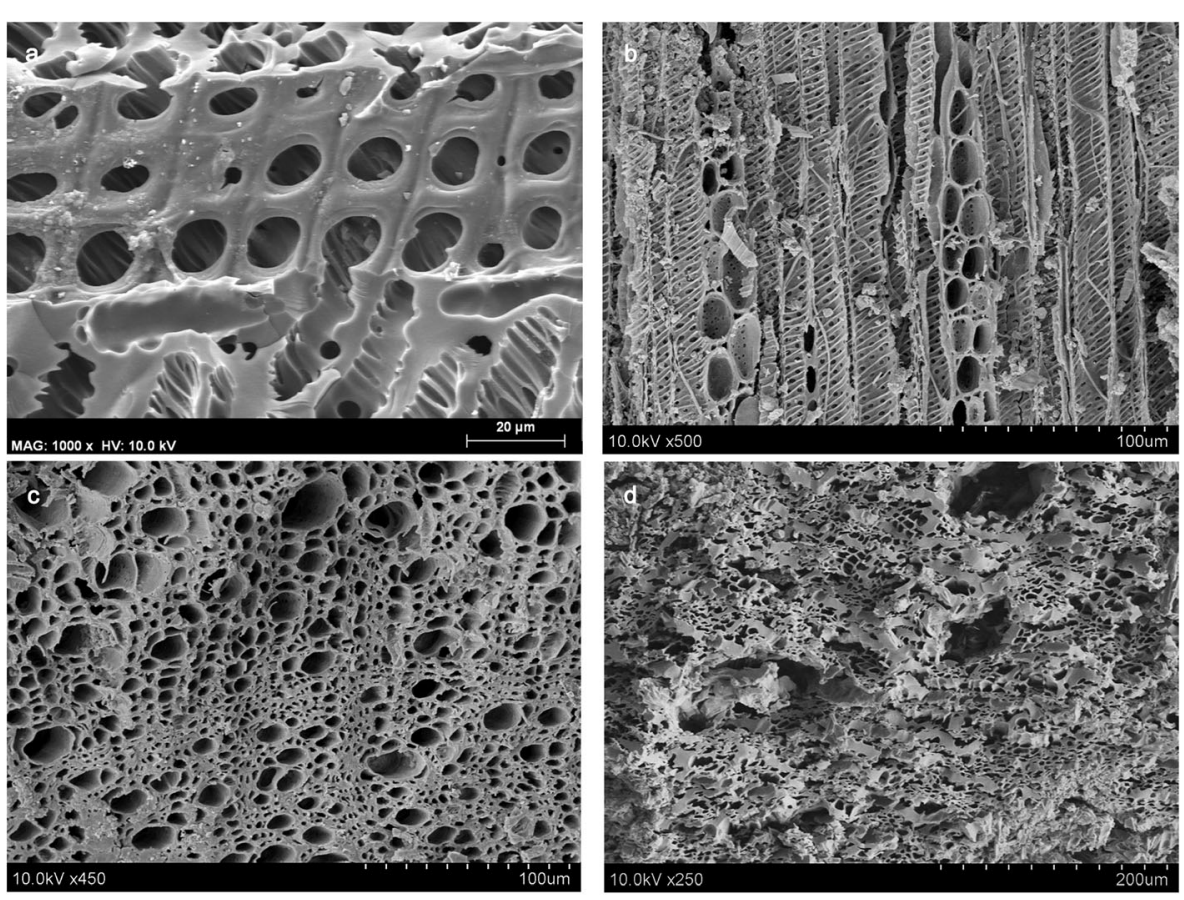

e
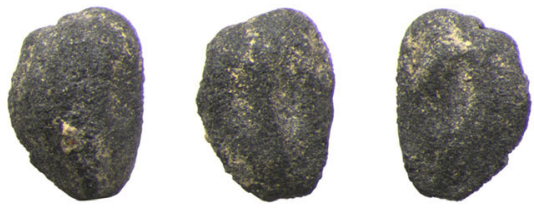

$1 \mathrm{~mm}$

g
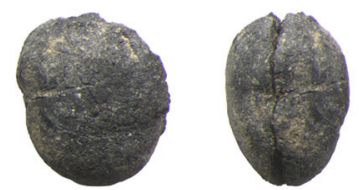

$2 \mathrm{~mm}$ h

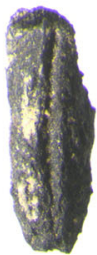

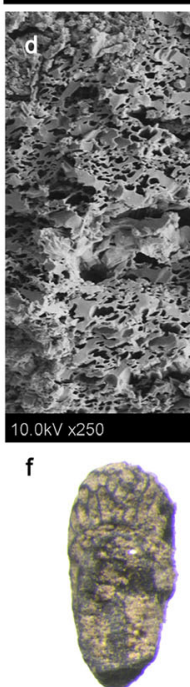

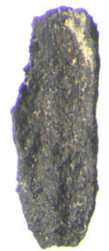

$1 \mathrm{~mm}$
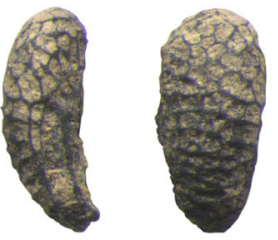

$1 \mathrm{~mm}$
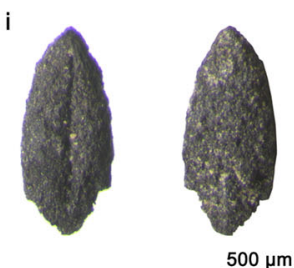

Fig. 6 Archaeobotanical remains from Cova de les Malladetes. a Pinus nigra/sylvestris wood charcoal (radial section) (level XI). b Fabaceae wood charcoal (tangential section) (level XII). c Cistaceae wood charcoal (transversal section) (level XII). d Angiosperm wood charcoal (transversal section) (level XII). e Juniperus oxycedrus seed (level XI). f Ajuga chamaepitys seed (level IX). g Fabaceae seed (level XIII). h Erica sp. leaf (level IX). i Dicotyledon leaf (level IX)

\section{Archaeobotanical Analysis}

From level IX to level XVI, 198 samples (Table 2) unevenly distributed among the different archaeological layers and levels, together with eight samples from combustion structures, were analysed. Wood charcoal remains were present in most of the samples in dissimilar amounts and sizes, and even though a few pieces were bigger than $2 \mathrm{~mm}$, 
these were quite scarce in the hearth samples. A total of 1981 wood charcoal fragments from one square metre (Z-III) were analysed. Data presented here are preliminary because analyses are ongoing. Some layers have not been analysed yet. In addition, some uncharred wood fragments were preserved, probably because of their mineralisation. Together with these woody remains, charred bark fragments were also recovered. Reproductive remains were extremely scarce along the sequence: just 131 seeds were preserved. Some leaves and shell fragments were also documented.

Regarding the reproductive remains (Table 3, Fig. 6), Aurignacian level XIII is the richest of the sequence, with 14 scattered remains and 75 from hearth samples. This is followed by Gravettian levels IX and XI with 10 and 15 remains, respectively. In contrast, the lower levels provided a few carpological elements. Although the number of remains (NR) is low, the diversity should be noted: a minimum of 17 species was documented. The number of carpological remains documented in the hearth samples of level XIII stands out. However, these remains are fragmented, making their taxonomical identification challenging. On the other hand, the combustion structure from level XIVA did not provide any seed results.

Among the documented taxa, some stand out, such as Buglossoides arvensis (field gromwell), Vicia sp. (vetch), Boraginaceae type Pulmonaria (lungwort) and Juniperus oxycedrus (cade juniper). The rest of the taxa provides one specimen, but the presence of a seed of Ficus carica (fig), a fruit of Ajuga chamaepitys (ground-pine), a fragmented seed of cf. Sambucus sp. (elder), an achene of cf. Cyperaceae (sedges) and a pinecone scale fragment stand out. Some shell fragments were recovered, but their degree of fragmentation prevents their taxonomical identification.

Concerning charred leaves, most have been identified as a dicotyledon of wide leaves. Six fragments were classified as cf. Erica sp. (heath), and one remain is from a dicotyledon of needle-like leaves. A fragment of a pine needle was documented in level XI. In addition, 12 bark fragments were recovered along the sequence, mainly in levels IX and XIVA, with eight of them belonging to Pinus sp. (pine) and three to an indeterminate taxon.

The wood charcoal assemblage shows an extremely homogeneous taxonomic composition throughout the sequence, with a clear dominance of Pinus nigra/sylvestris (black pine/scots pine), providing almost 100\% of the remains in all the levels (Fig. 7). Here, 1962 out of the 2006 analysed pieces of wood charcoal were identified as pines. Angiosperm charcoals frequently present intense alterations in their anatomical structure; therefore, 23 remains were classified into the angiosperm range. The identified angiosperms formed part of the heliophilous shrubland: Fabaceae (legume family), Erica sp. (heath) and Cistaceae (rock rose family) (Fig. 6). A piece of a monocotyledon was also documented.

\section{Micromammal Analysis}

Ten micromammal species have been identified in Malladetes: two insectivores, Crocidura suaveolens and Talpa occidentalis; three chiropterans, Rhinolophus hipposideros, Myotis bechsteinii and Pipistrellus kuhlii; and five species of rodent, Iberomys cabrerae, Microtus arvalis, Terricola duodecimcostatus, Apodemus sylvaticus and Eliomys quercinus. Considering their palaeoambiental implications, three species have been selected for a more detailed commentary: Crocidura 


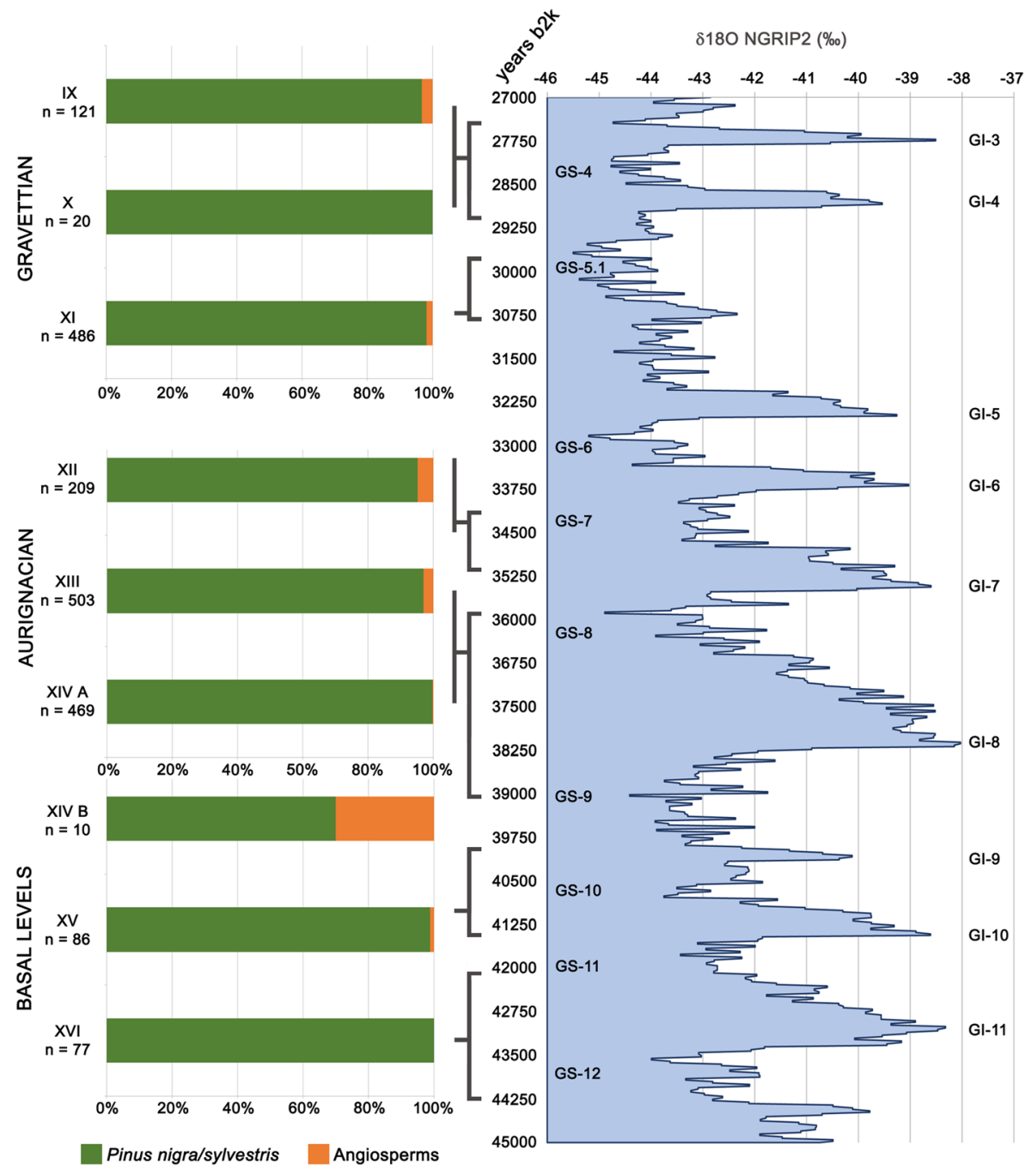

Fig. 7 Wood charcoal analysis results of Cova de les Malladetes. Evolution of the ratio Pinus nigra or P. sylvestris/angiosperms correlated with the events and values of $\delta^{18} \mathrm{O}$ de NGRIP2. After Rasmussen et al. (2014) and Seierstad et al. (2014)

suaveolens, Talpa occidentalis and Microtus arvalis (Table 4). In addition, we include a taphonomic study of bone assemblage because doing so can provide substantial information on the origin of the remains.

Regarding the genus Crocidura (Fig. 8a, c, Suppl. Material 2 Table 1: Measure of micromammal remains), there are two species in the Iberian Peninsula: C. russula and C. suaveolens. It is not always easy to isolate these two species based on their molar morphology. However, Poitevin (1984) described the constricted labial cingulum of the lower second molars (m2) as a diagnostic feature of Crocidura russula. The lower $\mathrm{m} 2$ of Malladetes have a nonconstricted cingulum (Fig. 8c). For other researchers (Rey and Landin 1973), the morphological differences between the two species are much more visible in the upper fourth premolars (P4), but no P4 has been preserved at Malladetes. 
Table 4 Taxonomical spectrum of micromammals

\begin{tabular}{|c|c|c|c|c|c|c|c|c|c|c|c|c|}
\hline & \multicolumn{6}{|c|}{ Basal levels } & \multicolumn{6}{|c|}{ Aurignacian } \\
\hline & \multicolumn{2}{|c|}{ XVI } & \multicolumn{2}{|l|}{ XV } & \multicolumn{2}{|c|}{ XIVB } & \multicolumn{2}{|c|}{ XIVA } & \multicolumn{2}{|l|}{ XIII } & \multicolumn{2}{|l|}{ XII } \\
\hline & $N$ & $\%$ & $N$ & $\%$ & $N$ & $\%$ & $N$ & $\%$ & $N$ & $\%$ & $N$ & $\%$ \\
\hline T. occidentalis & & & 1 & 2.564 & 2 & 3.571 & & & & & & \\
\hline C. suaveolens & 1 & 2.703 & 2 & 5.128 & 1 & 1.786 & 2 & 1.835 & & & & \\
\hline R. hipposideros & & & & & & & 1 & 0.917 & & & & \\
\hline M. bechsteini & & & & & & & 1 & 0.917 & & & & \\
\hline P. kuhlii & & & & & & & 1 & 0.917 & & & & \\
\hline Quiroptera sp. & & & 1 & 2.564 & & & & & & & & \\
\hline M. cabrerae & 4 & 10.811 & 1 & 2.564 & 11 & 19.643 & 12 & 11.009 & 13 & 10.32 & 11 & 11.43 \\
\hline M. arvalis & & & & & & & 1 & 0.917 & & & & \\
\hline T. duodecimcostatus & 10 & 27.027 & 7 & 17.949 & 9 & 16.071 & 14 & 12.844 & 29 & 23.02 & 10 & 28.57 \\
\hline A. sylvaticus & 19 & 51.351 & 20 & 51.282 & 24 & 42.857 & 66 & 60.550 & 66 & 52.38 & 16 & 45.71 \\
\hline E. quercinus & 3 & 8.108 & 7 & 17.949 & 9 & 16.071 & 11 & 10.092 & 18 & 14.29 & & \\
\hline Total & 37 & & 39 & & 56 & & 109 & & 126 & & 35 & \\
\hline
\end{tabular}

The morphology of the ascending branch of the mandible is diagnostic and helps to definitively distinguish C. russula from C. suaveolens (López-García 2008). In the lingual view of the mandibles found at Malladetes, the mandibular branch is slender, and the coronoid apophysis is angled slightly towards the posterior part of the mandible (Fig. 8a, c). The internal temporal fossa is ovoid, the distal part is very slender and the junction between the coronoid spicule and the articular condyle forms a $90^{\circ}$ angle. Likewise, from the posterior view, the interarticular area of the condyle shows a concavity towards the labial part of the mandible that does not exist in C. russula (Fig. 8a, c). Additionally, the measurements of the height of the coronoid process of the mandible of the only two specimens studied clearly separate the two species, meaning that the remains found at Malladetes can be attributed to C. suaveolens (Suppl. Material 2 Table 1: Measure of micromammal remains).

In the Iberian Peninsula, $C$. suaveolens occupies a great diversity of ecological niches in the Atlantic area, yet it is relegated to humid environments in the Mediterranean area (Rey 2007). However, a recent study has shown the development of a biological process of competitive exclusion that has clearly contributed to the distribution and phylogeography of $C$. russula since it arrived in the Iberian Peninsula (Biedma et al. 2018).

Talpa occidentalis is represented in Malladetes sequence by 13 humeri (Fig. 8d) (Suppl. Material 2 Table 1: Measure of micromammal remains). We have considered the width of the humeral diaphysis as a diagnostic element in the species identification (López-García 2008) (Fig. 8d). The Spanish mole (Talpa occidentalis) is endemic to the Iberian Peninsula and is distributed more or less continuously throughout the northwest third of the peninsula but is not present in the Pyrenees and the Ebro River basin. In the rest of the peninsula, it is restricted to mountainous areas. In terms of 


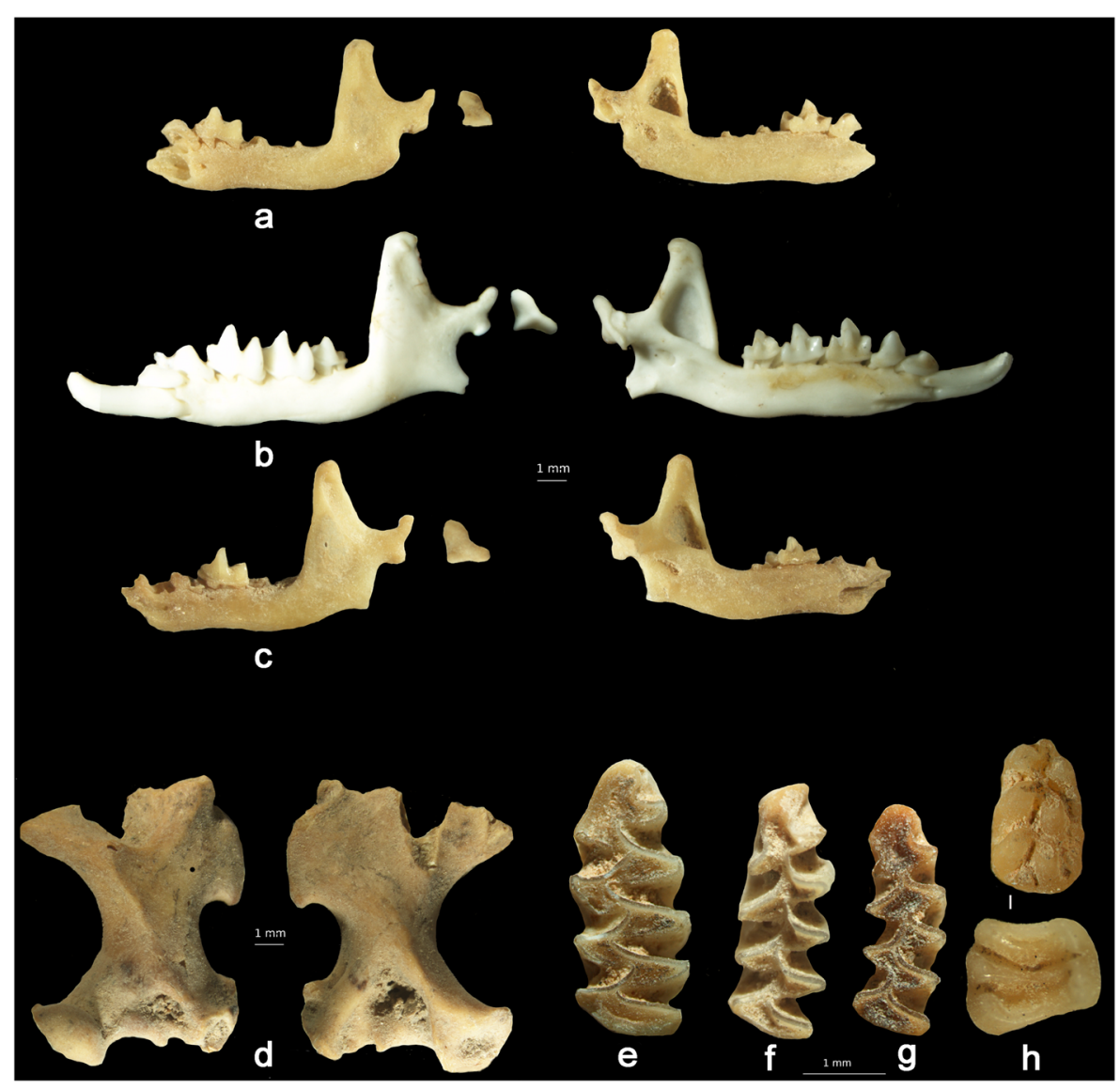

Fig. 8 Micromammals of Cova de les Malladetes. a Left mandible of Crocidura suaveolens from Malladetes. b Left mandible of an actual Crocidura russula. c Left mandible of Crocidura suaveolens from Malladetes. d Left humerus of Talpa occidentalis. e Lower left $\mathrm{m} 1$ of Microtus cabrerae. f Lower left $\mathrm{m} 1$ of Microtus arvalis. g Lower left $\mathrm{m} 1$ of Terricola duodecimcostatus. h Lower left $\mathrm{m} 1$ of Eliomys quercinus. i Lower right $\mathrm{m} 1$ of Apodemus sylvaticus

habitat, the requirements of the Spanish mole are similar to those of the European mole: soft soils and abundant prey. It thrives from sea level up to $2300 \mathrm{~m}$ in the Sierra Nevada (Román 2007).

Microtus arvalis (common vole) is documented by one m1 (Suppl. Material 2 Table 1: Measure of micromammal remains). Microtus arvalis has an $\mathrm{m} 1$ with a very similar morphology to that of Microtus agrestis; however, the $\mathrm{m} 1$ of $M$. arvalis differs from the $\mathrm{m} 1$ of $M$. agrestis by the almost symmetrical and parallel arrangement of T4/ $\mathrm{T} 5$, especially $\mathrm{T} 6 / \mathrm{T} 7$, in addition to the corresponding re-entrant angles, giving the anteroconid complex (ACC) a rounded shape in contrast to the angular shape of M. agrestis (Cuenca-Bescós et al. 2008). The morphometric analysis of the shortest width or distance between LRA5 (lingual re-entrant angle 5) and BRA4 (buccal reentrant angle 4), here identified with the letter ' $d$ ', again shows the morphological difference between these two taxa. In fact, although some of the measurements of these two species overlap, the width ' $d$ ' is greater in the Microtus arvalis specimens (most 
values are above $0.2 \mathrm{~mm}$ ) (Suppl. Material 2 Table 1: Measure of micromammal remains), which allows for a rounded anteroconid (AC) to develop. Moreover, the ratio between the average Li (lingual width on T5) and La (labial width on T3) shows that Microtus agrestis specimens are more asymmetric than Microtus arvalis (LópezGarcía 2008). Therefore, we can affirm that the $\mathrm{ml}$ of Malladetes studied here is from M. arvalis.

Until 20 years ago, the distribution of $M$. arvalis was limited to the mountain systems of the northern half of the Iberian Peninsula (Cantabrian Mountains, Central System, Iberian System and the Pyrenees). Nowadays, it occupies almost all of the Northern Plateau of Spain (González-Esteban and Villate 2007). In the Valencian region, it inhabits the oro- and supra-Mediterranean bioclimatic zones of the Penyagolosa Massif (Jiménez et al. 1989) and Ademuz, and it is sporadically found in the highland areas of the Utiel-Requena region (Jiménez et al. 2012).

Regarding the taphonomic analysis, we have tried to identify the responsible agents for the micromammal accumulations in Malladetes. We started from the hypothesis that the main responsible agents would be the species that cover their trophic needs from consuming small vertebrates, such as owls, eagles or other carnivores. In fact, many of the bones present the characteristic features of digestion (Suppl. Material 3 Table 2: Index of digestion on the micromammals consumed). However, another possibility is that human groups could also be responsible for the accumulation of some of the small mammal remains.

Based on a principal component analysis, the main agents behind the accumulation in levels XII and XV were found to be the predators of group 1: Athene noctuaApodemus (9), Athene noctua-Suncus (10), Tyto alba-Apodemus (4), Tyto albaCrocidura (5), Bubo bubo-Erinaceus (6) and Bubo bubo-Oryctolagus (7). This group is characterised by low percentages of alterations and the digestion of molars and

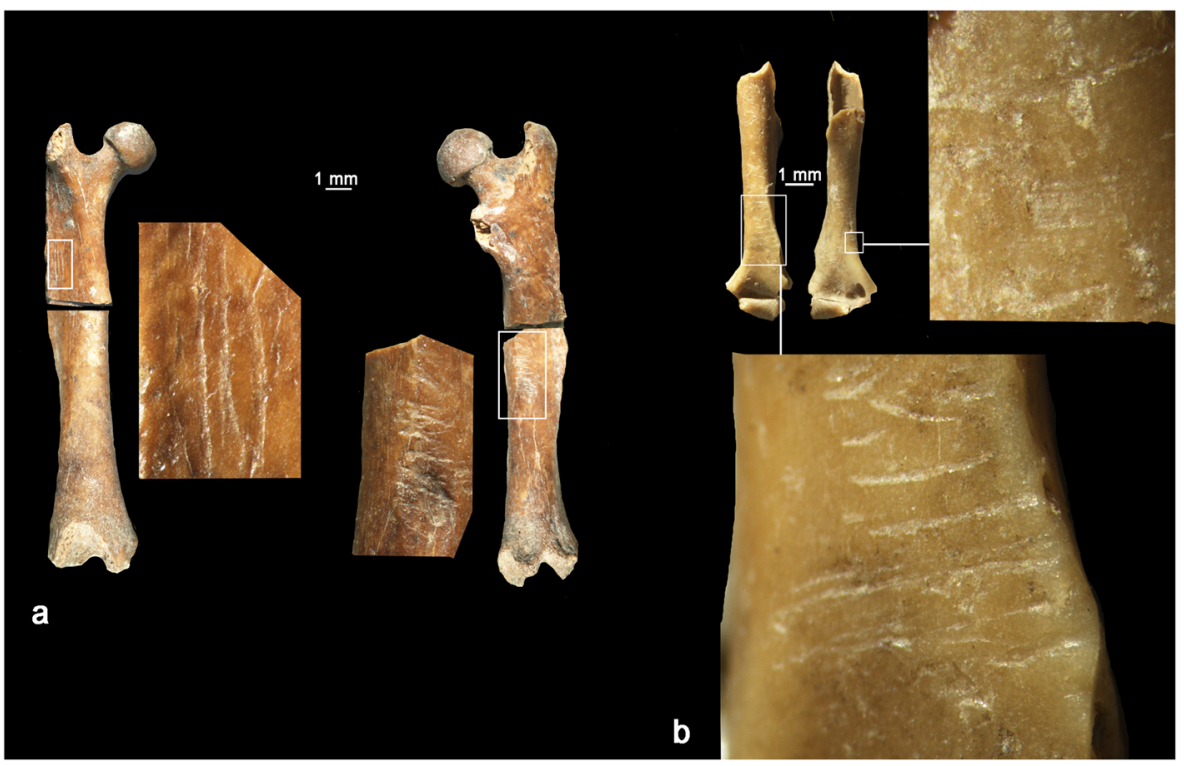

Fig. 9 Modifications on micromammal bones of Cova de les Malladetes. a Right femur of M. cabrerae. b Left humerus of E. quercinus 
incisors. However, in levels XIVA, XIVB and XVI, according to the values of digestion indexes, these remains are better classified into group 2: Strix alucoApodemus (11), B. bubo-Rattus (8), Asio otus-Apodemus (13) and Asio otus-Crocidura (14). In level XIII, the carnivores would have actively participated in the accumulation of micromammal remains (Suppl. Material 4 Fig. 1: Principal Component Analysis of Malladetes micromammals). The high number of micromammal bones is consistent with the scarce anthropic presence at these levels.

Some modifications required a deeper analysis to clarify if their origin could correspond to human activities. Hence, we present a brief description of two remains from level XIVA. First, a right femur of Microtus cabrerae preserves marks that are grouped around the third trochanter. In the posterior view, there are several longitudinal deep crossing grooves along the diaphysis, forming a 'U' section (Fig. 9a). From the anterior view, the marks have a perpendicular disposition regarding the diaphysis (Fig. $9 \mathrm{~b}$ ) and a morphology similar to those described above. The second bone corresponds to a left humerus of Eliomys quercinus (Fig. 9), in which the marks go through the entire diaphysis and again have a deep ' $U$ ' section that sometimes is reduced to superficial scrapes. These types of marks could correspond to those left by human teeth on the bone surfaces of very small animals, such as leporids or birds. However, considering the marks are located on two very small-sized bones and that there are also

Table 5 Faunal remains. Taxonomic composition (NISP) by level

\begin{tabular}{|c|c|c|c|c|c|c|c|c|c|}
\hline & \multicolumn{3}{|c|}{ Basal levels } & \multicolumn{3}{|c|}{ Aurignacian } & \multicolumn{3}{|c|}{ Gravettian } \\
\hline & XVI & $\mathrm{XV}$ & XIVB & XIVA & XIII & XII & $\mathrm{XI}$ & $\mathrm{X}$ & IX \\
\hline Perissodactyla & 3 & & & & & & 2 & 2 & \\
\hline Equidae & 3 & & & & & & 2 & 2 & \\
\hline Artiodactyla & 15 & 10 & 1 & 11 & 14 & 11 & 89 & 36 & 23 \\
\hline Caprinae & 9 & 10 & 1 & 6 & 2 & 6 & 63 & 24 & 8 \\
\hline Capreolus & & & & & & & 1 & & \\
\hline Cervus & 5 & & & 5 & 12 & 5 & 23 & 12 & 13 \\
\hline Sus & & & & & & & 2 & & 2 \\
\hline Bos & 1 & & & & & & & & \\
\hline Leporidae & 25 & 28 & 14 & 135 & 150 & 12 & 146 & 147 & 11 \\
\hline Carnivora & & 1 & & & & & & & \\
\hline Lynx & & 1 & & & & & & & \\
\hline Indeterminate (by size) & 113 & 20 & $\mathbf{0}$ & 30 & 88 & 37 & 512 & 477 & 349 \\
\hline Large size & 2 & & & & & 2 & & & 1 \\
\hline Medium/large size & 2 & 2 & & & & & 4 & & \\
\hline Medium size & 94 & 9 & & 9 & 29 & 16 & 292 & 99 & 29 \\
\hline Small/medium size & 1 & 8 & & 5 & 17 & 18 & 54 & 40 & 6 \\
\hline Very small size & & & & 14 & 35 & 1 & 46 & 9 & 5 \\
\hline \multirow[t]{2}{*}{ Indeterminate } & 14 & 1 & & 2 & 7 & & 116 & 329 & 308 \\
\hline & 156 & 59 & 15 & 176 & 252 & 60 & 749 & 662 & 383 \\
\hline
\end{tabular}

The bold entries in the forst column reflect the "Order" of the animals, containting different families or species 
nonanthropogenic modifications over the rest of the micromammal assemblage, we are cautious, for now, and can only contemplate the possibility that human groups may have consumed this type of prey. We are preparing a specific study on this subject.

\section{Macromammal Analysis}

We have analysed a total of 2512 faunal remains. In the basal levels, there are 230 faunal remains: XIVB (15), XV (59) and XVI (156). Here, 100\% (XIVB), 66.1\% (XV) and $27.6 \%$ (XVI) of the bones were taxonomically identified. Species of ungulates (in order of importance: caprine, red deer, bovine and equids), leporids and lynx were documented. Leporidae is the most important species according to the \% NISP (Table 5).

The level of fragmentation of the remains is $53.3 \%$ (XIVB), 93.2\% (XV) and $94.9 \%$ (XVI). Fractures occur mainly on fresh bone, while diagenetic ones are very scarce. As for the origin of the accumulations, in level XIVB, the leporid remains present nonanthropogenic modifications (mostly digested bones). In level XV, carnivore bites appear on caprine bones; the leporid remains are related to nonanthropogenic modifications although it has not been possible to determine whether they were caused by raptors or small carnivores; a lynx bone shows lithic incisions, along with toothmarks from carnivores and rodents. In level XVI, various anthropogenic modifications are found, such as incisions on long bones and ribs of medium- and large-sized prey. A rib fragment shows overlapping lithic incisions and carnivore bites that seem to indicate primary access by humans. The carnivore marks (bites and digestion) appear on caprine and medium- and large-sized prey. Some leporid remains are related to the activity of birds of prey (beak impacts and digested bones). Only one caprine bone (XV) and three of the medium-sized bones (XVI) have been affected by fire.

Concerning the EUP levels (IX-XIVA), the total faunal assemblage is composed of 2282 remains: 488 bones (21.4\%) from the Aurignacian levels and 1794 (78.6\%) from the Gravettian levels (Table 5). In the Aurignacian sample, most of the remains were found in levels XIII (252) and XIVA (176), with lower quantities found in XII (60). In the Gravettian sample, levels XI (749) and X (662) feature a higher proportion of materials than level IX (383). Overall, the percentage of taxonomically identified remains decreases from the bottom to the top of the sequence: $82.9 \%$ (XIVA), $65.1 \%$ (XIII), $38.3 \%$ (XII), $31.6 \%$ (XI), $27.9 \%$ (X) and $8.4 \%$ (IX). This pattern is also reflected in the leporid representation.

The fragmentation level is very high, yet the percentage of complete bones is slightly higher in the Aurignacian (14.9\%) than in the Gravettian (3.9\%). These higher values could be a consequence of the alteration made by different agents and the postdepositional processes, mainly concretions and chemical corrosion, which affect more than $90 \%$ of bones in both periods.

If we compare this assemblage with the fauna from the 1940s excavations (ongoing study), there are relevant differences that seem to be related to the location of the excavation areas and the presence of carnivore activities. In the most open shelter area, where the most recent excavation took place (Fig. 1b), the number of carnivore remains is very scarce, while in the most protected cave area (1940s excavations), where several carnivore bones have been found, the material shows better conservation and lower fragmentation. 
Leporidae, Caprinae and Cervus were identified in the Aurignacian levels, with a better representation of leporids. In the Gravettian sample, these taxa show the highest values, but there are some differences: Leporidae is the best-represented group in levels $\mathrm{XI}$ and X but not in IX, where Cervus stands out. The Cervus and Caprinae quantities are more important in the Gravettian, where there is also a greater taxonomic diversity with the presence of other taxa such as Capreolus, Equidae and Sus.

Regarding the origin of the accumulations (Fig. 10), in the case of Leporidae, the Aurignacian sample results mainly from nonanthropic agents, with modifications that could be related to raptors and small carnivore activities. On the other hand, in the Gravettian, evidence of human processing and consuming activities is more abundant although there are bones accumulated by other predators as well. The anatomical representation of leporids indicates a whole transport to the site in both periods but with a predominance of the hindlimb. There is, however, a higher percentage of axial elements in the Aurignacian that could be related to nonhuman activities. The articular fusion of the three main long bones (humerus, femur and tibia) indicates the presence of adult and immature individuals in both periods, but the number of immatures $(60 \%)$ increases in the Gravettian at the expense of the adult remains (40\%). The fragmentation level is similar for both periods (77-67.1\%).

The Cervus sample has an anthropic origin in both phases, as shown by the different modifications: fresh fractures, percussion notches and cut marks (Suppl. Material 5 Table 3: Faunal remains. Anthropogenic and nonanthropogenic modifications). The anatomical representation is balanced in the Gravettian, except for the lack of the axial skeleton. In the Aurignacian, however, there could be a selective transport of the hindlimb and the cranial part of the prey. The caprine remains in both phases could be the result of anthropic and carnivore activities. Fresh fractures, percussion notches and cut marks in greater quantities were identified in the Gravettian. On the other hand, there were also several modifications related to carnivore actions. The anatomical representation is balanced in the Gravettian, with a lower percentage among the axial elements. However, the cranial elements are abundant in the Aurignacian, as well as some limb bones, but axial, phalanges and metapodials were not recorded. The ungulate assemblage has a high degree of fragmentation throughout the studied sequence: Cervus $(90.5-80 \%)$ and Caprinae (92.3-84\%), adding to the great amount of indeterminate and fragmented remains that could correspond to those taxa. The indeterminate remains of medium- and small-sized prey show more frequently nonanthropogenic modifications in the Aurignacian, while the anthropogenic modifications are more abundant in the Gravettian.

\section{Avifauna Analysis}

Fifty-six bone remains of birds have been analysed (Suppl. Material 6 Table 4: Taxonomic identification of bird remains), with a higher concentration found in level XIVA. The identification rate is high ( $73.2 \%$ of the total), corresponding to a sample with few fractured remains and a shortage of small-sized fragments.

The basal levels from XVI to XIVB present very few identifiable remains. The Aurignacian level XIVA has a greater abundance of species, mainly of red-legged partridge (Alectoris rufa), the chough (Pyrrhocorax pyrrhocorax) and the rock dove 


\section{PREY}

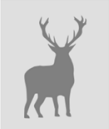

a
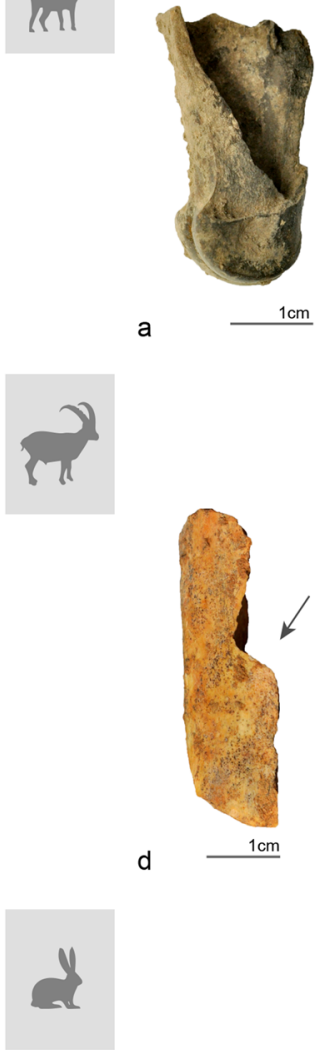

g

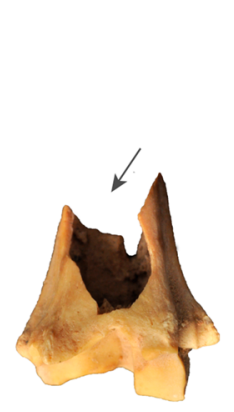

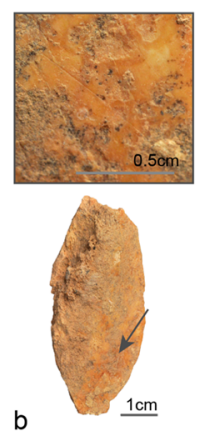
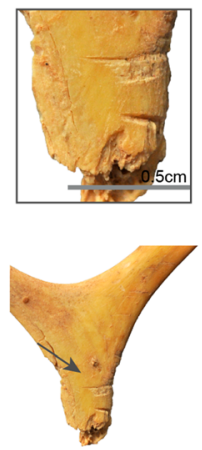

e
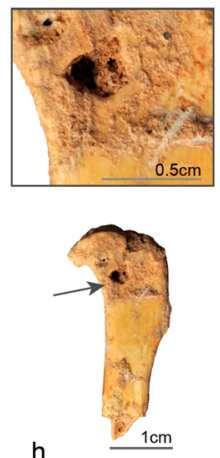
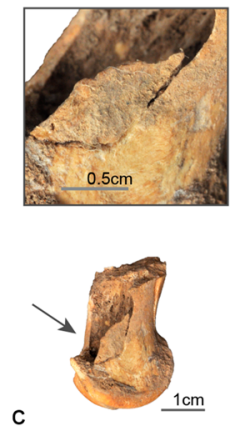

MAIN AGENTS
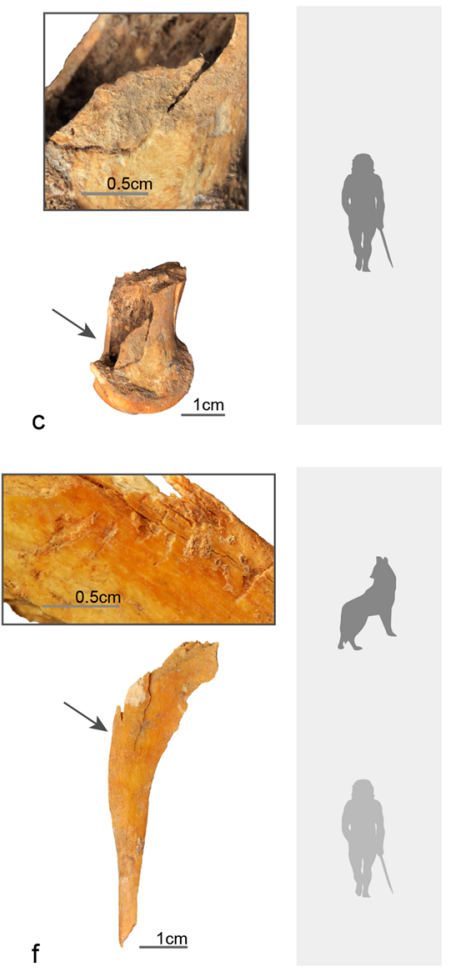

f
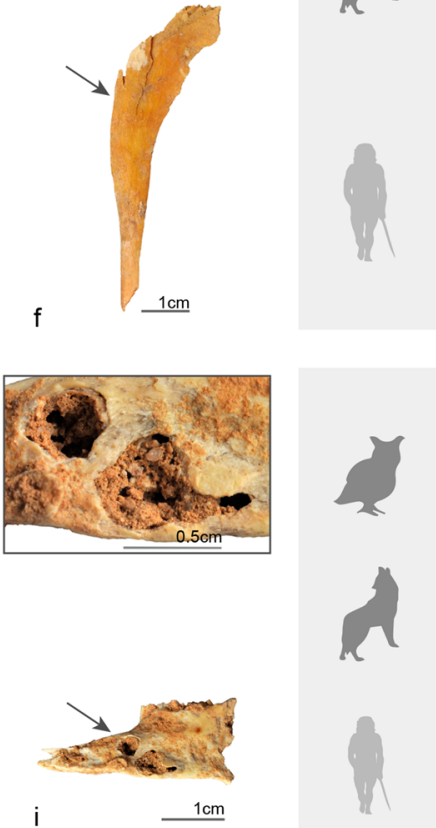

Fig. 10 Faunal remains from Cova de les Malladetes. Cervus: (a) thermo-altered first phalange with fresh fracture; (b) femur diaphysis with fresh fracture and cut marks; (c) second phalange with percussion. Caprinae: (d) humerus with fresh fracture and a percussion notch; (e) hyoid with cut marks; (f) tibia diaphysis with carnivore pits. Leporidae: (g) distal epiphysis of tibia with an anthropogenic notch; (h, i) tibia and mandible with nonanthropogenic punctures

(Columba livia/oenas). Considering that these three species are also documented at level XIVB, it cannot be ruled out that any of these remains correspond to level XIVA.

The red-legged partridge is a Mediterranean species that, in the Iberian Peninsula, occupies clear ecosystems in a wide altitudinal range: from the sea level to $1500 \mathrm{~m}$ asl but is scarcer in the Eurosiberian zone (Blanco Aguiar et al. 2002). The chough is 
included among the xeromontanas species, and pigeons are characteristic of the rupicolous area.

The identified species well respond to the characteristics of the Mediterranean climate, except for the alpine chough, which tends to be found in cold open spaces (Vilette 1983), strictly mountainous (Snow and Christopher 1997). In the Iberian Peninsula, the alpine chough occupies the mountainous areas of the north, with a preference for those areas with abundant rocks and more steep slopes (Sánchez Alonso 2002). The presence of the chough in level XIVA coincides with the appearance of Microtus arvalis, which is present exclusively within this level. These two species indicate that level XIVA corresponds to the coldest moment of the sequence.

In the Gravettian, levels X-XI, the remains of thrushes predominate (fieldfare and mistle thrush). The fieldfare (Turdus pilaris) is a Eurosiberian species that nests in boreal forests and hibernates between October and February in the Iberian Peninsula. The mistle thrush (Turdus viscivorus) extends to the Iberian Peninsula through wooded or partially wooded areas, with higher densities found in pine and montane oak forests. It is sedentary and partially migratory, with the northern population moving to the south in a number that varies depending on autumn and winter temperatures (Aparicio Santos 2002). At level X, the presence of the baillon's crake (Porzana pusilla) stands out, being a species of an aquatic environment, shallow waters and flooded lands with abundant vegetation (Cramp and Simmons 1994).

Modifications related to the accumulation of different agents have been identified (Fig. 11). Details of the remains with marks are presented in Suppl. Material 6, Table 4. Predator marks (D) correspond mostly to the corrosion of the articular ends and fractures of long bones because of passing through the digestive tract of nocturnal raptors. Anthropogenic marks (A) consist of incisions, scraping marks and fractures with peeling edges. There are no burnt bones.

In level XVI, only one anthropogenic mark has been identified on a chough bone. In level XV, there is only one remain with a nonanthropogenic mark. In level XIVB, despite the absence of another type of human modification on macromammals, anthropogenic marks are observed on a chough bone and on a red-legged partridge bone, perhaps coming from the supralevel.

In level XIVA, mixed accumulations can be observed: nocturnal raptors for doves, choughs, partridges and small passerine remains; anthropic in the case of doves, choughs and partridges remains. The species with the highest number of marks showing human consumption is the red-legged partridge (about $57 \%$ of the remains).

Among the remains in levels X-XI, only anthropogenic butchery marks have been identified: incisions and scraping marks on thrush bones. Based on the presence of lithic marks on a fieldfare humerus and the ethology of this species, human presence can be established in the winter at the site.

\section{Lithic Analysis}

The examined material corresponds to the remains recovered in sector Z-III (20162017) and the review of those from sector Z-II (1970), which was partially published (Fortea and Jordá 1976); both of these assemblages coincide stratigraphically up to level XIVA and are analysed together. However, because of the different screening 


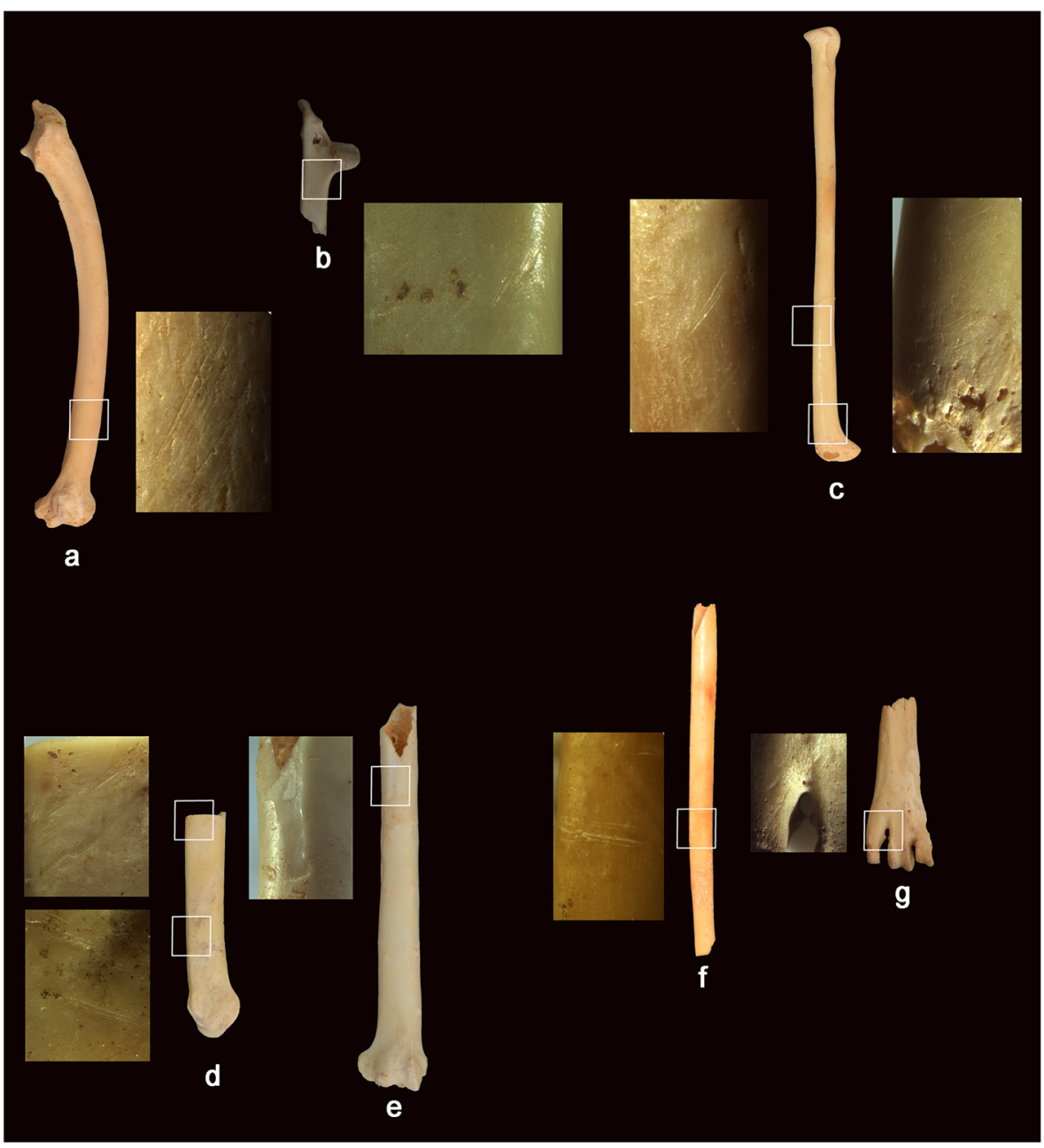

Fig. 11 Bird remains of Cova de les Malladetes. a Right ulna of Alectoris rufa (level XIVA) with incisions on the distal part of the diaphysis. b Right coracoid of Alectoris rufa (level XIVB) with incisions on the proximal part and a pit produced by a human bite. c Right radius of Columba livia/oenas (level XVIA) with short, oblique and parallel incisions on the distal part of the diaphysis. d Left ulna of a Pyrrhocorax pyrrhocorax (level XIVB) with two series of incisions in the medial part of the diaphysis. e Right ulna of a Pyrrhocorax pyrrhocorax (level XIVB) with a helicoidal fracture produced by peeling. f Right radius of a Pyrrhocorax pyrrhocorax (level XVI) with incisions on the distal part of the diaphysis. $\mathbf{g}$ Left tarsometatarsus of Pyrrhocorax pyrrhocorax (level XVIA) with two incisions on the distal epiphysis

system, there are quantitative contrasts in the NR and qualitative contrasts in the type of blanks, with a greater number of medium- and large-sized blanks in the 1970 campaign and smaller ones, especially chips and bladelets, in the recent excavation. From sector Z-II, we have included levels VII-XIV (now XIVA), except for level XIII because we have not managed to locate the materials in the Museu de Prehistòria de València. From sector Z-III, we have only included levels IX-XIVA, which are those that could be identified and excavated with a minimal surface area. 
Table 6 Gravettian and Aurignacian blanks by sector and level. Total counts by groups are presented: blanks, cores, CPRE (core preparation and rejuvenation elements) and debris

\begin{tabular}{|c|c|c|c|c|c|c|c|c|c|c|c|c|c|}
\hline & \multicolumn{5}{|c|}{ Aurignacian } & \multicolumn{8}{|c|}{ Gravettian } \\
\hline & \multicolumn{2}{|c|}{ XIVA } & \multirow{2}{*}{$\begin{array}{l}\text { XIII } \\
\text { Z-III }\end{array}$} & \multicolumn{2}{|l|}{ XII } & \multicolumn{2}{|l|}{ XI } & \multicolumn{2}{|l|}{$\mathrm{X}$} & \multicolumn{2}{|l|}{ IX } & \multirow{2}{*}{$\begin{array}{l}\text { VIII } \\
\text { Z-II }\end{array}$} & \multirow{2}{*}{$\begin{array}{l}\text { VII } \\
\text { Z-I }\end{array}$} \\
\hline & Z-II & Z-III & & Z-II & Z-III & Z-II & Z-III & Z-II & Z-III & Z-II & Z-III & & \\
\hline Flakes & 1 & 2 & 6 & 2 & 3 & 9 & 50 & 93 & 54 & 26 & 44 & 31 & 42 \\
\hline Laminar flakes & & & & 1 & 5 & 3 & 8 & 13 & 10 & 11 & 7 & 10 & 19 \\
\hline Blades & & & & & 1 & 1 & 13 & 22 & 6 & 9 & 4 & 8 & 5 \\
\hline Bladelets & & 6 & 5 & & 14 & 1 & 15 & 8 & 20 & 4 & 18 & 9 & 6 \\
\hline Splinters & & & & & & & & 2 & 2 & 2 & 3 & 3 & 1 \\
\hline Total of blanks & 1 & 8 & 11 & 3 & 23 & 14 & 86 & 138 & 92 & 52 & 76 & 61 & 73 \\
\hline Cores & 0 & 1 & 0 & 0 & 2 & 1 & 3 & 3 & 2 & 1 & 2 & 1 & 0 \\
\hline Crest blades & & & & & & & & 1 & & 2 & 2 & 2 & 2 \\
\hline Core tablets & & & & & & & & & 1 & & & & \\
\hline Core semitablets & & & & & & & 1 & & & 1 & & 1 & 1 \\
\hline Core flanks & 1 & & & & & 1 & 4 & 11 & 2 & 3 & 3 & 3 & 7 \\
\hline Core transversal $\mathrm{f}$. & & 1 & & & 1 & & & 1 & & 1 & & 1 & 5 \\
\hline Core lateral f. & & 1 & 1 & & & & 2 & 1 & & 1 & & & 3 \\
\hline Total of CPRE & 1 & 2 & 1 & 0 & 1 & 1 & 7 & 14 & 3 & 8 & 5 & 7 & 18 \\
\hline Chips & & 20 & 74 & & 55 & & 174 & 1 & 456 & 2 & 867 & & 1 \\
\hline Debris & & & 3 & & & & 9 & 1 & 6 & & 18 & 4 & 3 \\
\hline Thermal flakes & & & 1 & & & & 2 & 2 & 3 & & 15 & 1 & 1 \\
\hline Burin spall & & & & & & 1 & & 3 & 1 & & 2 & & 1 \\
\hline Total of debris & 0 & 20 & 78 & 0 & 55 & 1 & 185 & 7 & 466 & 2 & 902 & 5 & 6 \\
\hline Boulder & 0 & 4 & 1 & 0 & 0 & 0 & 2 & 0 & 0 & 0 & 0 & 0 & 0 \\
\hline Total by sectors & 2 & 35 & 91 & 3 & 81 & 17 & 283 & 162 & 563 & 63 & 985 & 74 & 97 \\
\hline Total & 37 & & 91 & 84 & & 300 & & 725 & & 1048 & & 74 & 97 \\
\hline
\end{tabular}

Although small in number, the materials provide a considerable amount of information for each archaeological period, as the technological and typological aspects are considered. In total, the NR found in levels VII-XIVA of sectors Z-II and Z-III totals 2456, of which 1650 are chips. The sequence, in turn, shows a contrast of density between the Gravettian levels, which has a larger amount of material, and the Aurignacian levels; the inflexion point between both periods lies in levels XI and XII (Table 6).

\section{Raw Materials}

The main raw material is flint (Suppl. Material 7, Table 5: Aurignacian and Gravettian raw materials evolution), with percentages that exceed $90 \%$ in all levels and $100 \%$ in the XIVA and XIII levels. Four types of flint were differentiated based on their characteristics. At least two allochthonous varieties were determined: the Serreta type 
and the Mariola type (Eixea et al. 2011, 2014, 2020; Menargues 2005; Molina Hernández 2015; Molina Hernández et al. 2010). The first is characterised by a variety of colourations, from dark black and green tones to lighter greys and oranges; its conchoidal fracture makes it of very good quality for knapping, and it was the most used variety. In the Aurignacian levels, this type represents almost $100 \%$ of the assemblage, while it tends to decrease throughout the Gravettian, with percentages in the initial levels close to $80 \%$, reaching its lowest value in level VII (52\%). The second one, which is of a medium quality for knapping, has a much lower relevance within the set. In the Aurignacian, it only appears in level XIII, whereas in the Gravettian, it is located in all levels. Contrary to what happens with the Serreta type, the Mariola type increases its presence in more recent chronologies, reaching 26\% in level VII. Both allochthonous varieties are present in nearby Upper Palaeolithic sites of Parpalló, Meravelles, Barranc Blanc and Cova de les Cendres (Eixea et al. 2020; Villaverde et al. 2019).

Along with these, two other types of flint have been characterised, both of which have marginal representations. The outcrops of these flint types are unknown, having not been located during field surveys carried out in the area by three coauthors of this work (A. E., A. M-A and M. A. B). We have named these flints type 1 (T1) and type 2 (T2). On the one hand, T1 has a good quality for knapping, even though it is less abundant, with values that do not exceed $5 \%$ in any of the levels, except for level XIII at 13\%; however, the NR is low. On the other hand, T2, with similar characteristics to the Serreta type, has a presence of $0.4 \%$ in level X and does not appear in any other part of the sequence.

The type of flint could not be determined in some pieces, mainly because of thermal alterations (cracks, changes in colouration and texture, etc.). Other elements of limestone and quartzite were recovered together with the flint. In general terms, the limestone is characterised as being of medium quality, with a grain of a mediumthick size and of light grey and dark colouring. It represents $8.9 \%$ and $9.7 \%$ of the remains in levels IX and X, respectively. Quartzite is insignificant; it is limited to levels IX $(1.1 \%)$ and VII $(1 \%)$. Both materials are of local origin and are identified in nodular formats along the ravines close to the cavity.

Concerning the catchment areas, the Mariola and Serreta types, which constitute most of the raw materials documented at these levels, are located between 15 and $30 \mathrm{~km}$ away from the site in secondary deposits of terraces near the coast; these could be easily transported from the original formations through the Serpis River and the adjacent ravines.

Considering the variety of raw materials used, a greater variety of types is observed (T1, T2, limestone and quartzite) in the levels where the density of lithics is higher. This points to a close relationship between the local provision and duration of the occupations or activities carried out at the site. In this sense, the limited - or even absent-nature of the provision is more evident in the Aurignacian levels, which is characterised as a very sporadic occupation.

\section{Basal Levels (XIVB-XVI)}

Levels XIVB to XVI could not be linked to a specific industrial phase because of the scarcity of remains - two chips in level XVI - even though levels XV and XVI offer 
evidence of anthropic activity: combustion structures and processing marks found on some bone remains. Level XIVB probably presents a human occupation hiatus. The limited excavated surface has undoubtedly affected this situation. It should also be noted that these levels were not excavated in the 1970 campaign. Considering the dates obtained, we will resume this discussion in a specific section ('Difficulties in the Cultural Characterisation of the Basal Levels'), where we also include an assessment of the materials from the 1940s excavations (Suppl. Material 8: Excavation of basal levels in 1940s campaigns).

\section{Aurignacian Assemblage}

The lithic assemblage from levels XII, XIII and XIVA (Table 6) is reduced: 212 remains were recovered, of which 149 are chips. It is worth mentioning that the scarcity of evidence is reinforced by the fact that it was not possible to include the materials from level XIII of sector Z-II and that the materials from Z-III come from a space of just over $1.5 \mathrm{~m}^{2}$. Therefore, the obtained data for these levels should be interpreted with caution because of the low NR.

The main purpose of lithic reduction in these three levels was to produce laminar blanks, which account for $80.8 \%$ of the blanks in level XII. This seems to correspond to sporadic and short-lasting occupations, in which some blanks and cores would have been brought to the site already prepared; here, there is also a smaller amount of flake debitage. Moreover, the number of cortical surfaces is low, and they are reduced to flakes and some laminar flakes, with no cortical surfaces accounting for more than $50 \%$. Pieces without a cortex are between $75 \%$ in level XIVA and $93 \%$ in level XII. Therefore, for this period, the chaîne opératoire is only partial because it does not include the beginning of the exploitation process.

Laminar blank production is linked to at least three methods of core reduction: prismatic, bâtonnet and carinated endscraper-core. This information can be complemented with that obtained from the core rejuvenation elements, which include a core flank from a unipolar prismatic core for a bladelet reduction and a lateral flank from a prismatic core. The resulting laminar component is characterised by small bladelets with an average length of $11.94 \mathrm{~mm}(\mathrm{SD}=2.83, n=11)$, and blades are almost absent. There are also some laminar flakes. An analysis of the dorsal surface and profile indicates a modality for producing typical blanks for Dufour bladelets by carinated endscrapers. The laminar assemblage is characterised by a scar distribution that shows unipolar longitudinal exploitation and concave or concave-twisted profiles with a fundamentally triangular cross-section; they were produced using soft hammers, the butts are mostly flat but with the presence of some punctiform and linear ones.

The retouched tools from the three levels comprise 19 pieces (Table 7), including microlaminar elements and, to a lesser extent, a burin and endscrapers, one of which is carinated. We did not locate any splintered pieces although de la Peña (2013b, p. 74) has mentioned one in level XIV from 1970, which we could not confirm. The importance of microlaminar elements lies in the information provided by the Roc-deCombe subtype Dufour bladelets, which are absent in the materials from the 1970 and 1946-1949 campaigns. Undoubtedly, the screening process has affected their recovery. They represent significant values concerning the assemblage from each level: eight pieces in level XII, one in level XIII and one in level XIVA, and some degree of 
Table 7 Gravettian and Aurignacian retouched tools by levels and percentage

\begin{tabular}{|c|c|c|c|c|c|c|c|c|}
\hline & \multicolumn{3}{|c|}{ Aurignacian } & \multicolumn{5}{|c|}{ Gravettian } \\
\hline & XIVA & XIII & XII & XI & $\mathrm{X}$ & IX & VIII & VII \\
\hline Endscrapers & 1 & & 1 & & 13 & 5 & 5 & 1 \\
\hline Combinations & & & & & 1 & 2 & & \\
\hline \multicolumn{9}{|l|}{ Perforators } \\
\hline Burins & 1 & & 1 & & 4 & 3 & 1 & 3 \\
\hline Backed tools & & & & 2 & 7 & 1 & 3 & \\
\hline Truncations & & & & 1 & 1 & & 2 & \\
\hline Pieces with retouch on one or two edges & & & 2 & 7 & 26 & 7 & 2 & 6 \\
\hline Notches and denticulates & 1 & & & 2 & 1 & & 1 & \\
\hline Splintered pieces & & & & 3 & 6 & 8 & 1 & 6 \\
\hline Scrapers & & & & & 1 & & & 1 \\
\hline Microlaminar tools & 3 & 1 & 8 & & 10 & 6 & 1 & \\
\hline Various & & & & 1 & 1 & 3 & & \\
\hline Total & 6 & 1 & 12 & 16 & 71 & 35 & 16 & 17 \\
\hline \multicolumn{9}{|l|}{ Backed points } \\
\hline Gravette & & & & 2 & 3 & 1 & & \\
\hline Gravettian shouldered point & & & & & 1 & & & \\
\hline Microgravette & & & & & 1 & & 2 & \\
\hline \multicolumn{9}{|l|}{ Microlaminar tools } \\
\hline Backed bladelets & & & & & 7 & 2 & & \\
\hline Pointed-backed bladelets & & & & & 1 & 3 & & \\
\hline Double-backed bladelets & & & & & 1 & & & \\
\hline Bladelets with marginal direct retouches & 1 & & & & 1 & 1 & 1 & \\
\hline Dufour-type bladelets & 1 & 1 & 8 & & & & & \\
\hline Bladelets with marginal inverse retouches & 1 & & & & & & & \\
\hline
\end{tabular}

standardisation is observed in them. They are all made from Serreta flint and have a curved profile. Some are twisted, and six pieces slant to the right. Here, $40 \%$ of the pieces are fractured, and most of them are characterised by bilateral retouch, inverse on the right edge and direct on the left edge. Moreover, two specimens only have retouches on one side, which are inverse and located on the right edge. Finally, a pseudo-Dufour bladelet has been recovered in level XIVA, with alternating retouch on the left edge (Table 8, Fig. 12a).

In short, data provided by the 2016-2017 campaigns have made it possible to confirm the identification of three Aurignacian levels and to show the significance of Dufour bladelets during this industrial phase at a regional scale.

\section{Gravettian Assemblage}

The number of lithic remains is larger in the Gravettian levels, especially in the upper levels, where the NR without chips is 268 in level X, 179 in level IX, 74 in level VIII 


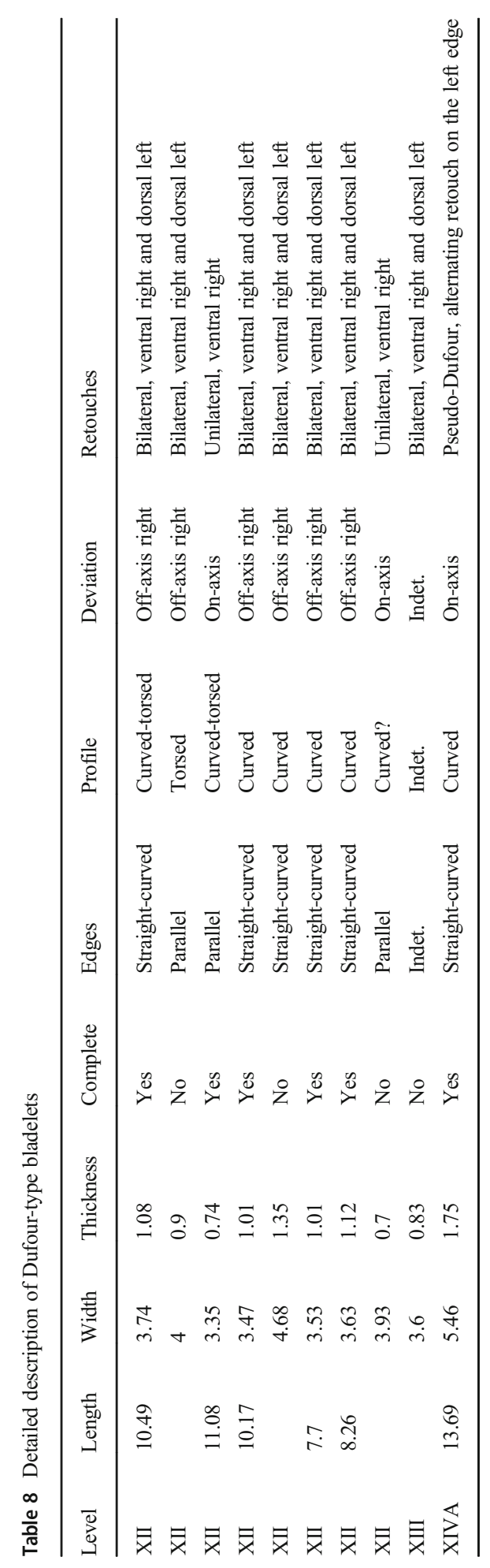


and 94 in level VII (the last two levels consisting only of materials recovered in the 1970 campaign), whereas the NR is 126 in level XI, showing a smaller amount of lithic remains (Table 6). If we limit the comparison to the materials recovered in Z-II to assess whether the number of pieces coincides with a stage of greater occupation, levels $\mathrm{X}-\mathrm{VII}$ are clearly associated with a larger density of materials than level XI, which is probably related to the Early Gravettian. This pattern of density has also been observed at a regional level in the sequence of Cova de les Cendres. Although previous research on the site suggested the possibility that level XI, which was excavated in 1970, could be related to the Aurignacian, the materials recovered in recent campaigns are consistent with its attribution to the Gravettian (two Gravette points, one truncation and numerous splintered pieces), which is also supported by the radiocarbon dates obtained in this level.

As in the Aurignacian levels, laminar blanks were the main objective of lithic production. The laminar index is around $40 \%$, though with significant diachronic changes. These indices are due to the preparation of the surfaces of the laminar cores

a)
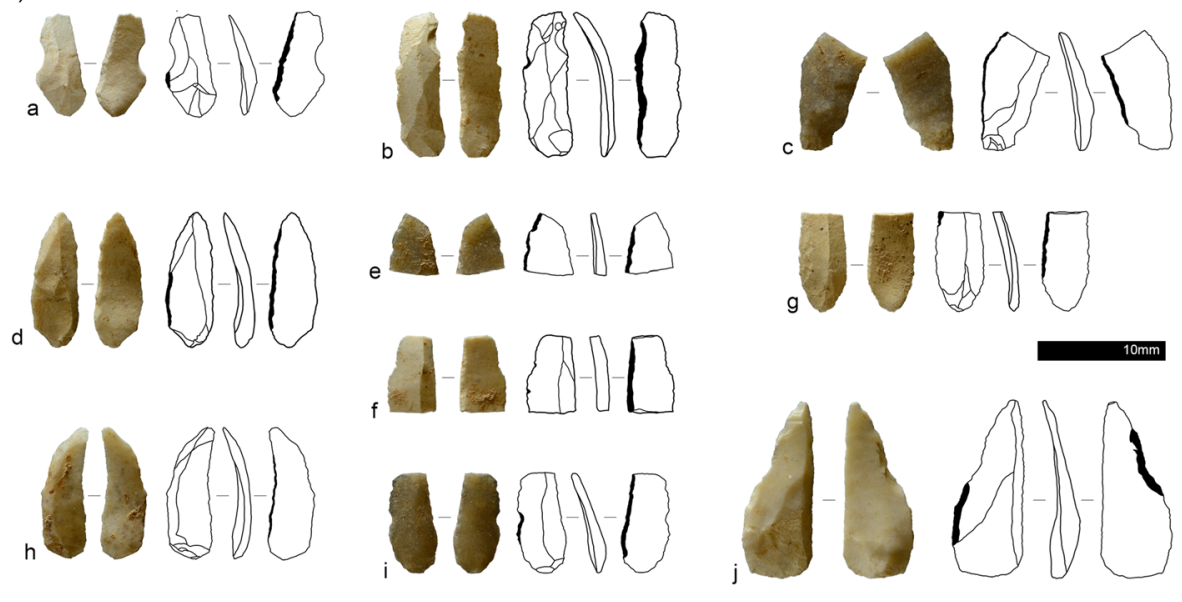

b)

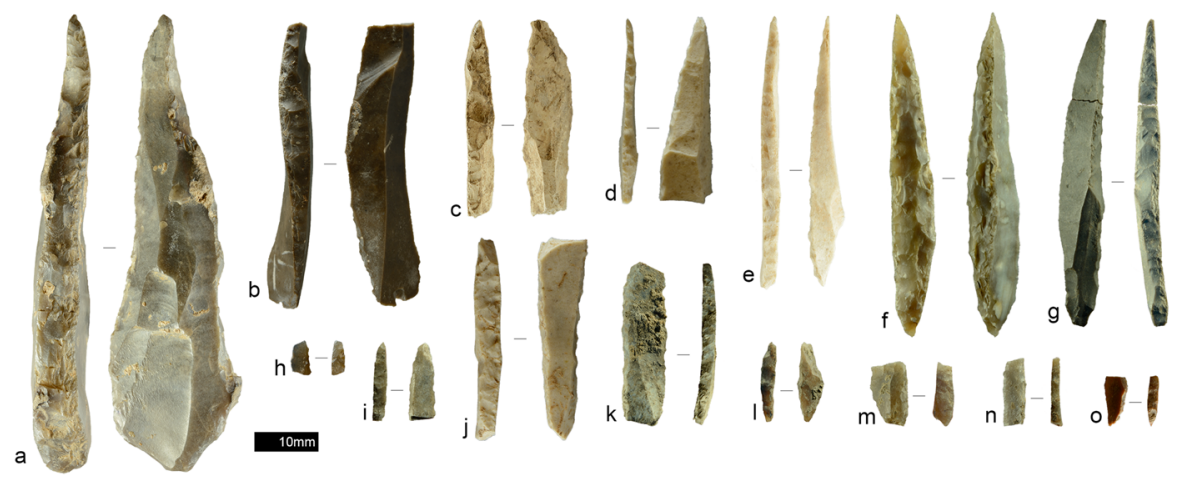

Fig. 12 Retouched material. a Aurignacian Dufour bladelets of Z-III: (a-d, f-i) level XII; (e) level XIII; (j) level XIVA. b Gravettian-backed projectiles of sectors Z-II and Z-III: (a-d) Gravette points; (e-g) microgravettes; (h, i) pointed-backed bladelets; (j) double-backed bladelet; ( $\mathrm{k}-\mathrm{o}$ ) backed bladelets 
removing flakes, which are present at the site, so the chaîne opératoire is complete. Cortical blanks are slightly more numerous at levels VII-X than at level XI. The first decortication phases are the least abundant, and an increase in the number of pieces is observed as the percentage of cortex on the surface decreases. When laminar blanks have a cortex, the surfaces with cortical areas account for less than $50 \%$. Pieces with less than $20 \%$ cortex are linked to maintenance rather than to initial phases. Subsequently, retouched cortical pieces have been found at all the levels, suggesting intensive use of the raw material, possibly because of somewhat longer occupations. Despite the presence of decortication phases, we cannot rule out the possibility that some of the material would have already been prepared before it arrived at the site.

Twelve cores or fragments were recovered, two of them being flake reduction cores (discoid and globular), and splinter production is documented for three cores. Laminarlike cores are well represented, with six specimens (three prismatic blade and laminar flake cores and another three prismatic bladelet cores) and one fragment that is difficult to classify. It is worth noting that at the levels of the same chronology in sector Z-IV - the study of which has not been included in the current work - a burin-core for bladelet production and two prismatic cores were also documented. Laminar-like cores are generally characterised by the fact that their initial reduction would have been guided by lateral meplats - with very few examples of partial or complete crest blades - and by the high degree of rejuvenation elements, especially core flanks and core lateral flanks that, together with tablets and partial rejuvenation flakes of the striking platform, allow maintenance of core surfaces.

As in the previous period, the small size of flint nodules would not have been conducive to blade production, so in most cases, laminar flakes and bladelets would have been produced. Longitudinal development of the complete laminar blanks provides a mean length of bladelets that does not exceed $25.9 \mathrm{~mm}(\mathrm{SD}=10.03 \mathrm{~mm}, n=$ 27), while for blades, it is $42.59 \mathrm{~mm}(\mathrm{SD}=11.37 \mathrm{~mm}, n=25)$. For levels VII, $\mathrm{X}$ and $\mathrm{XI}$, the cross-sections of the laminar blanks are predominantly triangular, while in levels VIII and IX, they are mostly trapezoidal, and many of them once again have lateral meplats. Most of the blanks have a concave profile, followed by flat and twisted profiles with unipolar and, to a lesser extent, bipolar parallel negatives. The most used type of hammer for laminar production is soft, especially mineral; hard hammering is only documented on some laminar flakes. Striking platform preparation traces are common on bladelets and somewhat more sporadic on larger pieces-essentially abrasion. Flat butts dominate, while dihedral, linear and punctiform ones are found in much lower percentages.

The retouched assemblage has provided various laminar and microlaminar backed tools that facilitate its cultural attribution (Table 7, Fig. 12b). In total, 155 retouched elements were recovered in Z-II and Z-III, the richest levels being IX and especially X. Throughout the sequence, the number of endscrapers is greater than burins, as is the case at many sites in the Mediterranean area of the Iberian Peninsula, such as Beneito (Iturbe et al. 1993) and Barranc Blanc (Fullola 1979; Miralles 1982). In turn, splintered pieces are one of the most represented types, coming with especially high values; many of these pieces come from the reuse of endscrapers or cores, making intensive use of the raw material, as is also the case in other assemblages of the same chronology, such as at Cendres (Villaverde et al. 2019). 
On average, backed pieces account for $15.5 \%$ of the retouched material, and this percentage is higher for levels VIII (12.5\%), IX (17.1\%) and X (19.7\%), with similar values to those found at level XVIA of Cendres. Backed projectile classification is similar to that proposed for the Gravettian assemblage at Cendres (Villaverde et al. 2019), where the proposed typometric classification attempts to go beyond the differentiation between blade and bladelet, Gravette point or microgravette. Backed bladelets are the most frequent type, since, in many cases, the distal parts are not preserved, due to the high degree of fragmentation. There is a predominance of large and small pieces, while intermediate sizes are somewhat more unusual, but we must be cautious when making this kind of assessment because of the low number of pieces. There are also fewer common elements: a Gravettian shouldered point and a double-backed bladelet were located in level X. Together with these backed elements, bladelets with direct fine retouches have an equal presence as the microgravettes in the microlaminar assemblage. Backed projectiles are characterised by a generally bipolar and quite invasive retouch, which creates rectilinear back margin morphology on Gravette points and microgravettes and a mostly direct and less-invasive retouch on microlaminar elements. Following the methodology extensively developed in specific works (Caspar and Bie 1996; Coppe et al. 2019; Coppe and Rots 2017; Rots and Plisson 2014), five projectiles show clear macrotraces of impact. Of these large- and medium-sized impact traces, the burin-like fracture is the most frequently repeated type (two Gravette points, one microgravette and one shouldered Gravettian point), and a bending fracture was also identified on a double-backed bladelet. No impact fractures were observed on pointed-backed bladelets.

Finally, we should also mention the documentation of five backed pieces (one Gravette point, two pointed-backed bladelets and two backed bladelets) in sector ZIV. All of this, together with the data from the 1940s campaigns (De la Peña 2013b), contributes to the industrial and chronostratigraphic characterisation of the Gravettian culture at Malladetes.

\section{Refitting}

Within the study of the lithic industry, an attempt was made to assess the integrity of the levels that compose this part of the sequence, and we tried to correlate the levels differentiated by Fortea in Z-II in the 1970 campaign $\left(6.25 \mathrm{~m}^{2}\right)$ with the levels recently excavated in Z-III (between 1 and $2 \mathrm{~m}^{2}$ ) through lithic refitting. Here, we present the results, stressing some of the detected problems.

First, it should be noted that this study is preliminary and that some features of the analysed assemblages make the search for refits difficult. On the one hand, $30.6 \%$ of the remains show patinas, many of them covering practically the entire surface; in addition, $31.7 \%$ of the elements are thermally altered, and a large number of remains have concretions that cover part of the surface. These three alterations, which in total affect around $60 \%$ of the studied assemblage, make it difficult to use the characteristics of the raw material (colour, texture, impurities, etc.) when identifying similar elements that can be refitted. On the other hand, it is necessary to take into account the bias derived from the collection of materials from the 1970 campaign because during the excavation, small-sized remains (less than $2-3 \mathrm{~cm}$ ) were hardly collected. 
A total of seven refits were found, integrating 14 pieces. There are five production sequences and two breaks, according to the typology of Cziesla (1990). Most have been found in Z-II and only one in Z-III, which may have been influenced by the the fact that a larger surface was excavated in Z-II and the presence of a higher number of large pieces, making more probable the finding of refits. All the connections are intralevel, and it was not possible to find any that connect the two studied areas. During the study, we gave priority to refitting limestone pieces because the identification of this raw material is easy and because of its significant proportion in the assemblage. In fact, two of the refits of the production sequences are on limestone. In any case and despite the approximate nature of the search, it is noteworthy that no refits were found between pieces from different levels; this may point to the relatively good preservation of the sedimentary units, with little mixing between levels, although we reiterate the provisional nature of the results.

On the other hand, it should be noted that we have scant spatial information regarding ZII. The surface was subdivided into four squares, but the material appears unified by pairs of squares, so the minimum spatial unit we have (because no remain was piece-plotted in 1970) is the archaeological level itself. In the case of Z-III, we have much more precise spatial references because a part of the pieces was piece-plotted, and the rest of the industry can be ascribed to units of $25 \times 50 \mathrm{~cm}$ in their maximum extension and about $5 \mathrm{~cm}$ thick (artificial layers in which the levels are subdivided). These conditions prevent a more detailed spatial analysis of refits (both horizontally and vertically), so we must limit our analysis to quantifying the connections by levels.

Two refits of the production sequences were identified in level VII of Z-II. In level VIII, we were able to find one of this same type and another of a break, and in levels IX and X, there is one refit of a production sequence in each. The only connection found in Z-III is within level XI, and it is a break type; in this case, with more precise spatial references, it connects two remains of adjacent subsquares and with a relatively short connection line. There are low percentages of success, with $1.6 \%$ of the remains refitted from the total studied assemblage. Analysing it by levels, there are proportions of around $1-2 \%$ in the units that have given results, save for level VIII, where it reaches 5.4\%; however, it should be noted that this is probably higher in the absence of any remains from Z-III for this unit.

Despite being provisional results, the current study provides information that points to a general panorama of little mixing between the different levels. It should also be noted that all refits were found at the Gravettian levels.

\section{Bone and Antler Industry and Ornament}

Available data from the 1970 excavation do not include for Z-II the location of bone and antler industry or ornaments. In 2016-2017, only one decorated single-bevelled bone point made on an herbivore metapodium was documented in level IX. Its decoration is composed of oblique lines (Fig. 13(a)). Level X has provided two fragments of Dentalium sp. and level XI a total of five decorative objects: three perforated Theodoxus fluviatilis and two fragments of Dentalium sp. (Fig. 13(d-j)).

Concerning the data from the 1940s excavations, two antler points come from the basal levels, and by their type and position in the sequence, they must be related to the Aurignacian. These are two massive base points that come from sector D spit 22 (1947) (Fig. 13(b)) and sector E spit 15 (1948) (Fig. 13(c)). Both pieces have been studied by Tejero (2013) and Doyon (2019), the latter focusing on the Aurignacian osseous 


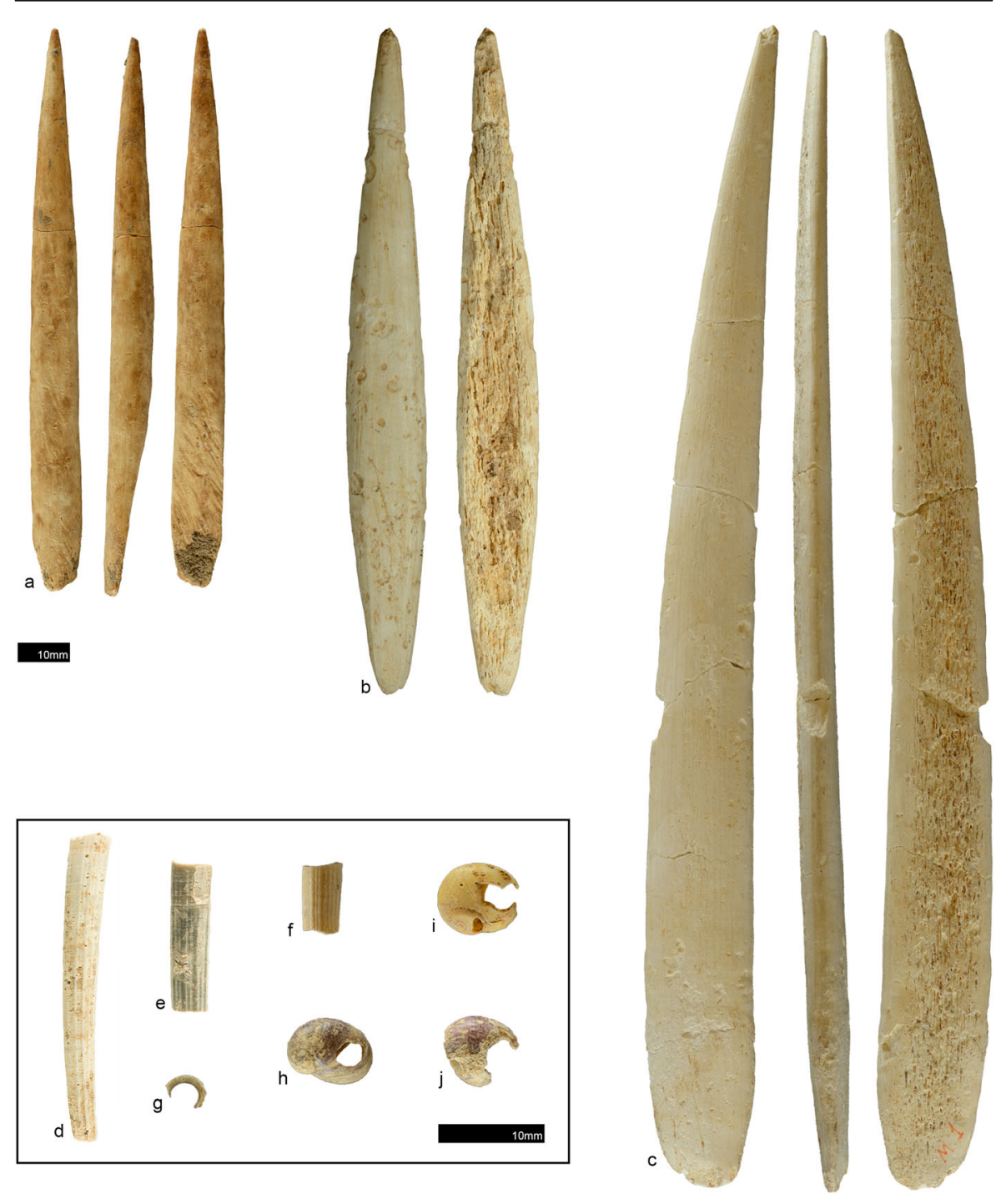

Fig. 13 Osseous industry and ornaments. (a) Single-bevelled point. (b, c) Aurignacian massive base tips. (dg) Dentalium and (h-j) Theodoxus fluviatilis

projectile points in Southern Europe. Both authors stressed the large size of the piece from 1948, which stands out both at the Iberian and European level and in which its affiliation with the Evolved Aurignacian does not present a problem. Specifically, Doyon (2020) compared the piece from sector E spit 15 with a similar sized piece of Velika Pečina in the Hrvatsko Zagorje region (Croatia).

\section{Radiocarbon Dating}

A series of 32 new dates from sector Z-III were obtained. All these new radiocarbon dates from Malladetes were obtained from taxonomically identified wood charcoal 


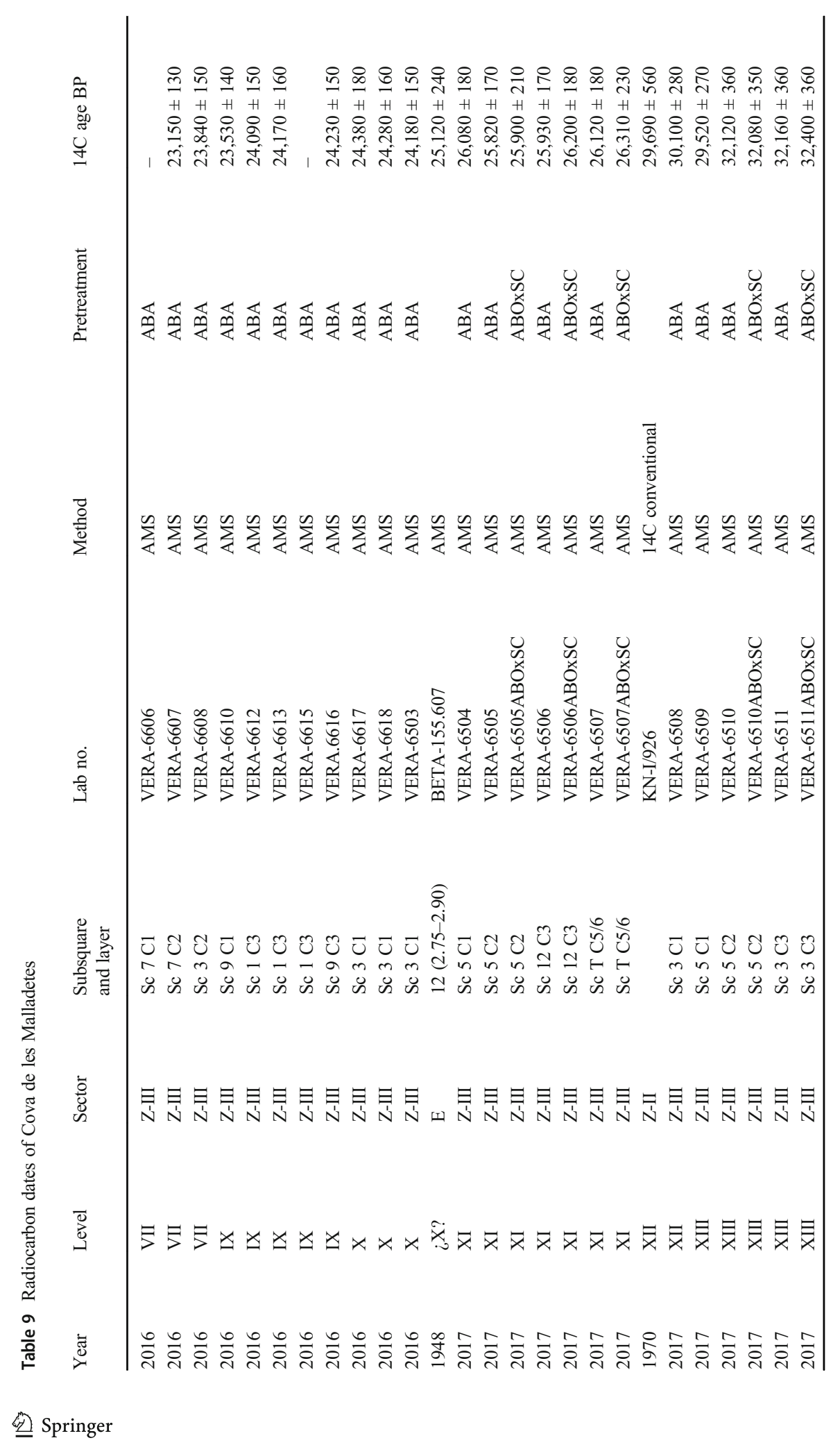




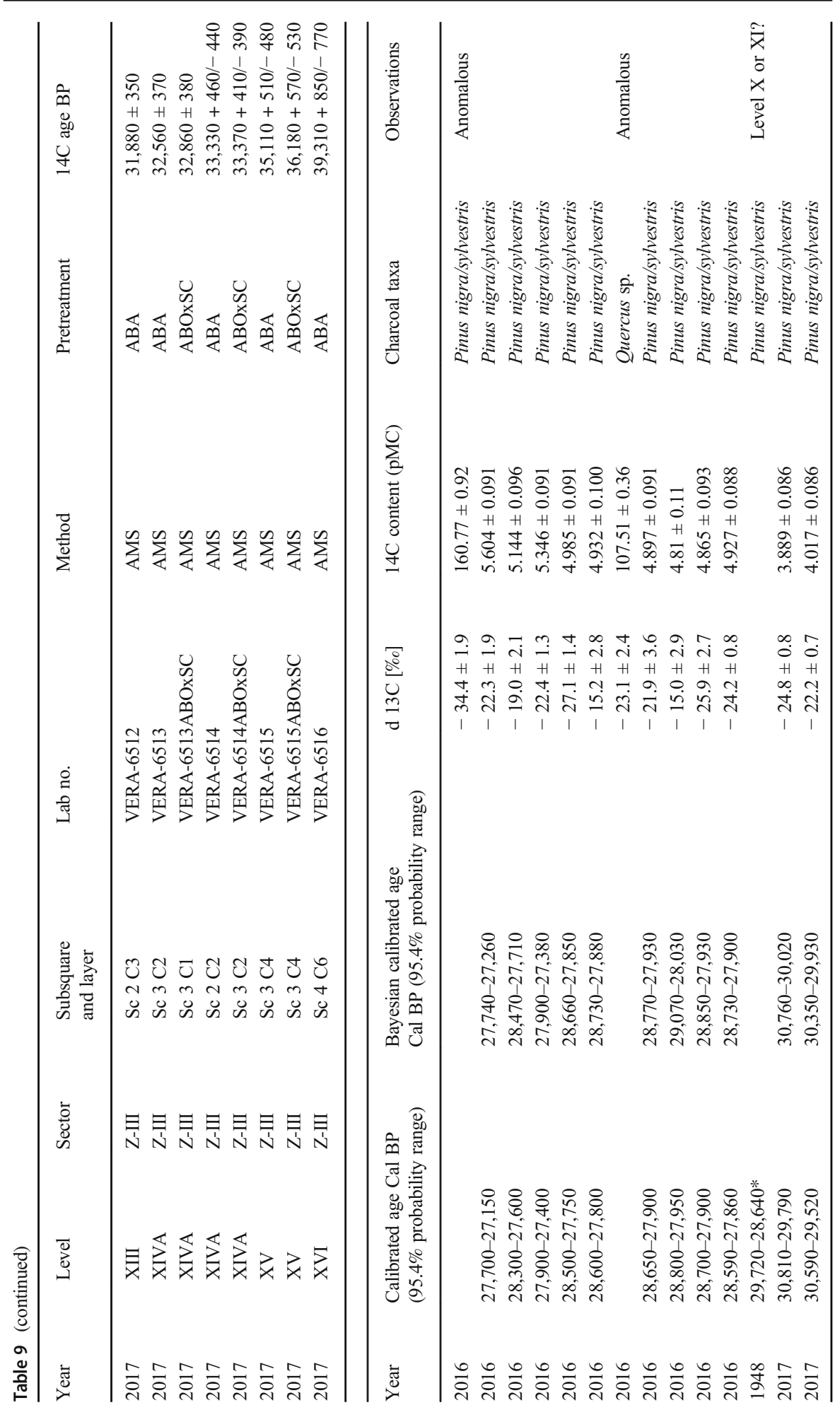




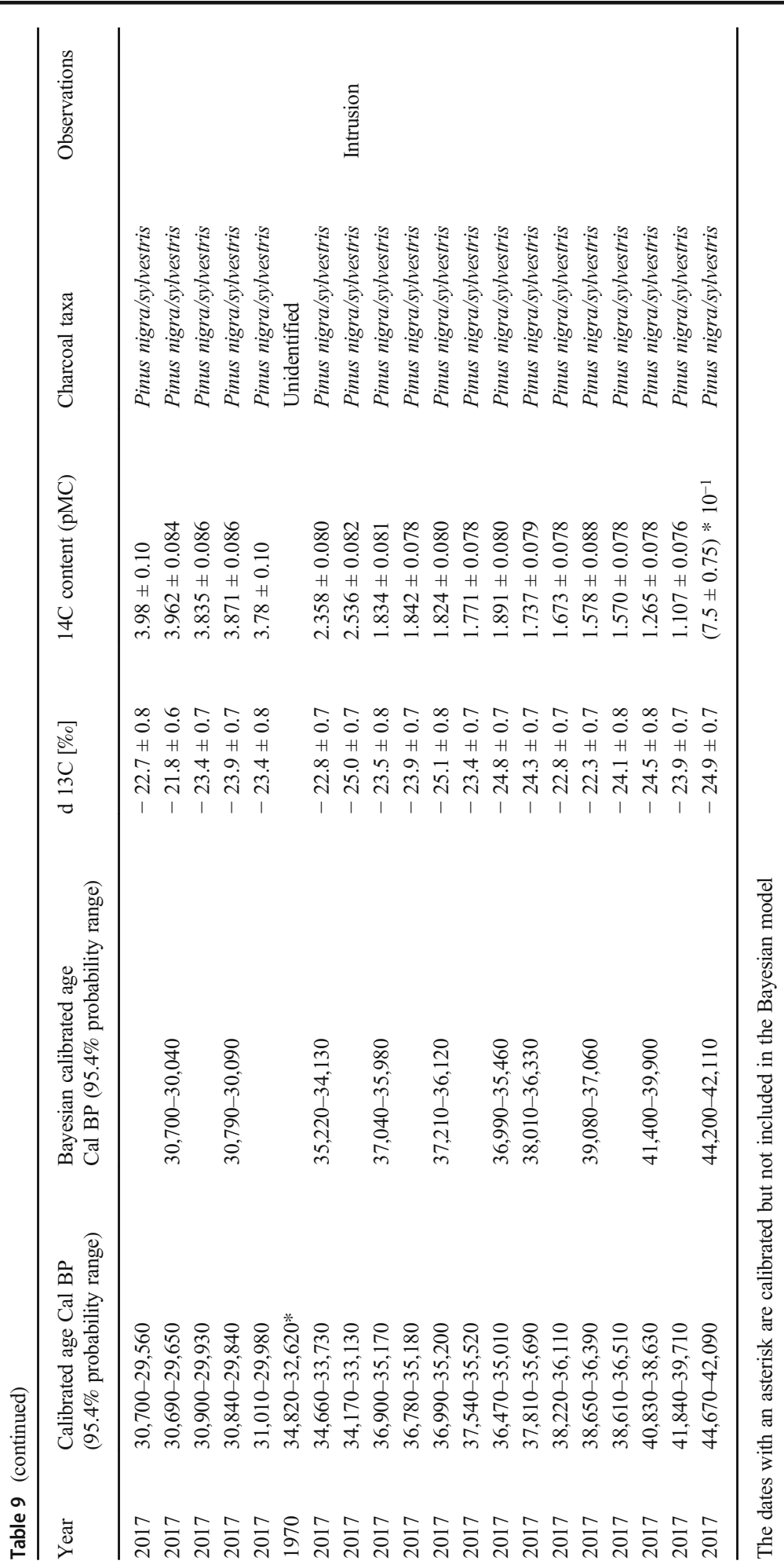

\section{글 Springer}


samples and submitted to the Vienna Environmental Research Accelerator (VERA). In some cases, one subsample was dated after pretreatment with a modified ABOxSc method - similar to the method described in Brock et al. (2010) — and another one after applying the ABA method (see, e.g. Wild et al. 2008).

In this assemblage of dates, two provided modern results: VERA-6606 is certainly an intrusion that came from the mixed surficial level (in direct contact with level VII) (Fig. 3a), and VERA-6615 is surely a charcoal fragment detached from a surficial level of the profile (Table 9). Furthermore, date VERA-6509 of level XIII results from burrowing or an intrusion.

Previously, only two dates were available. In the Fortea and Jordá's excavations, one date from level XII (KN-I/926) was obtained for the Aurignacian. More recently, a wood charcoal fragment of Pinus nigra/sylvestris preserved in spit 12 of sector E (1948 excavation) (BETA-155.607) and associated with a child occipital deposited in a small niche in that sector (Arsuaga et al. 2002) corresponded to the Gravettian (Table 9).

Derived from the characteristics of the associated stone tools, it is possible to group dates by industrial phases: 17 dates for the Gravettian-16 from Z-III and one from sector E (1948) (BETA-155.607) — and 12 dates for the Aurignacian - 11 from Z-III and one from Z-II (KN-I/926). The three dates from Z-III that present problems were not considered. Basal levels XV and XVI, which show evidence of anthropic activity but without diagnostic lithic industry, were considered as two culturally undetermined phases. Because of the consistency of the obtained series of dates, we could build the Bayesian age model for Malladetes using OxCal4.3.2 software (Bronk Ramsey 2009, 2017) and the calibration curve IntCal13 (Reimer et al. 2013) with 29 samples from the sector Z-III. A detailed description model and code model are provided in the Suppl. Material 9: Bayesian model of radiocarbon dates.

Therefore, the Bayesian model places the Aurignacian (XII-XIVA) in Malladetes between 39,100 and 34,100 cal BP, and the Gravettian between 30,800 and 27,300 cal BP (Fig. 14). Regarding the basal levels (XV and XVI), level XV is placed between 41,400 and 39,900 cal BP, here considering the result obtained by treating the sample with the ABOxSC method (VERA-6515ABOxSC). Level XVI is between 44,200 and 42,100 cal BP. Considering the Bayesian model results, the boundary between the basal levels (XV-XVI), which are culturally undetermined, and the Aurignacian is situated between 40,400 and 37,000 cal BP; the boundary between the Aurignacian and Gravettian is situated between 32,300 and 30,200 cal BP.

\section{Discussion}

\section{Palaeoenvironmental and Palaeoclimatic Interpretation}

In all levels of Malladetes, almost all the anthracological assemblage belongs to cryophilous pines (Pinus nigra and/or P. sylvestris). Here, diverse causes could explain the homogeneity of the assemblage along the sequence:

- The high frequency of pine wood charcoal remains could be due to the development of cryophilous pine formations in the firewood catchment area of Malladetes throughout the sequence. The abundance of a species in the surroundings of a site would facilitate its systematic gathering. 


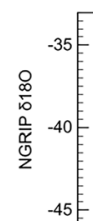

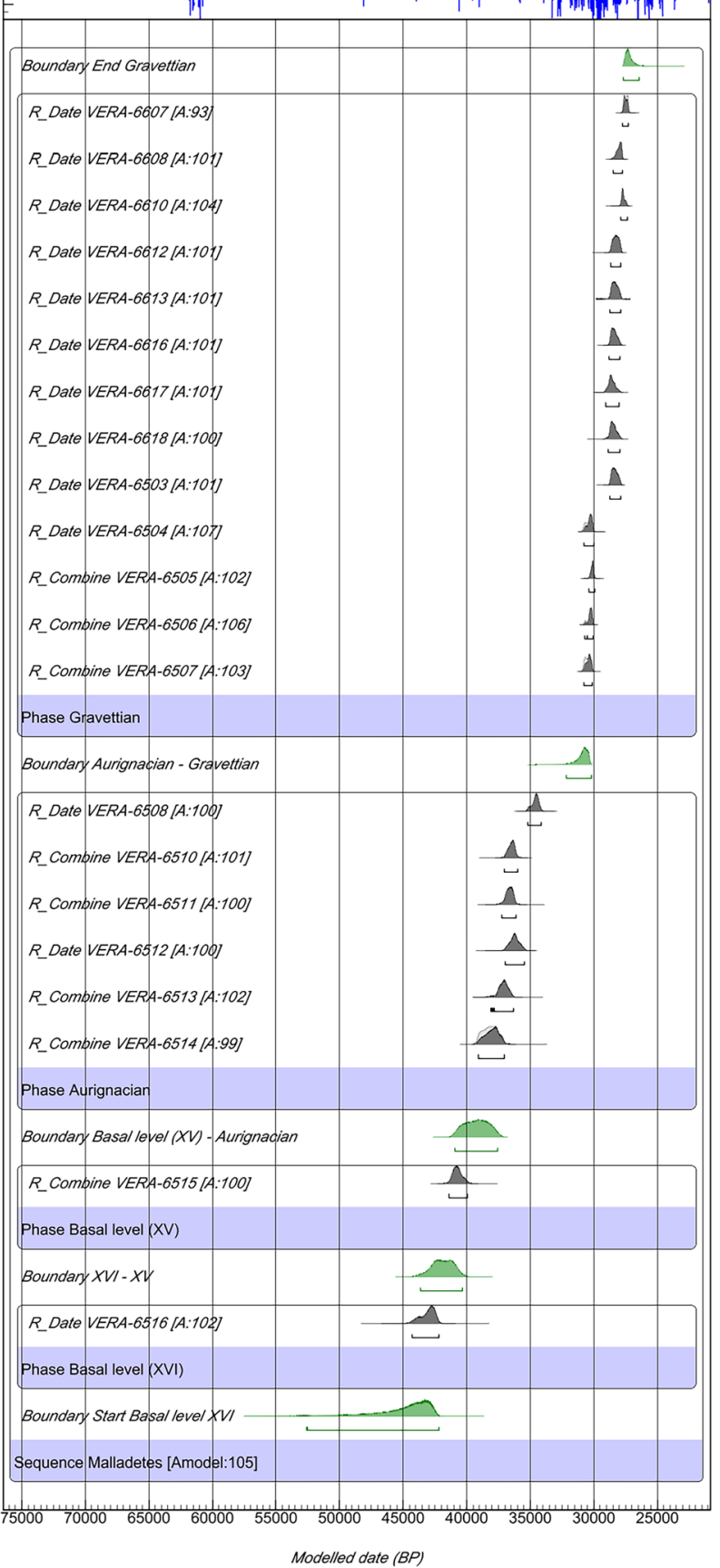


Fig. 14 Chronological Bayesian model of radiocarbon dates from sector Z-III. $A_{\text {model }}=105$ dates introduced as R_dates and R_Combine (for a double date from same sample). Boundaries between phases marked in green

- A cultural selection of pine firewood could not be rejected; however, in most Palaeolithic sites, taxa diversity is higher than in Malladetes (Badal and Martínez Varea 2018; Martínez Varea and Badal 2018). We do not know the selection criteria of fuel of these human groups, but even when there is a preference for a plant, other species from the same biotope are always represented too, even though their use was more sporadic (Asouti et al. 2018; Carrión et al. 2018).

- Most likely, prehistoric people also burned small-calibre plants, such as Erica sp., Fabaceae and Cistaceae, but precisely because of their small size and perhaps because they were used to light fire, they can more easily turn to ash.

- The absence of other species, such as evergreen and deciduous Quercus, among the firewood waste could be due to their absence in the area, which could be explained by the prevailing cold climatic conditions.

- Finally, as previously indicated, angiosperm charcoals are very altered, and their presence in the assemblage is probably biased because of their lower resistance to postdepositional processes, such as weathering, fragmentation and so forth, as some researchers have pointed out (Chrzazvez et al. 2014; Vidal Matutano 2016).

Regarding the nonwoody remains (seeds and leaves), their scarce presence makes them difficult to interpret, but we can point out three possible routes of entry: natural deposition, food gathering and firewood collection by humans. The identified Fabaceae seeds belong to nonwoody taxa, so their presence could be explained by a human gathering of food, as documented at other Palaeolithic Mediterranean sites (Aura Torsosa et al. 2005; Baines et al. 2015; Hansen 1980; Savard 2000). The presence of a cf. Sambucus sp. seed could be explained in the same way because their fruits are edible. Nevertheless, we cannot dismiss the natural entry of some remains because of the position of the sampled area in a more external part of the site and because of the wideness of the cave mouth.

Combining flora results of the anthracological and carpological analysis of Malladetes, we obtained a reconstruction of the palaeolandscape and plant use. Throughout the sequence, pine formations dominated the landscape, combined at some points with junipers, heathers, rockroses, woody and herbaceous legumes and other herbaceous plants, along with other indeterminate dicotyledons.

From a climatic point of view, the identified taxa among the carpological assemblage have a wide tolerance when it comes to their temperature and humidity; hence, they are not good biomarkers. However, the presence of Pinus nigra/sylvestris wood charcoal fragments is a high-value bioclimatic marker because it indicates mean annual temperatures around $8-10{ }^{\circ} \mathrm{C}$ and precipitations of a dry to subhumid type along the Upper Palaeolithic in the area of Malladetes. This would be $7{ }^{\circ} \mathrm{C}$ or $10^{\circ} \mathrm{C}$ less than current temperatures, where the mean annual temperature is around $17-18{ }^{\circ} \mathrm{C}$.

These cold climatic conditions could explain the predominance and stability of the cryophilous pine formations throughout the entire sequence. The charcoal and seed analysis results are homogeneous in all levels: even in the levels placed chronologically during interstadials, neither changes in the flora composition nor in the presence of 
thermophilous species could be documented. In the ice core, interstadials are well identified, but most likely, they would be too short to have a real impact on the terrestrial ecosystems. This could explain the similarity of the composition of the flora in all levels at Cova de les Malladetes. To this, we must add the altitude of the site (551 $\mathrm{m}$ asl), which should be a limiting factor to the growth of warmer plants, which were detected in the deposits at the lower altitude and closer to the Palaeolithic coastline.

Palynological and sedimentological analyses conducted in the 1970 s provided information on the landscape and the palaeoclimatic conditions (Dupré 1980; Fumanal 1986). Both analyses agreed on the formation of the Aurignacian and Gravettian levels during Würm III, which occurred during cold and arid conditions, though some climatic pulsations regarding humidity and temperatures were detected. In the palynological sequence, the AP/NAP curve is dominated by herbs, and arboreal pollen is almost composed solely of Pinus sp. pollen, which in some levels reaches $50 \%$ of the assemblage. Termophilous Mediterranean taxa appear occasionally, and Quercus sp. can only be identified in levels IX and X in low percentages. Eurosiberian taxa are absent. Based on pollen data, the landscape was reconstructed as a pine formation, which was more or less open depending on the climatic oscillations and was more conditioned by humidity than by temperature fluctuations. In the wettest periods, there would be more pines, whereas in the driest stages, there would be more herbaceous plants. In any case, the whole sequence denotes a cold environment. This conclusion was also reached by the sedimentological analysis carried out by Fumanal (1986).

Results of the analysis of macrobotanical remains concur with this description but with some differences. Among the anthracological remains, Pinus nigra/sylvestris is the dominant taxon, which confirms the supra-Mediterranean-type bioclimatic conditions throughout the entire sequence. The carpological remains support the diversity of herbaceous plants, as pointed out by the pollen analysis, although among the families identified in the pollen assemblage, just the macroremains of the Asteraceae, Ericaceae and Lamiaceae families have been recovered together with a stem of a monocot. On the contrary, no Poaceae or Chenopodiaceae remains have been documented, even though their presence stands out in the palynological diagram.

Based on the ecological requirements of micromammals, we can confirm the development of fresh and humid climatic conditions in the Malladetes area. These conditions are harsher in level XIVA, where Microtus arvalis has been identified, which is characteristic of the bioclimatic oro- and supra-Mediterranean areas (Table 4) and where the alpine chough (Pyrrhocorax graculus) is also present, the only avifauna species found in cold conditions. On the other hand, the presence of Talpa occidentalis in Mediterranean environments is usually linked to exceptionally humid periods that allow this species to dig burrows, even during the summer months, and it is usually found in mountainous areas. In Malladetes, it is only present in levels XIVB and XV.

This degree of humidity is consistent with the presence of Crocidura suaveolens in levels XIVA, XIVB, XV and XVI (Table 4) and with $M$. cabrerae in all levels. The $M$. cabrerae populations occupy the bioclimatic meso- and supra-Mediterranean zones; therefore, this reflects the development of cooler and more humid climatic conditions than those currently found.

Consequently, regarding the landscape, forest formations would be predominant. Meadows with well-structured soils would be the ecological niche of T. occidentalis, 
and areas with a high-water requirement and evergreen vegetation needed by M. cabrerae would abound.

From a regional perspective, $50 \mathrm{~km}$ away from Malladetes, Cova de les Cendres (Teulada-Moraira, Alicante) has provided interesting archaeobotanical results that can be compared with those of Malladetes for the Aurignacian and the Gravettian levels. The main common point is the predominance of the cold ecology taxa (Pinus nigral sylvestris), but the largest difference is the taxonomical diversity. The archaeobotanical assemblage of Cendres is extremely rich compared with Malladetes (Fig. 15). This means that in the surroundings of Cendres, more diversity in the ecosystems had developed (Villaverde et al. 2019). The location of the cave, 10-15 km from the coast in the Palaeolithic, and the presence of dunes, ponds and rivers favour the development of rich biotopes, a rich source of resources for human groups (Martínez Varea 2019). On the contrary, around Malladetes, the available ecosystems would have been less diverse, probably because of its high altitude. Moreover, the differences in the occupation system could explain the less-rich qualities of the Malladetes assemblage: during short occupations, firewood and food needs would be low, leaving less waste, that is, archaeological remains. The difference in the diversity regarding the carpological assemblages could be partially explained by taphonomic processes because the stable environment in Cendres would contribute to the preservation of plant remains, even the most fragile ones, whereas in the more open cave of Malladetes, the weathering processes would affect the remains more.

Regarding the taxonomical composition, in Cendres and during the Aurignacian, the landscape was dominated by Juniperus sp. and Pinus nigra/sylvestris, whereas during the Gravettian, Pinus nigra/sylvestris and Fabaceae became the most important taxa, with Juniperus sp. reaching its lowest levels. Quercus sp. is present in all the sequences but in low proportions. In Malladetes, the dominance of Pinus nigra/sylvestris and the practical absence of Juniperus sp., which only can be documented in the carpological assemblage, point to a higher rainfall regime than in Cendres. This difference has an orographic explanation: Malladetes is in the Mondúver Massif, which is characterised

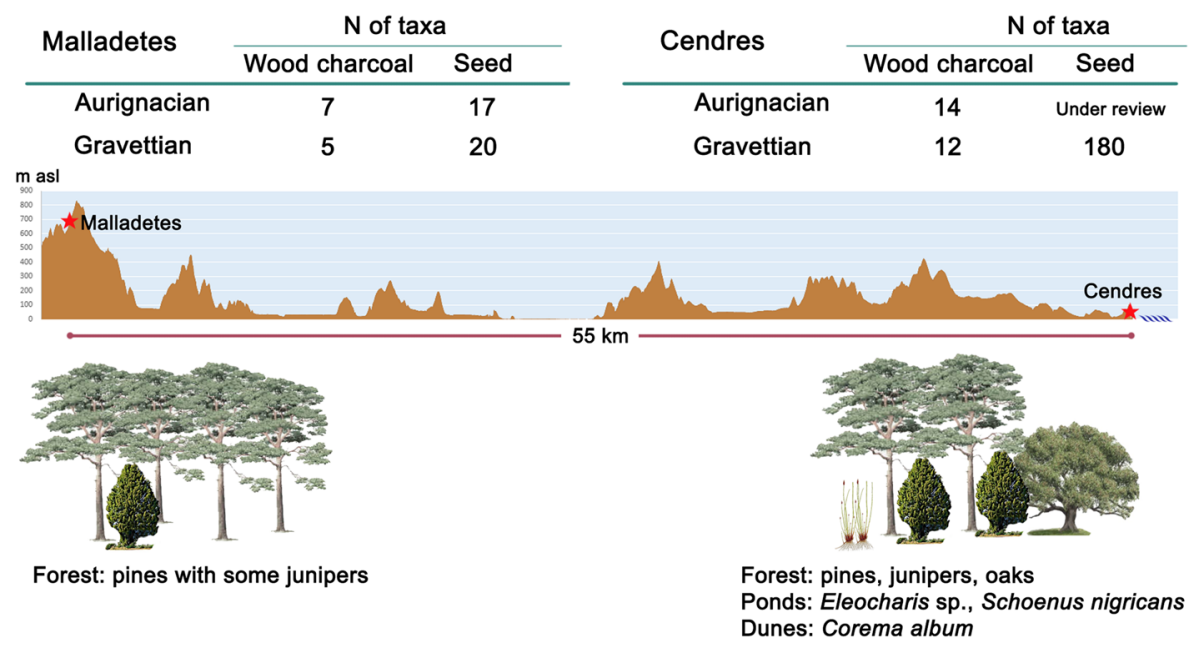

Fig. 15 Archaeobotanical data and topographic profile. Comparison of the landscape surroundings of Cova de les Malladetes and Cova de les Cendres. Current metres above sea level (m asl) 
by a subhumid to near humid ombroclima, with an annual rainfall of around $900 \mathrm{~mm}$, far surpassing the mean rainfall of the region. Regarding the temperatures, judging by the presence of Pinus nigra/sylvestris, the situation would be similar to that of Cendres.

\section{Human Occupation Patterns in Malladetes and Their Regional Context}

\section{Hunting Activities}

The 1970 excavation at Malladetes made it possible to update and systematise the regional Upper Palaeolithic sequence (Fortea and Jordá 1976), which until that time was limited to the largely industrial data provided by the excavations carried out between 1929 and 1931 at Parpalló (Pericot 1942). Only the study of the fauna from Parpalló and Malladetes carried out by Davidson (1981) provided information on the economy of the hunter-gatherer groups during the Upper Palaeolithic at a regional scale. However, the information concerning the EUP was very limited.

Considering our archaeozoological results and in relation to the occupation patterns at the site during the EUP, regardless of the origin of the samples, the taxonomic spectrum of the sequence reflects the recurrent use of nearby areas. For example, the presence of caprine remains connects with an ecotone of a medium altitude and steep reliefs, and the red deer would be in areas with a larger forest density. The presence of forest species such as wild boar and roe deer in the Gravettian, although appearing in low values, could be related to a climatic improvement compared with the basal levels of the sequence. There is hardly any evidence of species linked with open areas, such as equids - only in the Gravettian and level XVI — and large bovids - only in the Gravettian. Moreover, the absence of carnivores is truly remarkable, with only one element in level XV. In the study of the faunal assemblage recovered in the 1940s, however, some carnivore species such as leopard (Sanchis et al. 2015), dhole (Sanchis and Villaverde in press) or lynx have been identified in the EUP and basal levels.

Regarding the basal levels, in level XIVB, no anthropic evidence has been identified on faunal remains, and the leporid remains seem to be related to the feeding of raptors. The fauna from level XV is preferentially connected to carnivore accumulations because lithic marks have been identified only on a lynx bone. Bone accumulations in level XVI appear to be of a mixed origin, of carnivores on caprine, of raptors on leporids and of humans on medium- and large-sized prey, possibly red deer. At the latter level, the secondary access of carnivores on remains previously processed by humans has been determined.

As will be explained later, the hypothetical correlation of the basal levels (XV-XVI) with the Middle Palaeolithic brings up some issues in terms of making comparisons, not only because of the scarcity of recovered faunal remains, but also because the samples assigned to this chronology are few at a regional scale. However, we can consider the MIS 3 fauna of Cova Beneito (Iturbe et al. 1993; Martínez Valle 1996) and El Salt (Pérez Luis 2019; Pérez Luis et al. 2015, 2017). In Cova Beneito (D1-D4), the caprine, red deer and leporid accumulations are mixed although carnivores are the main accumulation agents. Of interest is the presence of several species of carnivores (hyena, wolf and lynx) in Cova Beneito, while in Malladetes, only one lynx bone was documented. This being so, and as mentioned before, the analysis of the fauna recovered in the 1940s (basal levels of sectors D and E) has allowed to determine 
some carnivore bones and also ungulate remains that have been accumulated and consumed by carnivores. These bone assemblages come from the most cavernous and protected area of the site, which could have been used as a den. In El Salt, although some carnivore remains have been documented at level Xa (wolf, dhole, lynx and leopard), their presence is rather marginal, both in number and in ungulate accumulation, and mainly have an anthropic origin. In this site, only the leporids are related to raptors' activities (Pérez Luis 2019; Pérez Luis et al. 2015, 2017).

The comparison between the Malladetes assemblages belonging to the EUP shows an increase in the intensity of ungulate accumulation of human origin during the Gravettian. This can be seen in the number of bones with anthropogenic modifications, the increase of burnt bones (3.7\% in the Aurignacian and $25.5 \%$ in the Gravettian) and the greater intensity of the human occupations during the Gravettian. Nevertheless, these data are preliminary, and it is necessary to conduct a suitable analysis of the complete assemblage, including the bone remains from the 1940s and 1970 excavations, to evaluate their economic implications.

The taxonomic spectrum at the Aurignacian and Gravettian levels of Malladetes (ZIII, 2016-2017) coincides with what Davidson suggested for the fauna recovered during the 1970 excavation (Z-II) (Davidson 1989). The assemblage studied by Davidson, however, is smaller, so no comparisons can be made regarding the anatomical representation, the age of death or the origin of the samples. On the other hand, recently, the revision of the leporid remains of the 1970 excavation has been carried out, as well as the archaeozoological and taphonomic study of the leporids recovered during the 1940s excavations. Here, the Aurignacian assemblage corresponds mainly to raptor accumulations, as indicated by the level of fragmentation and the modifications caused by beak impacts and digestion (Sanchis et al. 2016).

In the regional context of the EUP, there are a few deposits that provide faunal information: Cova Foradada (Xàbia) (Martínez Valle 1997; Pantoja et al. 2011; Verdún-Castelló and Casabó 2020), Cova Beneito (Iturbe et al. 1993; Martínez Valle 1996), Cova de les Cendres (Pérez-Ripoll 2004; Villaverde et al. 2019), Cova del Comte (Casabó et al. 2017) and Cova de la Barriada (Fernández-López de Pablo et al. 2014). For most deposits, there are only preliminary results and few taphonomic data, so it is difficult to assess the origin of the faunal accumulations and characterise the processing and consuming activities conducted by the human groups.

Concerning the Aurignacian, for now, the comparative sample is reduced to Foradada and Beneito because the levels at Cendres are pending publication. In Foradada, the caprine accumulation predominates, followed by red deer, with low values of other ungulates such as auroch, horse, wild ass and wild boar, along with the presence of some carnivore remains (leopard, lynx and wildcat). The leporid accumulations are very prominent and can be attributed to anthropic activities (Martínez Valle 1997). Ungulates are mostly of an anthropic origin, while the role of carnivores in their formation is lower (Pantoja et al. 2011). In Beneito, the leporids of the Aurignacian levels represent $85-90 \%$ of the remains, followed by caprine and red deer, along with the presence of some carnivores. Anthropogenic and carnivore marks were documented on ungulate bones, showing mixed contributions. In the case of leporids, both consumption modifications of raptors and humans were identified (Martínez Valle 1996), whereas in Malladetes, they have mainly a nonanthropic origin. Overall, the information from Malladetes seems to confirm the presence of a mixed 
accumulation in the case of the caprine and the anthropic origin of the accumulation of cervids.

Regarding the Gravettian, the taxonomic spectrum of the different sites includes ungulates of several sizes although with a predominance of red deer and caprine together with the presence of some carnivores and small prey, such as leporids and birds. In all of them, leporids are the most important prey when judging by NISP. Both the ungulates and leporids of these levels show a predominance of anthropic accumulation although data on leporids are inconclusive because of a lack of taphonomic studies or conservation problems in sites such as Foradada, Beneito, Comte or Barriada. In Cova de les Cendres, there is more detailed information (level XVIA) and the amount of identified remains is considerably higher than in Malladetes. Moreover, and unlike what is observed at Malladetes, there is a greater diversity of species, including various carnivores such as Vulpes, Lynx, Felis, Meles or Monachus (Villaverde et al. 2019). Likewise, leporids are the main taxa in both cases although they represent $88.6 \%$ of the sample in Cendres and only $16.9 \%$ in Malladetes (if we do not take chips into account). Unlike the Malladetes assemblage, the faunal accumulation at Cendres has mainly an anthropic origin (ungulates, small prey and carnivores). The different geographic locations of the sites and their functionalities, the type of occupations and the conservation of each assemblage can explain these differences. Perhaps, the minor importance of leporids could be derived from a different occupation model, one with a logistical character, of a short duration and focused mainly in the obtention of medium-sized ungulates.

\section{Cultural Sequence Overview}

If we consider the chronology of the basal levels (XV-XVI) and assess them in light of the information provided by the 1940s campaigns, they open an interesting unknown about the beginning of the human presence at this site, insofar as they refer to a context that both in the southern region (Zilhão et al. 2017) and in the northern zone (Morales et al. 2019) points to the Middle Palaeolithic, at least for level XVI. In the immediate regional context, only the AMS uncalibrated date from the Middle Palaeolithic level D1 of Beneito provides a chronological frame of reference that can support its cultural attribution although its wide uncertainty band must be taken into account $(46,098-$ 38,433 cal BP). Another reference level is IL4 of La Boja, whose date $(41,800-$ 38,400 cal BP) has been considered as a terminus post quem of the Aurignacian sequence, referring here to an archaeologically sterile level in which an intrusive assemblage of the Evolved Aurignacian was redeposited (Zilhão et al. 2017); also, the AS1 subcomplex of Cueva Antón can be dated between 37,700 and 35,100 cal BP and be associated with a Middle Palaeolithic industry (Zilhão et al. 2016). Finally, level IV of Cova Foradada (Calafell), corresponding to a Chatêlperronian industry, has been dated between 42,200 and 35,700 cal BP, and at the same site, the Early Aurignacian level IIIc has been dated between 39,400 and 35,600 cal BP (Morales et al. 2019). The implications of the chronological context will be assessed when we address the cultural ascription of levels XV and XVI in the next section.

In general terms, the dates obtained in the VII-XIVA levels of Malladetes coincide with those obtained for the EUP at Cendres and La Boja, confirming the entity of the Aurignacian-Gravettian sequence from a regional perspective. Furthermore, the high 
number of dates in these three sequences is a good starting point to organise the EUP at a regional scale. On the one hand, the Cendres series stands out with a total of 22 dates: 15 of the Gravettian, dated between 31,000 and 25,300 cal BP, and seven of the Aurignacian, dated between 35,300 and 30,800 cal BP (Villaverde et al. 2019). On the other hand, the La Boja site has a total of 19 radiocarbon dates for the OH12-20 series: four of the Gravettian, dated between 31,500 and 27,400 cal BP, and 15 of the Aurignacian, dated between 38,400 and 33,900 cal BP (Zilhão et al. 2017).

Concerning the EUP sequence, the tools correlate perfectly with the series of dates obtained for the whole sequence, with an absence of typical Gravettian-backed elements in the lower levels (XII-XIVA) and their presence from level XI onwards. As also observed in Cendres, Aurignacian levels of Malladetes seem to indicate the scant importance of human occupations during this period. Moreover, it should be noted that in Parpalló, there are no materials older than the Gravettian period. In any case, and regardless of the scarcity of lithic evidence, levels XII-XIVA of Malladetes and XVIC$\mathrm{D}$ of Cendres indicate the presence of the Aurignacian industry in this regional context between 38,800 and 33,700 cal BP.

If we compare the Aurignacian sequence of Malladetes with that of Cendres, both sites show a greater density of lithic remains at the top of the Aurignacian sequence (level XII at Malladetes and XVIC at Cendres) than in the underlying Aurignacian levels (XIII and XIVA at Malladetes and XVID at Cendres). The number of lithic materials also noticeably increases when reaching the upper Aurignacian levels in Beneito (level B8) and La Boja (levels OH15-17). Level VIII of Cova Foradada (Xàbia) has been interpreted as the beginning of the Aurignacian occupation of the site and dated at 33,900 $\pm 310 \mathrm{BP}$, and human evidence in this level is limited to some bone fragments, burned and with anthropogenic marks, but with hardly any lithic industry (Casabó 2001). Their chronological interval fits with the dates of level XIVA of Malladetes, confirming a pattern of short and poor occupation events during the start of the Evolved Aurignacian in the region. An interesting aspect of Malladetes is the dissociation between the large amount of evidence of combustion from level XIII and the scant documentation of retouched lithic material, which consists of a single Dufour bladelet. Human occupation is also confirmed by the presence of some red deer remains with anthropogenic marks, suggesting that the small excavated area would not have been conducive to tasks other than consumption and would be associated with occupations that could have been especially short-lived and linked to small groups.

The main limitation in the organisation of EUP of Malladetes is the limited number of retouched lithic material recovered at some levels, especially in those ascribed to the Aurignacian. This situation exists in other Iberian Mediterranean sites, such as in the Early Aurignacian of Cova Foradada (Calafell) with 75 pieces, among which 10 are bladelets and two are Dufour types, or in levels OH18-20 of La Boja, with 19 retouched pieces, six of them being bladelets. Therefore, an approximate sequencing of the phases that constitute the Aurignacian is only possible based on the combination of the industrial and chronological data.

In relation to the Aurignacian cultural attribution, based on the presence of Dufour bladelets found in levels XII-XIVA, we can affirm that in technological and typological terms, these levels cannot be attributed to the Early Aurignacian. The Roc-deCombe subtype of Dufour bladelets is present in levels XII and XIII and a bladelet of Dufour type, with alternating retouch on the left edge, is documented in level XIVA. 
Moreover, the chronology of level XIVA is in line with an Evolved Aurignacian attribution. In the regional context, the number of Dufour bladelets is usually higher in the upper levels of the Aurignacian: it is the case for Beneito level B8, where Dufour bladelets are found twice as much as in level B9, or even for levels $\mathrm{OH} 15$ and $\mathrm{OH} 17$ of La Boja and level XVIC of Cendres. Finally, the presence of some backed microliths - with a short abrupt retouch and limited to the very edge, which are not typical of the Gravettianin the Evolved Aurignacian of La Boja (levels OH15 and OH16) and in the level B8 of Beneito has been considered an argument to sustain a transition to the regional succeeding Gravettian period. However, backed microliths are not documented in level XII of Malladetes and neither in level XVIC of Cendres. Regarding the possible persistence of some Dufour-type bladelets in the Gravettian, this situation was not documented in level XI of Malladetes, in contrast with level XVIB of Cendres (Villaverde et al. 2019) and the Early Gravettian of Beneito (level B7b) (Iturbe et al. 1993).

The continuity of the Roc-de-Combe subtype of Dufour bladelets until the top levels of the Aurignacian sequence in Malladetes, Cendres, La Boja or Beneito makes the distinction between Evolved and Late Aurignacian difficult in techno-typological terms. Only the position of the different levels in the sequence and the dates obtained from them allow us to propose this succession, which, in the Valencian area, lacks indicators similar to those pointed out in the Late Aurignacian of Pego do Diabo (Zilhão et al. 2010). Moreover, the chronological correlation between level XII of Malladetes, levels OH15-16 of La Boja and level XVIC of Cendres point to them being Late Aurignacian. This same hypothesis could be established for level B8 of Beneito.

To conclude, three particularly noteworthy aspects of the Aurignacian levels of Malladetes should be highlighted:

- First, it is remarkable that so few lithic remains were found in level XIII in contrast to the repeated documentation of combustion structures throughout its entire formation. This small amount of lithic remains may be partly due to a loss of material from the 1970 campaign or to a lack of correspondence between the location of the activity or consumption areas and the areas in which the combustion structures are documented. Even so, if we consider the number of recovered pieces (without taking into account chips), level XIII of sector Z-III (2016-2017) only reaches half the number recorded in level XII, despite being thicker. However, as indicated above, the amount of bone remains at level XIII is much larger than at the other two Aurignacian levels (XII and XIVA), and the anthropogenic processing marks confirm that some of the documented remains were linked to human activity.

- Second, the documentation of human consumption of birds and possibly small rodents at level XIVA is of great interest. It is the first level of the Aurignacian sequence at the site where the presence of both anthropogenic and nonanthropogenic modifications suggest mixed bone accumulations. However, the scarce presence of anthropogenic modifications confirms the idea of shortlived human occupations. This is further supported by the absence of thermally altered remains and the small number of lithic pieces in relation to the thickness of the level. The study of plant macroremains, microfauna and birds points to the cold nature of the climate during their formation. 
- Third, as already been discussed, before the occupation hiatus marked by level XIVB, evidence of human dwelling at Malladetes has been established in underlying levels XV and XVI. This, together with the significant sedimentary thickness, has shown a correlation between the two Aurignacian bone artefacts recovered in the 1947 and 1948 campaigns in sectors D and E and those from levels XII-XIVA of the sequence.

Regarding the Gravettian levels, the results obtained in the 2016-2017 campaigns only enable the study of levels IX-XI. The excavation of levels VII and VIII has not provided lithic industry, and we have only used materials recovered in 1970, when the sieving method could introduce some bias, which could explain the smaller number of microlaminar blanks. Although no backed pieces were documented in level VII, a microgravette was identified in level VIII. A comparison with the materials from the 1940s will help overcome this shortage of material; in any case, dates obtained for level VII are consistent with its attribution to the Gravettian.

From a regional perspective, the Early Gravettian levels OH14 and OH13 of La Boja are especially poor in retouched materials, with only a basal fragment of a microgravette and a dihedral déjété burin (Zilhão et al. 2017), whereas the Middle Gravettian is characterised by a greater density of lithic material and clearer evidence of the importance of the occupations, just as in levels X-VII of Malladetes. This is evident both in level XVIA of Cendres and in level B7 of Beneito. Level XI of Malladetes seems to correlate with the Early Gravettian based on its position in the sequence, its chronology and its density of materials, here probably with a more sporadic occupation pattern and with less importance than in the rest of the Gravettian sequence. The larger number of carnivore marks in the recovered bone remains suggests frequent human abandonment periods during which the cave may have been frequented by carnivores (see Suppl. Material Table 3: Faunal remains).

In any case, the reduced presence of local raw materials, the fragmentation of the chaîne opératoire, the dimensions and characteristics of the documented combustion structures and the scarcity of faunal remains with anthropogenic processing marks are aspects consistent with the idea that the occupations during the Aurignacian could be short-lived, were performed by small groups and were more spaced out over time than in the Gravettian during the period in which the respective levels were formed. In this regard, the low proportion of bone remains with anthropogenic marks with respect to those with carnivore modifications is particularly significant. Level XI, which coincides with the beginning of the Gravettian, constitutes an inflexion point, in sequential terms, that continues for levels VII$\mathrm{X}$. Nevertheless, although these levels have more anthropic evidence, they are still characterised by a sporadic and short duration occupation model, even though the hearths of levels VIII and IX point to combustion episodes of certain intensity based on their thickness and the presence of basal sedimentary rubefaction. The limited excavated space and the absence of information on the spatial distribution of materials from older campaigns prevent more of a discussion about this; therefore, the site's function in the territorial context remains unknown. Since the Gravettian occupation in Parpalló was not particularly important, Malladetes cannot be considered a specialised camp related to Parpalló. The Gravettian levels of Malladetes seem consistent with a logistical 
settlement with a hunting component overshadowing the residential one, and the place of the base camp in its area still remains undiscovered.

At Malladetes, Gravettian levels VII-X coincide with a substantial presence of backed tools, especially in level X. Compared with Cendres, the most notable variation is in the proportion of endscrapers and burins, the former of which are much more predominant at Malladetes. However, the technological and typological features of projectiles and splintered pieces are relevant to their cultural correspondence, as well as the presence of ornaments.

Regarding the 1976 publication of Fortea and Jordá, the most important novelty in studying Malladetes has been to characterise level XI, which was poorly defined in industrial terms in the 1970 excavation. This level fits into the Gravettian complex and, more specifically, the Early Gravettian. Indeed, it is characterised by the presence of Gravette points, truncations, splintered pieces and yet a lack of documentation of endscrapers and burins. The comparison with level XVIB of Cendres is highly conditioned by the small amount of the retouched lithic material identified, and although it coincides in terms of the significant amount of backed tools, there is a considerable difference in the importance of microlaminar tools.

Generally speaking, the chronological interval into which the Early and Middle Gravettian at Malladetes falls is 30,800-27,300 cal BP, clearly corresponding to the similar Gravettian sequence of La Boja, which is also limited to the Early and Middle Gravettian, dated between 31,500 and 27,400 cal BP. In turn, the first two Gravettian phases of the Cendres sequence (levels XVIB and XVIA) can be dated between 31,000 and 27,400 cal BP. On the other hand, there is no disagreement between these dates and those obtained at other Gravettian sites, such as Barriada (Fernández-López de Pablo et al. 2014) or Comte (Casabó et al. 2017), or more distant sites, such as those of Palomar (De la Peña and Vega 2013), Nerja (Jordá and Aura Torsosa 2008) or Bajondillo (Cortés-Sánchez et al. 2019), although in the latter case, as for Gravettian level IIIn of Foradada (Morales et al. 2019), the dates obtained are somewhat older.

Although it is not possible to make a detailed industrial characterisation of the different Aurignacian and Gravettian phases based on a study of the materials from sector Z-III, they provide some qualitative industrial information. Data are consistent with the nearby site of Cendres (about $55 \mathrm{~km}$ away), confirming the importance, in typological and technological terms, of the phases corresponding to the Aurignacian and Gravettian in the EUP sequence, here providing interesting palaeoenvironmental data that complement those obtained in the 1970 campaign.

Finally, radiocarbon dates from Malladetes allow their correlation with the $\delta^{18} \mathrm{O}$ record from the NGRIP2 core (Rasmussen et al. 2014; Seierstad et al. 2014). The occupation periods of the cave coincide with the stadial moments of the Last Glacial (Fig. 7). From the bottom to the top, the sequence is as follows:

- Levels without cultural ascription: Level XVI (44.2-42.1 Kyrs cal BP) was formed during the cold stadials GS-11 and/or GS-12. The human occupation of level XV (41.4-39.9 Kyrs cal BP) probably took place during GS-10.

- $\quad$ The Aurignacian levels coincide with cold stadials, though level XIVA (39.1-36.3 Kyrs cal BP) could be chronologically correlated with some moments of GI- 8 . However, because the identified flora, micromammals and avifauna are typically 
found in cold conditions, we are inclined to think that this level was formed during the cold periods of GS-8, much like levels XIII and XII, which would correspond with this stadial or GS-7.

- Following their radiocarbon data, the Gravettian levels (XI, X, IX and VII) were formed during GS-5.1 and GS4.

\section{Difficulties in the Cultural Characterisation of the Basal Levels (XIVB-XVI)}

By excavating sector Z-III of Malladetes, the archaeological sequence from 1970 has been extended, including the new levels XIVB to XVI. The presence of hearths and bones with anthropogenic marks evince occasional human occupation although the absence of diagnostic lithic materials hampers the cultural attribution of the levels. These issues make necessary an examination of these basal levels of Malladetes in detail, here comparing the information provided by the recent excavations with that gleaned from the 1946-1949 campaigns.

In sector Z-III, level XIVB is associated with a phase probably without human presence because no lithic remains were found, not even chips, and there is a total of 15 bone remains, most of them from lagomorphs and without signs of butchery. Likewise, no evidence of combustion was documented. Only two remains of birds with anthropogenic marks and some pieces of wood charcoal contradict this idea although it cannot be ruled out that they could come from the upper level. Level XIVB, therefore, marks a break between the lower levels and the well-dated Aurignacian level XIVA.

The upper part of level XV shows evidence of combustion, and a bone with anthropogenic marks and another with thermal alterations were identified in this unit. However, no lithic reduction material was found, and only one small and highly concreted pebble could have been taken to the site during its occupation.

Finally, in level XVI, although the lithic industry is limited to two chips, human presence is confirmed by bones with anthropogenic marks and that are thermally altered, which can be associated with a combustion structure at the basal part of the level.

In short, the basal sedimentary sequence in sector Z-III of Malladetes has a thickness of approximately $95 \mathrm{~cm}$, most $(85 \mathrm{~cm})$ with very scarce but unequivocal anthropic evidence. In these basal units, the bone remains seem to follow a mixed accumulation pattern that is associated with periods with short-lasting human occupations of small groups and periods with carnivore presence. This interpretation is supported by the documentation of carnivore activity over some bones and the scant anthropic evidence linked to combustion structures and the butchery of some faunal remains, mainly medium and large ungulates and, in one particular case, a carnivore that also presents superimposed marks of a nonanthropic origin.

The scarce presence of lithic industry in the basal levels of sector Z-III hinders their cultural attribution. The obtained radiocarbon dates and the assessment of the materials from the 1940s campaigns could shed some light on this issue.

The 1940s campaigns reached a greater depth than the recent excavations although they did not reach the base of the fill (Suppl. Material 8: Excavation of basal levels in 1940s campaigns). In sectors E and D, below the massive-based antler points, which are attributed to the Aurignacian, $1.5 \mathrm{~m}$ and $40-60 \mathrm{~cm}$ were excavated, respectively. 
Because of the scarcity of lithic material in these basal layers, little attention was paid to the vertical distribution of the remains. The excavation of very thick spits probably led to mixtures of materials of different cultural periods. The vagueness with which these spits are described in the diaries does not help to establish whether some were actually sterile and whether there were materials of a typology that would suggest the presence of a Middle Palaeolithic phase lying underneath the Aurignacian occupation phase, as would be expected.

Considering the chronology obtained for levels XV (between 41,100 and 39,400 cal BP) and XVI (between 44,600 and 41,900 cal BP), and the 38,396-34,165 cal BP interval of La Boja's Evolved Aurignacian (levels OH18-OH20), when reviewing the archaeological remains of the 1940s campaigns, our attention was directed at establishing whether there could be any indicator of Middle Palaeolithic human presence at the site. In sectors D and F, there are some lithic pieces that are not at odds with the Middle Palaeolithic: two sidescrapers, two denticulate pieces and one discoid core (Suppl. Material 8: Excavation of basal levels in the 1940s campaigns).

In short, in the areas where a certain depth was reached, there is a continuity of human presence down to the lowest excavated level and a scarcity of material in the deeper layers of sector Z-III and in other sectors. In this context, the lack of laminar production and the documentation of modified tools not at odds with the Middle Palaeolithic are both consistent with the chronology obtained in level XV and particularly with level XVI of sector Z-III. A similar situation has been pointed out for the basal level XVII of Cendres, where no blades or bladelets were found and where the lithic material fits with a system of flake production. Unfortunately, all attempts to date this level have been unsuccessful, leaving their cultural attribution open.

Regarding the chronological framework of these two levels, it is necessary to remember that the Early Aurignacian level IIIc of Cova Foradada (Calafell) has been dated to the 39,400-35,600 cal BP interval and the Chatêlperronian level IV to the 42,200-38,500 cal BP interval (Morales et al. 2019), opening the possibility that Neanderthals were present in this region during the formation of levels XV and XVI of Malladetes. Only the recent attribution of level Bj13 of Bajondillo to the Early Aurignacian offers a chronological framework to an Early Aurignacian at the south of the Ebro basin (Cortés-Sánchez et al. 2019), but no characteristic techno-typological material has been described which could corroborate this cultural attribution (Anderson et al 2019; De la Peña 2019).

With the currently available information, we lack evidence of an Early Aurignacian in the Mediterranean coastal corridors that would support the rapid expansion of modern human populations south of the Ebro basin, an idea that has been proposed to sustain the Early Aurignacian chronology of level Bj13 of Bajondillo (CortésSánchez et al. 2019): the levels XVII of Cendres and XV-XVI of Malladetes are not characterised by an Upper Palaeolithic industry, and the scarcity of anthropic evidence suggests that human occupation in this region was rare between the 44,600 and 38,800 cal BP interval.

In these two levels (XV and XVI), the absence of diagnostic lithic industry forces us to take into consideration the available information of those sites where the Middle Palaeolithic to EUP succession has been documented. In Beneito, the Aurignacian levels B9 and B8 are separated from those of the Middle Palaeolithic (levels D4-D1) 
by levels $\mathrm{C} 5-\mathrm{C} 1$, which are described as discontinuity levels. Actually, human occupation is limited to C4 and C2, coinciding with two combustion structures (Iturbe et al. 1993). These two levels have a limited number of lithic materials (27 and 70 remains, respectively), including pieces techno-typologically characteristic of the Upper Palaeolithic and perfectly consistent with an Aurignacian attribution (bladelets, carinated endscraper-cores and laminar debitage). There are two dates from level $\mathrm{C} 4$, the deepest unit, that have clearly opposing results: one of conventional C14 of 26,040 \pm $890 \mathrm{BP}$ and the other AMS uncalibrated of 33,900 $\pm 1,100 \mathrm{BP}$. However, as a result of subsequent excavations (Domenech 2005), it has been suggested that these levels correspond to a phase without human presence that includes redeposited Middle Palaeolithic materials, so it is not appropriate to consider them in cultural terms. Level D1, corresponding to the end of the Middle Palaeolithic at the site, presents the same problems regarding the dates depending on the dating system, with uncalibrated results of $30,160 \pm 680 \mathrm{BP}$ and 38,800 $\pm 1,900 \mathrm{BP}$, respectively. Even though the validity of these dates has been criticised based on the opposing results between AMS dates and conventional C14 dates from the same sequence (Zilhão 2006), the chronology of level D1, here taking into account the wide uncertainty band, refers to an interval similar to level XVI of Malladetes.

La Boja and Finca de Doña Martina have been recently excavated, and a rich sequence including the Middle Palaeolithic and EUP has been documented, showing an important series of dates (Zilhão et al. 2017) that make the characterisation and chronostratigraphical contextualisation of both periods easier. The Middle Palaeolithic is dated beyond $44 \mathrm{ka}$ and the beginning of the Upper Palaeolithic in the interval between 38.2 and $34.9 \mathrm{ka}(\mathrm{OH} 18-\mathrm{OH} 20)$. In the nearby site of Cueva Antón, the earliest possible age of the latest Mousterian level I-k is 37,100 ka (Zilhão et al. 2017).

Level VI of Palomar was dated to 33,110-31,950 cal BP and considered the end of the Middle Palaeolithic in this site (De la Peña 2012b). Nevertheless, this level includes some materials with clearly Upper Palaeolithic attribution, so the obtained date could be related to these materials (Villaverde et al. 2019). Over this unit, levels V-III can clearly be attributed to the Gravettian based on the important assemblage of backed pieces and consistent dates with this ascription.

El Niño presents a succession of various Middle Palaeolithic levels (III-XI) and one level documented in the inner zone of the cave and dated in the Upper Palaeolithic although without diagnostic lithic material. The Middle Palaeolithic of levels III-IV, with 74 lithic pieces, four of them retouched, has provided a date of 33,470-31,975 cal BP. Researchers that have reviewed the sequence have stated that 'It has a low reliability because of a possible rejuvenation of the samples because of the carbonate absorption' (García-Moreno et al. 2014: 235), whereas level XI has provided a date of 55,500 years. Moreover, the sample from the test pit at the base of Palaeolithic paintings provides a result of 27,977-26,934 cal BP (Gárate and Garcia-Moreno 2011) and is related to the end of the Gravettian period in Valencia and Murcia.

The sequence of Bajondillo presents various EUP and Middle Palaeolithic levels. Level $\mathrm{Bj} 13$, which was interpreted as a phase characterised by a mix with material from Middle Palaeolithic level Bj14 (Cortés-Sánchez 2007), has been recently dated to the interval 44,778-40,517 cal BP (Cortés-Sánchez et al. 2019). The authors consider that the date is consistent with the scarce and not much diagnostic Upper Palaeolithic materials, so it constitutes proof of the early arrival of the Aurignacian and AMH to 
the South of the Iberian Peninsula. Level Bj14 is dated to 50-46 cal ka BP according to the results presented in the same paper.

On the contrary, the sequence of Sima de las Palomas de Teba presents two phases that can be related to the Middle Palaeolithic, and it is composed of units 9 and 10. Its end is dated in level 8, corresponding to a partial roof collapse in the interval between $40.5 \pm 3.4 \mathrm{ka}$ and $39.8 \pm 2.4 \mathrm{ka}$. Above these levels, unit 6 'contains a comparatively large number of lithics of clearly Mousterian affinity’ (Kehl et al. 2016, pp. 328-29), the chronology of which remains undetermined; however, it would be comprised between the previous dates and those of unit 5 , dated to $27.9 \pm 4.5-27.0 \pm 2.3 \mathrm{ka}$. Both this latter unit and unit 4 have provided very scarce lithic material ( 4 and 7 pieces, respectively), which is not diagnostic for a cultural attribution, though they could correspond to the Upper Palaeolithic. Unit 6 could have formed sometime after $\sim 40 \mathrm{ka}$ based on this evidence (Kehl et al. 2016).

Finally, Gorham's Cave also presents the Middle Palaeolithic-EUP succession, which has been a debated question (Pettitt and Bailey 2000; Wood et al. 2013; Zilhão and Pettitt 2006; Zilhão et al. 2017). The chronological extension of the Middle Palaeolithic is partly influenced by the possibility that some materials of Waetcher's excavations from levels D and F correspond to the EUP. Although data are not sufficient for specifying the cultural attribution of these levels and of level F, even casting doubts on its degree of integrity (Barton and Jennings 2012), a critical review of the available dates does not contradict the existence of a generic EUP in the sequence of the external part of the site (Zilhão and Pettitt 2006).

Regarding the northern part of the Mediterranean region, the Early Aurignacian is documented in L'Arbreda (Wood et al. 2014), Romaní (Bischoff et al. 1994) and Cova Foradada (Calafell) (Morales et al. 2019) in the latter preceded of a Chatêlperronian level, and in other assemblages whose stratigraphies include the Middle Palaeolithic and the EUP, such as Cova Gran (Mora et al. 2018; Martínez-Moreno et al. 2019). The chronological framework for the end of the Middle Palaeolithic north of the Ebro River is dated between 43.8 and $41.8 \mathrm{ka}$ cal BP, and the Protoaurignacian/Early Aurignacian of L'Arbreda and Romaní is dated between 42.3 and $41 \mathrm{ka}$ cal BP (Morales et al. 2019).

Taking into account the regional chronological framework, it is unlikely that level XVI of Malladetes could correspond to a period different than the Middle Palaeolithic. Despite the industrial nondefinition, the coherence between the combustion evidence and the anthropogenic marks on some bones suggest that in that moment, Neanderthal groups were in this area, even when a territorial occupation system cannot be characterised with the available information. In any case, as indicated with respect to the other areas, it is impossible that these occupations were not related with a sufficient population for maintaining the social and reproductive networks. Level XV can be placed in a more ambiguous temporal interval if the attribution to the Early Aurignacian of the date of level $\mathrm{Bj} 13$ of Bajondillo is accepted although it is very similar to the date of the formation of level IL4 of La Boja, so its attribution to the Middle Palaeolithic cannot be rejected. Although we are cautious and wish to maintain the cultural nondefinition of this level, with the available information, it is unreasonable to claim that this level represents proof of the early beginning of EUP in the region. The abandonment period represented by level XIVB does not support its ascription to the beginning of the EUP in the region. 


\section{Conclusions}

The archaeological sequence of Cova de les Malladetes has traditionally played a leading role in structuring the Upper Palaeolithic of the central Iberian Mediterranean region. Providing some fundamental aspects, previous research gave a stratigraphic and palaeoenvironmental framework for this period, revealed the existence of an EUP sequence with an important presence of the Gravettian preceded by a technotypologically ill-defined lithic industry, but with some bone points of clear Aurignacian ascription, and assessed the regional patterns of occupation in relation to the Cova del Parpalló.

The new excavations carried out in 2016-2017, whose results are presented in the current work, have shown some important aspects related to the EUP, especially concerning the Aurignacian, and have provided additional palaeoenvironmental and chronological information on the EUP.

The recovered lithic materials have confirmed the Aurignacian occupation of the site at levels XII, XIII and XIVA, all of them characterised by the presence of Dufour bladelets and the absence of typically backed Gravettian laminar tools. Considering their chronology, it could be possible to correlate level XII with the Late Aurignacian and levels XIII and XIVA with the Evolved Aurignacian. These results are connected with those obtained at other sites of the same territorial framework (Cendres, Foradada - of Xàbia - and Beneito) or in more meridional territories (La Boja and Bajondillo).

Another interesting result has been to specify the importance of the Gravettian occupation in levels VII-XI. First, the imprecise ascription of level XI in the 1970 excavation has been clarified with diagnostic material recovery in 2016-2017, here finding some backed tools, splintered pieces and truncations, a material not documented in 1970. Based on the chronology and diagnostic techno-typological characteristics, this level could be included in the Early Gravettian. Second, a more intense occupation can be established during this period based on the increase of lithic and faunal remains. However, hearths were not documented at level XI in the 1970 or 2016-2017 campaigns. In any case, evidence for a more intense occupation, either as a consequence of a greater number of people, a longer duration of stay or a greater frequentation, can be proposed for levels XI and X. For the first time in the sequence, the number of anthropogenic marks on the bones is greater than that of the carnivore marks.

As in the other regional sites with Middle Gravettian occupations, this phase seems to be associated with an increase of archaeological evidence, suggesting a certain population density. Recently, the possibility that human occupation was less important during the final Middle Palaeolithic and Early Upper Palaeolithic in the Iberian Mediterranean region was suggested (Morales et al. 2019). Both the Cendres and Malladetes sequences suggest a similar idea concerning the Aurignacian, but the Early and Middle Gravettian offers more quantitative variation. A simple interpretation of this variation seems problematic: Malladetes, which must be a temporal specialised camp, presents an important increase of lithics and anthropic evidence during the Early Gravettian, while Cendres, for both the Early Gravettian and the Late Gravettian, presents fewer lithics and faunal remains, which seems to indicate a lower occupation or a change in the site's function. The currently available dataset is too small and imprecise for such assessments to be made safely, even in reduced regional terms. 
Finally, the chronology and the archaeological materials (hearths and faunal remains with anthropogenic marks) documented in levels XV and XVI suggest that the Evolved Aurignacian of level XIVA was preceded by a cultural undetermined human presence at the site. Considering the dates obtained at the Cova Foradada (Calafell), La Boja and Cueva Antón sites, the most parsimonious explanation is that both levels could be related to a Middle Palaeolithic presence in the region. Only level 13 of Bajondillo opens up the possibility to the chronological ascription of level XV of Malladetes to the EUP, although this attribution is extremely forced because of the absence of lithic industry. The chronology of level XVI leaves this unit less vague because there is no chronological evidence in the southern Mediterranean Basin that suggests a documentation of the EUP for these dates. Despite the vagueness of the cultural ascription of level $\mathrm{XV}$, it is noticeable that there is not a large chronological gap between the occupation of the basal levels XV and XVI and the beginning of the Aurignacian sequence, which has implications in the characterisation of the Middle to Upper Palaeolithic transition at the regional scale.

Supplementary Information The online version contains supplementary material available at https://doi.org/ 10.1007/s41982-021-00081-w.

Funding The field and laboratory research was supported by the Spanish Ministerio de la Ciencia e Innovación (HAR2017-85153P) and by the Generalitat Valenciana (PROMETEO/2017/060).

\section{Declarations}

Conflict of Interest The authors declare no competing interests.

Open Access This article is licensed under a Creative Commons Attribution 4.0 International License, which permits use, sharing, adaptation, distribution and reproduction in any medium or format, as long as you give appropriate credit to the original author(s) and the source, provide a link to the Creative Commons licence, and indicate if changes were made. The images or other third party material in this article are included in the article's Creative Commons licence, unless indicated otherwise in a credit line to the material. If material is not included in the article's Creative Commons licence and your intended use is not permitted by statutory regulation or exceeds the permitted use, you will need to obtain permission directly from the copyright holder. To view a copy of this licence, visit http://creativecommons.org/licenses/by/4.0/.

\section{References}

Anderson, L., Reynolds, N., \& Teyssandier, N. (2019). No reliable evidence for a very early Aurignacian in Southern Iberia. Nature Ecology \& Evolution, 3(5), 713-713. https://doi.org/10.1038/s41559-019-0885-3.

Andrews, P. (1990). Owls, caves and fossils. London: British Museum of Matural History.

Andrews, P., \& Evans, E. M. N. (1983). Small mammal bone accumulations produced by mammalian carnivores. Paleobiology, 9(3), 289-307. https://doi.org/10.1017/S0094837300007703.

Aparicio Santos, R. (2002). Zorzal Charlo (Turdus viscivorus). Biodiversia. Plataforma del inventario Español del Patrimonio Natural y de la Biodiversidad, 448-449.

Arsuaga, J. L., Villaverde, V., Quam, R., Gracia, A., Lorenzo, C., Martínez, I., \& Carretero, J.-M. (2002). The Gravettian occipital bone from the site of Malladetes (Barx, Valencia, Spain). Journal of Human Evolution, 43(3), 381-393. https://doi.org/10.1006/jhev.2002.0579. 
Asouti, E., Ntinou, M., \& Kabukcu, C. (2018). The impact of environmental change on Palaeolithic and Mesolithic plant use and the transition to agriculture at Franchthi Cave, Greece. PLOS ONE, 13(11), e0207805. https://doi.org/10.1371/journal.pone.0207805.

Aura Torsosa, J. E., Carrión, Y., Estrelles, E., \& Jordà, G. P. (2005). Plant economy of hunter-gatherer groups at the end of the last Ice Age: plant macroremains from the cave of Santa Maira (Alacant, Spain) ca. 12000-9000 b.p. Vegetation History and Archaeobotany, 14(4), 542-550. https://doi.org/10.1007/ s00334-005-0002-1.

Aura Tortosa, J. E., Jordá, J. F., Pérez-Ripoll, M., Badal, E., Avezuela, B., Morales Pérez, J., et al. (2012). El corredor costero meridional: los cazadores gravetienses de la cueva de Nerja (Málaga, España). In C. de la Heras, J. A. Lasheras, A. Arrizabalaga, \& M. de la Rasilla (Eds.), Pensando el Gravetiense: nuevos datos para la región cantábrica en su contexto peninsular y pirenaico (Vol. 23, pp. 104-113). Madrid: Ministerio de Educación, Cultura y Deporte.

Badal, E., \& Martínez Varea, C. M. (2018). Different parts of the same plants. Charcoals and seeds from Cova de les Cendres (Alicante, Spain). Quaternary International, 463(B), 391-400. https://doi.org/10.1016/j. quaint.2016.12.020.

Bailey, G. N., \& Davidson, I. (1983). Site exploitation territories and topography: two case studies from palaeolithic spain. Journal of Archaeological Science, 10(2), 87-115. https://doi.org/10.1016/03054403(83)90044-4.

Baines, J. A., Riehl, S., Conard, N., \& Zeidi-Kulehparcheh, M. (2015). Upper Palaeolithic archaeobotany of Ghar-e Boof cave, Iran: a case study in site disturbance and methodology. Archaeological and Anthropological Sciences, 7(2), 245-256. https://doi.org/10.1007/s12520-014-0191-6.

Barton, R. N. E., \& Jennings, R. P. (2012). The lithic artefact assemblages of Gorham's Cave. In R. N. E. Barton, C. B. Stringer, \& J. C. Finlayson (Eds.), Neanderthals in context. A report of the 1995-1998 excavations at Gorham's and Vanguard Caves, Gibraltar (Vol. 75, pp. 151-187). Oxford: University School of Archaeology.

Barton, C. M., Villaverde, V., Zilhão, J., Aura Torsosa, J. E., Garcia, O., \& Badal, E. (2013). In glacial environments beyond glacial terrains: human eco-dynamics in late Pleistocene Mediterranean Iberia. Quaternary International, 318, 53-68. https://doi.org/10.1016/j.quaint.2013.05.007.

Behrensmeyer, A. K., Gordon, K. D., \& Yanagi, G. T. (1986). Trampling as a cause of bone surface damage and pseudo-cutmarks. Nature, 319(6056), 768-771. https://doi.org/10.1038/319768a0.

Bicho, N., Marreiros, J., Cascalheira, J., Pereira, T., \& Haws, J. (2015). Bayesian modeling and the chronology of the Portuguese Gravettian. Quaternary International, 359-360, 499-509. https://doi.org/ 10.1016/j.quaint.2014.04.040.

Bicho, N., Cascalheira, J., \& Gonçalves, C. (2017). Early Upper Paleolithic colonization across Europe: time and mode of the Gravettian diffusion. PLOS ONE, 12(5), e0178506. https://doi.org/10.1371/journal.pone.0178506.

Biedma, L., Román, J., Calzada, J., Friis, G., \& Godoy, J. A. (2018). Phylogeography of Crocidura suaveolens (Mammalia: Soricidae) in Iberia has been shaped by competitive exclusion by C. russula. Biological Journal of the Linnean Society, 123(1), 81-95. https://doi.org/10.1093/biolinnean/blx126.

Binford, L. (1981). Bones: ancient men and modern myths. New York: Academic Press. https://doi.org/10. 1016/C2013-0-07180-0.

Bischoff, J. L., Ludwig, K., Garcia, J. F., Carbonell, E., Vaquero, M., Stafford, T. W., \& Jull, A. J. T. (1994). Dating of the basal Aurignacian sandwich at Abric Romani (Catalunya, Spain) by radiocarbon and uranium-series. Journal of Archaeological Science, 21(4), 541-551. https://doi.org/10.1006/jasc.1994.1053.

Blanco Aguiar, J. A., Virgós, E., \& Villafuerte, R. (2002). La perdiz roja (Alectoris rufa). Biodiversia. Plataforma del inventario Español del Patrimonio Natural y de la Biodiversidad., 212-213.

Bradtmöller, M., Pastoors, A., Weninger, B., \& Weniger, G.-C. (2012). The repeated replacement modelrapid climate change and population dynamics in Late Pleistocene Europe. Quaternary International, 247, 38-49. https://doi.org/10.1016/j.quaint.2010.10.015.

Bradtmöller, M., Marreiros, J., Pereira, T., \& Bicho, N. (2016). Lithic technological adaptation within the Gravettian of the Iberian Atlantic region: results from two case studies. Quaternary International, 406, 324. https://doi.org/10.1016/j.quaint.2015.08.075.

Brock, F., Higham, T., Ditchfield, P., \& Ramsey, C. B. (2010). Current pretreatment methods for AMS radiocarbon dating at the Oxford Radiocarbon Accelerator Unit (Orau). Radiocarbon, 52(1), 103-112. https://doi.org/10.1017/S0033822200045069.

Bronk Ramsey, C. (2009). Bayesian analysis of radiocarbon dates. Radiocarbon, 51(1), 337-360. https://doi. org/10.1017/S0033822200033865.

Bronk Ramsey, C. (2017). Methods for summarizing radiocarbon datasets. Radiocarbon, 59(6), 1809-1833. https://oi.org/10.1017/RDC.2017.108. 
Carrión, Y., Jacob, M., Portillo, M., Pérez-Jordà, G., Peña-Chocarro, L., \& Zapata, L. (2018). The use of wild plants in the Palaeolithic and Neolithic of northwestern Africa: preliminary results from the PALEOPLANT project. In A. M. Mercuri, A. C. D’Andrea, R. Fornaciari, \& A. Höhn (Eds.), Plants and humans in the African past. Progress in African archaeobotany (pp. 146-174). Cham: Springer. https://doi.org/10.1007/978-3-319-89839-1 9.

Casabó, J. (2001). Cova Foradada (Xàbia, Alacant). In V. Villaverde (Ed.), De Neandertales a Cromañones. El inicio del poblamiento humano en las tierras valencianas (pp. 407-410). València: Servei de Publicacions de l'Universitat de València.

Casabó, J., de Boronat, J. D., Carrión, Y., Esquembre, M. A., Guillem, P. M., Martínez Valle, R., et al. (2017). New evidence of Palaeolithic rock art at the Cova del Comte (Pedreguer, Spain): results of the first surveys. Quaternary International, 432, 25-40. https://doi.org/10.1016/j.quaint.2015.12.061.

Caspar, J.-P., \& Bie, M. D. (1996). Preparing for the hunt in the Late Paleolithic camp at Rekem, Belgium. Journal of Field Archaeology, 23(4), 437-460. https://doi.org/10.1179/009346996791973747.

Chrzazvez, J., Théry-Parisot, I., Fiorucci, G., Terral, J.-F., \& Thibaut, B. (2014). Impact of post-depositional processes on charcoal fragmentation and archaeobotanical implications: experimental approach combining charcoal analysis and biomechanics. Journal of Archaeological Science, 44, 30-42. https://doi.org/10. 1016/j.jas.2014.01.006.

Coppe, J., \& Rots, V. (2017). Focus on the target. The importance of a transparent fracture terminology for understanding projectile points and projecting modes. Journal of Archaeological Science: Reports, 12, 109-123. https://doi.org/10.1016/j.jasrep.2017.01.010.

Coppe, J., Lepers, C., Clarenne, V., Delaunois, E., Pirlot, M., \& Rots, V. (2019). Ballistic study tackles kinetic energy values of Palaeolithic weaponry. Archaeometry, 64(4), 933-956. https://doi.org/10.1111/arcm.12452.

Cortés-Sánchez, M. (2007). Cueva de Bajondillo (Torremolinos). Secuencia cronocultural y paleoambiental del Cuaternario reciente en la Bahía de Málaga. Málaga: Diputación de Málaga.

Cortés-Sánchez, M., Jiménez-Espejo, F. J., Simón-Vallejo, M. D., Stringer, C., Francisco, M. C. L., GarcíaAlix, A., et al. (2019). An early Aurignacian arrival in southwestern Europe. Nature Ecology \& Evolution, 3(2), 207-212. https://doi.org/10.1038/s41559-018-0753-6.

Cramp, S., \& Simmons, K. E. L. (1994). Handbook of the birds of Europe, the Middle East, and North Africa. The birds of the Western Palearctic: terns to woodpeckers (Vol. 4). Oxford: Oxford University Press.

Cuenca-Bescós, G., Straus, L., Gonzalez Morales, M., Pimienta, J. C., \& G. (2008). Los Pequeños mamíferos de la cueva del Mirón (Ramales de la Victoria). Revista española de paleontología, 23(1), 91-126.

Cziesla, E. (1990). On refitting of stone artefacts. In E. Cziesla, S. Eickhoff, N. Arts, \& D. Winter (Eds.), The big puzzle international symposium on refitting stone artefacts (pp. 9-44). Bonn.

Davidson, I. (1976). Les Mallaetes and Monduver: the economy of a human group in prehistoric Spain. In G. Sieveking, I. H. Longworth, \& K. E. Wilson (Eds.), Problems in economy and social archeology (pp. 483-449). London: Duckworth.

Davidson, I. (1981). Late Palaeolithic economy in eastern Spain (PhD Thesis). University of Cambridge, Cambridge.

Davidson, I. (1989). La economía del final del Paleolítico en la España oriental. Serie de Trabajos Varios del SIP (Vol. 85). Valencia: Diputación de Valencia.

Davidson, I., \& García-Moreno, A. (2013). La excavación arqueológica de la cueva del niño (Ayna, Albacete) de 1973: secuencia estratigráfica y materiales. Al-Basit: Revista de estudios albacetenses, 58, 91-117.

De la Peña, P. (2012a). Flaking technology strategies in the Early Upper Palaeolithic of South Eastern Iberian Peninsula. In A. Pastoors \& M. Peresani (Eds.), Flakes not blades: the role of flake production at the onset of the Upper PalaeolIthIc in Europe (Vol. 5, pp. 51-68). Mettmann: WIssenschaftlIche SchrIften des Neanderthal Museums.

De la Peña, P. (2012b). Sobre la unidad tecnológica del Gravetiense en la Península Ibérica: implicaciones para el conocimiento del Paleolítico Superior inicial ( $\mathrm{PhD}$ Thesis). Universidad Complutense de Madrid, Madrid.

De la Peña, P. (2013a). The beginning of the Upper Paleolithic in the Baetic Mountain area (Spain). Quaternary International, 318(18), 68-96. https://doi.org/10.1016/j.quaint.2013.08.008.

De la Peña, P. (2013b). Estudio estratigráfico y tecnotipológico de los niveles basales de la cueva de Les Mallaetes (Barx, Valencia): nuevas claves para el Paleolítico superior inicial mediterráneo. Zephyrus, 71, 61-88.

De la Peña, P. (2019). Dating on its own cannot resolve hominin occupation patterns. Nature Ecology \& Evolution, 3(5), 712-712. https://doi.org/10.1038/s41559-019-0886-2.

De la Peña, P., \& Vega, G. (2013). The Early Upper Palaeolithic puzzle in Mediterranean Iberia. Quartär, 60, 85-106. https://doi.org/10.7485/QU60-4.

Domenech, E. M. (2005). La transición del paleolítico medio al superior en la Cova Beneito (Muro, Alicante): recientes aportaciones. In M. Santonja, A. Pérez-González, \& M. J. Machado (Eds.), Geoarqueología y 
patrimonio en la Península Ibérica y el entorno mediterráneo (pp. 197-203). Soria: Adema: Patrimonio. Almazán.

Domínguez-Rodrigo, M., De Juana, S., Galán, A. B., \& Rodríguez, M. (2009). A new protocol to differentiate trampling marks from butchery cut marks. Journal of Archaeological Science, 36(12), 2643-2654. https:// doi.org/10.1016/j.jas.2009.07.017.

Doyon, L. (2019). On the shape of things: a geometric morphometrics approach to investigate Aurignacian group membership. Journal of Archaeological Science, 101, 99-114. https://doi.org/10.1016/j.jas.2018.11.009.

Doyon, L. (2020). The cultural trajectories of Aurignacian osseous projectile points in Southern Europe: insights from geometric morphometrics. Quaternary International, 551, 63-84. https://doi.org/10.1016/j. quaint.2018.12.010.

Dupré, M. (1980). Análisis policlínico de sedimentos arqueológicos de la cueva de Les Malladetes (Barx, Valencia). Cuadernos de geografia, 26, 1-22.

Eixea, A., Villaverde, V., \& Zilhão, J. (2011). Aproximación al aprovisionamiento de materias primas líticas en el yacimiento del Paleolítico medio del Abrigo de la Quebrada (Chelva, Valencia). Trabajos de Prehistoria, 68(1), 65-78. https://doi.org/10.3989/tp.2011.11059.

Eixea, A., Roldán, C., Villaverde, V., \& Zilhão, J. (2014). Middle Palaeolithic flint procurement in Central Mediterranean Iberia: implications for human mobility. Journal of Lithic Studies, 1(1), 103-115. https:// doi.org/10.2218/jls.v1i1.783.

Eixea, A., Martínez-Alfaro, Á., Bel, M. Á., Roldán, C., Murcia, S., Vie, D., et al. (2020). First data on the characterization of siliceous raw materials and the catchment areas from Cova de les Malladetes. Spain: Valencia.

Fernández-Jalvo, Y., \& Andrews, P. (2011). When humans chew bones. Journal of Human Evolution, 60(1), 117-123. https://doi.org/10.1016/j.jhevol.2010.08.003.

Fernández-López de Pablo, J., Badal, E., Martínez-Ortí, A., \& Sanchis, A. (2014). Land snails as a diet diversification proxy during the Early Upper Palaeolithic in Europe. PLOS ONE, 9(8), e104898. https:// doi.org/10.1371/journal.pone.0104898.

Finlayson, C., Pacheco, F. G., Rodríguez-Vidal, J., Fa, D. A., López, J. M. G., Pérez, A. S., et al. (2006). Late survival of Neanderthals at the southernmost extreme of Europe. Nature, 443(7113), 850-853. https://doi. org/10.1038/nature05195.

Finlayson, C., Fa, D. A., Jiménez Espejo, F., Carrión, J. S., Finlayson, G., Giles Pacheco, F., et al. (2008). Gorham's Cave, Gibraltar-the persistence of a Neanderthal population. Quaternary International, 181(1), 64-71. https://doi.org/10.1016/j.quaint.2007.11.016.

Fortea, J., \& Jordá, F. (1976). La Cueva de Les Mallaetes y los Problemas del Paleolítico Superior del Mediterráneo Español. Zephyrvs, 26, 129-166.

Fortea, J., Fullola, M., Villaverde, V., Davidson, I., Dupré, M., \& Fumanal, M. P. (1983). Schéma paléoclimatique, faunique et chronostratigraphique des industries à bord abattu de la région méditerranéenne espagnole. Rivista di scienze preistoriche, 38, 21-67.

Fullola, J. M. (1979). Las industrias líticas del Paleolítico Superior Ibérico. Serie de Trabajos Varios del SIP (Vol. 60). València: Diputación de Valencia.

Fullola, J. M., Roman, D., Soler, N., \& Villaverde, V. (2007). Le Gravettien de la côte méditerranéenne ibérique. PALEO. Revue d'archéologie préhistorique, (19), 73-88.

Fumanal, M. P. (1986). Sedimentología y clima en el País Valenciano: las cuevas habitadas en el Cuaternario reciente. Serie de Trabajos Varios del SIP (Vol. 83). Valencia: Diputación de Valencia.

Gárate, D., \& Garcia-Moreno, A. (2011). Revisión crítica y contextualización espacio-temporal del arte parietal Paleolítico de la cueva de El niño (Ayna, Albacete). Zephyrvs, 68, 15-39.

García-Moreno, A., Rios Garaizar, J., Marín Arroyo, A. B., Ortíz, J. E., de Torres, T., \& López-Dóriga, I. (2014). La secuencia musteriense de la Cueva del Niño (Aýna, Albacete) y el poblamiento neandertal en el sureste de la Península Ibérica. Trabajos de Prehistoria, 71(2), 221-241. https://doi.org/10.3989/tp.2014.12132.

González-Esteban, J., \& Villate, I. (2007). Microus arvalis, Pallas, 1778. In L. J. Palomo, J. Gisbert, \& J. C. Blanco (Eds.), Atlas y Libro Rojo de los Mamíferos Terrestres de España (pp. 426-428). Madrid: Dirección General para la Biodiversidad -SECEM-SECEMU.

Guillem, P. M., \& Martínez Valle, R. (1991). Estudio de la alimentación de las rapaces nocturnas aplicado a la interpretación del registro faunístico arqueológico. Saguntum-PLAV, 24, 23-34.

Hansen, J. M. (1980). The palaeoethnobotany of Franchthi Cave, Greece. Minnesota: University Microfilms.

Iturbe, G., Fumanal, M. P., Carrión, J. S., Cortell, E., Martínez, R., Guillem, P. M., et al. (1993). Cova Beneito (Muro, Alicante): una perspectiva interdisciplinar. Recerques del Museu d'Alcoi, 2, 23-88.

Jiménez, J., Guillem, P. M., \& Martínez Valle, J. (1989). Nuevas aportaciones de distribución en el extremo meridional del sistema Ibérico de Neomys anomalus y Microtus arvalis. Medi Natural, 1(1-2), 121-123.

Jiménez, J., Monsalve, M. Á., \& Raga, J. A. (2012). Mamíferos de la Comunidad Valenciana. València: Conselleria d'Infraestructures, Territori i Medi Ambient. Generalitat Valenciana. 
Jordá, J. F., \& Aura Torsosa, J. E. (2008). 70 fechas para una cueva: revisión crítica de 70 dataciones C14 del Pleistoceno Superior y Holoceno de la Cueva de Nerja (Málaga, Andalucía, España). Espacio Tiempo y Forma. Serie I, Prehistoria y Arqueología, 1, 239-256. https://doi.org/10.5944/etfi.1.2008.1922.

Kehl, M., Burow, C., Cantalejo, P., Domínguez-Bella, S., Durán, J. J., Henselowsky, F., et al. (2016). Site formation and chronology of the new Paleolithic site Sima de Las Palomas de Teba, southern Spain. Quaternary Research, 85(2), 313-331. https://doi.org/10.1016/j.yqres.2016.01.007.

Korth, W. W. (1979). Taphonomy of microvertebrate fossil assemblages. Annals of the Carnegie Museum, 48, 235-285.

Laroulandie, V. (2005). Anthropogenic versus non-anthropogenic bird bone assemblages: new criteria for their distinction. In T. O'Connor (Ed.), Biosphere to lithosphere: new studies in vertebrate taphonomy. Proceedings of the 9th conference of ICAZ, Durham (pp. 25-30). Oxford: Oxbow Books.

Lloveras, L., Maroto, J., Soler, J., Thomas, R., Moreno-García, M., Nadal, J., \& Soler, N. (2016). The role of small prey in human subsistence strategies from Early Upper Palaeolithic sites in Iberia: the rabbits from the Evolved Aurignacian level of Arbreda Cave. Journal of Quaternary Science, 31(5), 458-471. https:// doi.org/10.1002/jqs.2869.

López-García, J. M. (2008). Evolución de la diversidad taxonómica de los micromamíferos en la Península Ibérica y cambios Paleoambientales durante el Pleistoceno Superior. (PhD Thesis). Universitat Rovira $\mathrm{i}$ Virgili, Tarragona.

Lyman, R. L. (1994). Vertebrate taphonomy. Cambridge: Cambridge University Press. https://doi.org/10. 1017/CBO9781139878302.

Lyman, R. L. (2008). Quantitative paleozoology. Cambridge: Cambridge University Press. https://oi.org/10. 1017/CBO9780511813863.

Maier, A., \& Zimmermann, A. (2017). Populations headed south? The Gravettian from a palaeodemographic point of view. Antiquity, 91(357), 573-588. https://doi.org/10.15184/aqy.2017.37.

Marreiros, J., \& Bicho, N. (2013). Lithic technology variability and human ecodynamics during the Early Gravettian of Southern Iberian Peninsula. Quaternary International, 318, 90-101. https://doi.org/10. 1016/j.quaint.2013.05.008.

Martínez, G. (2009). Human chewing bone surface modification and processing of small and medium prey amongst the Nukak (Foragers of the Colombian Amazon). Journal of taphonomy, 7(1), 1-20.

Martínez Valle, R. (1996). Fauna del Pleistoceno superior en el País Valenciano: aspectos económicos, huella de manipulación y valoración paleoambiental ( $\mathrm{PhD}$ Thesis). Universitat de València, València.

Martínez Valle, R. (1997). La Fauna. In J. Casabó (Ed.), Les societats depredadores del Montgó: estrategies d'aprofitament de recursos a Cova Foradada. L'excavació $i$ anàlisi preliminar de la informació arqueologica (Vol. 13-14, pp. 49-76). Denia: Aguaits.

Martínez Varea, C. M. (2019). La recolección de vegetales por los grupos humanos durante el Paleolítico superior. Frutos, semillas, tallos y hojas de la Cova de les Cendres (Teulada-Moraira, Alicante). (PhD Thesis). Universitat de València, València.

Martínez Varea, C. M., \& Badal, E. (2018). Plant use at the end of the Upper Palaeolithic: archaeobotanical remains from Cova de les Cendres (Teulada-Moraira, Alicante, Spain). Vegetation History and Archaeobotany, 27(1), 3-14. https://doi.org/10.1007/s00334-017-0616-0.

Martínez-Moreno, J., Mora, R., Benito-Calvo, A., Roy Sunyer, M., \& Sánchez-Martínez, J. (2019). A bunch of refits: 497D blade knapping assemblage of the Early Upper Paleolithic in Cova Gran (Northeast Iberia). Archaeological and Anthropological Sciences, 11(9), 4585-4600. https://doi.org/10.1007/s12520-018-0726-3.

Menargues, J. (2005). La explotación de las rocas locales en los yacimientos paleolíticos de la Ratlla del Bubo (Crevillent, Alicante) y la Cova de les Cendres (Teulada, Alicante). In M. Santonja, A. Pérez-González, \& M. J. Machado (Eds.), Geoarqueología y Patrimonio en la Península Ibérica y el entorno mediterráneo (pp. 413-424). Soria: Adema: Patrimonio Almazán.

Miralles, J. L. (1982). El Gravetiense en el País Valenciano. Saguntum-PLAV, 17, 45-63. https://doi.org/10. 7203/SAGVNTVM.0.5296.

Molina Hernández, F. J. (2015). El sílex del Prebético y cuencas neógenas en Alicante y sur de Valencia: su caracterización y estudio aplicado al Paleolítico medio ( $\mathrm{PhD}$ Thesis). Universitat d'Alacant, Alicante.

Molina Hernández, F. J., Tarriño, A., Galván, B., \& Hernández, C. (2010). Áreas de aprovisionamiento de sílex en el Paleolítico medio en torno al Abric del Pastor (Alcoi, Alicante). Recerques del Museu d'Alcoi, 19, 65-80.

Mora, R., Martínez-Moreno, J., Roy Sunyer, M., Benito Calvo, A., Polo-Díaz, A., \& Samper Carro, S. (2018). Contextual, technological and chronometric data from Cova Gran: their contribution to discussion of the Middle-to-Upper Paleolithic transition in northeastern Iberia. Quaternary International, 474, 30-43. https://doi.org/10.1016/j.quaint.2016.05.017. 
Morales, J. I., Cebrià, A., Burguet-Coca, A., Fernández-Marchena, J. L., García-Argudo, G., RodríguezHidalgo, A., et al. (2019). The Middle-to-Upper Paleolithic transition occupations from Cova Foradada (Calafell, NE Iberia). PLOS ONE, 14(5), e0215832. https://doi.org/10.1371/journal.pone.0215832.

Nicholson, R. A. (1993). A morphological investigation of burnt animal bone and an evaluation of its utility in archaeology. Journal of Archaeological Science, 20(4), 411-428. https://doi.org/10.1006/jasc.1993.1025.

Pantoja, A., Sala, M. T. N., García, N., Zapata, B. R., José, M., García, G., et al. (2011). Análisis paleontológico del yacimiento del Pleistoceno superior de Cova Foradada (Xàbia, Alicante, España). Boletín de la Real Sociedad Española de Historia Natural. Sección geológica, 105, 53-66.

Pérez Luis, L. (2019). Estrategias de subsistencia y dinámicas de asentamiento en los Valles de Alcoy durante el Paleolítico medio. Análisis zooarqueológico, tafonómico y paleoecológico de la secuencia arqueológica de El Salt. (PhD Thesis). Universitat Rovira i Virgili, Tarragona.

Pérez Luis, L., Machado, J., Hernández, C.M., Morales, J.V., Brugal, J.P., \& Galván, B. (2015). Arqueozoología y arqueoestratigrafía del yacimiento de El Salt (Alcoi, Alicante): contribución metodológica para el análisis del registro faunístico contenido en palimpsestos arqueológicos del Paleolítico medio. In A. Sanchis \& J. Ll. Pascual (Eds.), Preses petites i grups humans en el passat. II Jornades d'Arqueozoologia (pp. 223-244). València: Museu de Prehistòria de València.

Pérez Luis, L., Sanchis, A., Hernández, C. M., \& Galván, B. (2017). Paleoecología de macromamíferos aplicada a los conjuntos zooarqueológicos de El Salt y El Abric del Pastor (Alcoy, Alicante). In A. Sanchis \& J. L. L. Pascual (Eds.), Interaccions entre felins i humans. III Jornades d'Arqueozoologia (pp. 327-353). València: Museu de Prehistòria de València.

Pérez-Ripoll, M. (1992). Marcas de carnicería, fracturas intencionadas y mordeduras de carnívoros en huesos prehistóricos del mediterráneo español. Alicante: Instituto de Cultura 'Juan-Gil Albert'.

Pérez-Ripoll, M. (2004). La consommation humaine des lapins pendant le Paléolithique dans la région de Valencia (Espagne) et l'étude des niveaux gravétiens de la Cova de les Cendres (Alicante). In J. D. Brugal \& J. Desse (Eds.), Petits animaux et sociétés humaines. Du complement alimentaire aux ressources utilitaires. XXIVe Rencontres Internationales d'Archéologie et d'Histoire d'Antibes (pp. 191-206). Éditions APDCA: Antibes.

Pérez-Ripoll, M. (2005). Characterization of anthropic fractures and their typology in rabbit bones from the gravetian levels in the Cendres Cave (Alicante). Munibe, 57 Homenaje a Jesús Altuna, 239-254.

Pericot, L. (1942). La Cueva del Parpalló (Gandía). Excavaciones del Servicio de Investigación Prehistórica de la Excma. Diputación Provincial de Valencia. Madrid: CSIC Instituto Diego Velázquez.

Pettitt, P., \& Bailey, P. B. (2000). AMS radiocarbon and luminescence dating of Gorham's and Vanguard Caves, Gibraltar, and implications for the Middle to Upper Palaeolithic transition in Iberia. In C. B. Stringer, R. N. E. Barton, \& J. C. Finlayson (Eds.), Neanderthals on the edge: papers from a conference marking the 150th anniversary of the Forbes' Quarry discovery, Gibraltar (pp. 155-162). Oxford: Oxbow Books.

Poitevin, F. (1984). Biogéographie et écologie des crocidures méditerranéennes (Insectivores, Soricidés) Crocidura russula (Hermann, 1780) Crocidura suaveolens (Pallas, 1811): importance de la compétition interspécifique dans la compréhension de leurs distributions. Montpellier: École pratique des hautes études.

Potts, R., \& Shipman, P. (1981). Cutmarks made by stone tools on bones from Olduvai Gorge, Tanzania. Nature, 291(5816), 577-580. https://doi.org/10.1038/291577a0.

Rasmussen, S. O., Bigler, M., Blockley, S. P., Blunier, T., Buchardt, S. L., Clausen, H. B., et al. (2014). A stratigraphic framework for abrupt climatic changes during the Last Glacial period based on three synchronized Greenland ice-core records: refining and extending the INTIMATE event stratigraphy. Quaternary Science Reviews, 106, 14-28. https://oi.org/10.1016/j.quascirev.2014.09.007.

Real, C. (2017). Estudio arquezoológico y tafonómico del Magdaleniense de la Cova de les Cendres (Teulada-Moraira, Alicante) ( $\mathrm{PhD}$ Thesis). Universitat de València, València.

Reimer, P. J., Bard, E., Bayliss, A., Beck, J. W., Blackwell, P. G., Ramsey, C. B., et al. (2013). IntCal13 and Marine13 radiocarbon age calibration curves 0-50,000 years cal BP. Radiocarbon, 55(4), 1869-1887. https://doi.org/10.2458/azu_js_rc.55.16947.

Rey, J. M. (2007). Crocidura suaveolens (Pallas, 1811). In L. J. Palomo, J. Gisbert, \& J. C. Blanco (Eds.), Atlas y Libro Rojo de los Mamíferos Terrestres de España (pp. 125-127). Madrid: Dirección General para la Biodiversidad -SECEM-SECEMU.

Rey, J. M., \& Landin, A. (1973). Sobre la presencia de Crocidura suaveolens en el sur de Anadalucía (Mammalia, Insectivora). Boletín Real Sociedad Española Historia Natural, 71, 9-16.

Román, J. (2007). Talpa occidentalis, Cabrera 1914, 1907. In L. J. Palomo, J. Gisbert, \& J. C. Blanco (Eds.), Atlas y Libro Rojo de los Mamíferos Terrestres de España (pp. 89-91). Madrid: Dirección General para la Biodiversidad -SECEM-SECEMU.

Rots, V., \& Plisson, H. (2014). Projectiles and the abuse of the use-wear method in a search for impact. Journal of Archaeological Science, 48, 154-165. https://doi.org/10.1016/j.jas.2013.10.027. 
Saladié, P. (2009). Experimental chewing and gnawing of humans and other primates compared to canids, suids and felids (PhD Thesis). University Rovira i Virgili, Tarragona.

Sánchez Alonso, C. (2002). Chova piquigualda (Pyrrhocorax graculus). In R. Martí \& J. C. Del Moral (Eds.), Atlas de las aves reproductoras de España (pp. 544-545). Madrid: DGCN-Sociedad Española de Ornitología.

Sanchis, A., \& Villaverde, V. (In press). Restos postcraneales de Cuon en Pleistoceno superior (MIS 3) de la Cova de les Malladetes (Barx, Valencia). Saguntum-PLAV, Extra-20.

Sanchis, A., Tormo, C., Sauqué, V., Sanchis, V., Díaz, R., Ribera, A., \& Villaverde, V. (2015). Pleistocene leopards in the Iberian Peninsula: new evidence from palaeontological and archaeological contexts in the Mediterranean region. Quaternary Science Reviews, 124, 175-208. https://doi.org/10.1016/j.quascirev. 2015.07.013.

Sanchis, A., Real, C., Pérez-Ripoll, M., \& Villaverde, V. (2016). El conejo en la subsistencia humana del Paleolítico superior inicial en la zona central del Mediterráneo Ibérico. In L. Lloveras, C. Rissech, J. Nadal, \& J. M. Fullola (Eds.), What bones tell us / El que ens expliquen els ossos (pp. 145-156). Barcelona: Monografies del SERP. Universitat de Barcelona.

Savard, M. A. (2000). Etude de l'assemblage carpologique de La Baume de Fontbrégoua (Var) du paléolithique final au chasséen récent. Paris: Université de Paris I Panthéon-Sorbonne and Université de Paris X Nanterre.

Schmidt, I., \& Zimmermann, A. (2019). Population dynamics and socio-spatial organization of the Aurignacian: scalable quantitative demographic data for western and central Europe. PLOS ONE, 14(2), e0211562. https://doi.org/10.1371/journal.pone.0211562.

Seierstad, I. K., Abbott, P. M., Bigler, M., Blunier, T., Bourne, A. J., Brook, E., et al. (2014). Consistently dated records from the Greenland GRIP, GISP2 and NGRIP ice cores for the past 104 ka reveal regional millennial-scale $\delta 180$ gradients with possible Heinrich event imprint. Quaternary Science Reviews, 106, 29-46. https://doi.org/10.1016/j.quascirev.2014.10.032.

Shipman, P., \& Rose, J. (1983). Early hominid hunting, butchering, and carcass-processing behaviors: approaches to the fossil record. Journal of Anthropological Archaeology, 2(1), 57-98. https://doi.org/ $10.1016 / 0278-4165(83) 90008-9$.

Snow, D. W., \& Christopher, P. (1997). The birds of the western Paleartic. Oxford: Oxford University Press.

Stiner, M. C., Kuhn, S. L., Weiner, S., \& Bar-Yosef, O. (1995). Differential burning, recrystallization, and fragmentation of archaeological bone. Journal of Archaeological Science, 22(2), 223-237. https://doi.org/ 10.1006/jasc. 1995.0024 .

Tejero, J.-M. (2013). La explotación de las materias óseas en el Auriñaciense. Caracterización tecnoeconómica de las producciones del Paleolítico superior inicial en la Península Ibérica (BAR International Series., Vol. 2469). Oxford: British Archaeological Reports Oxford. https://doi.org/10.30861/9781407310800.

Vega, G., \& Martín, P. (2006). Análisis preliminar de las cadenas operativas en el material lítico procedente del nivel IV del Abrigo del Palomar (Yeste, Albacete). Zona arqueológica, 7(1), 396-405.

Verdún-Castelló, E., \& Casabó, J. (2020). Shellfish consumption in the Early Upper Palaeolithic on the Mediterranean coast of the Iberian Peninsula: the example of Foradada Cave. Journal of Archaeological Science: Reports, 29, 102035. https://doi.org/10.1016/j.jasrep.2019.102035.

Vidal Matutano, P. (2016). Alrededor del fuego: paisaje, clima y gestión de los recursos leñosos en grupos cazadores-recolectores durante el Paleolitico medio (Alicante, España). ( $\mathrm{PhD}$ Thesis). Universitat de València, València.

Vilette, P. (1983). Avifaunes deu Pleistocene final et de I'Holocene dans le sud de la France et en Catalogne. Carcassone: Laboratoire de Préhistoire Paléthnologique. Atacina 11.

Villa, P., \& Mahieu, E. (1991). Breakage patterns of human long bones. Journal of Human Evolution, 21(1), 27-48. https://doi.org/10.1016/0047-2484(91)90034-S.

Villaverde, V., Martínez Valle, R., Roman, D., Iborra, M. P., \& Pérez-Ripoll, M. (2007). El gravetiense de la vertiente Mediterránea Ibérica: reflexiones a partir de la secuencia de la Cova de Les Cendres (Moraira, Alicante). Veleia, 24-25(24), 445-468.

Villaverde, V., Real, C., Roman, D., Albert, R. M., Badal, E., Bel, M. Á., et al. (2019). The early Upper Palaeolithic of Cova de les Cendres (Alicante, Spain). Quaternary International, 515, 92-124. https://doi. org/10.1016/j.quaint.2017.11.051.

Walker, P. L., \& Long, J. C. (1977). An experimental study of the morphological characteristics of tool marks. American Antiquity, 42(4), 605-616. https://doi.org/10.2307/278934.

Wild, E. M., Neugebauer-Maresch, C., Einwögerer, T., Stadler, P., Steier, P., \& Brock, F. (2008). 14C dating of the Upper Paleolithic site at Krems-Hundssteig in Lower Austria. Radiocarbon, 50(1), 1-10. https:// doi.org/10.1017/S0033822200043332.

Wood, R. E., Barroso-Ruiz, C., Caparros, M., Jorda Pardo, J. F., Galvan Santos, B., \& Higham, T. F. G. (2013). Radiocarbon dating casts doubt on the late chronology of the Middle to Upper Palaeolithic 
transition in southern Iberia. Proceedings of the National Academy of Sciences, 110(8), 2781-2786. https://doi.org/10.1073/pnas.1207656110.

Wood, R. E., Arrizabalaga, A., Camps, M., Fallon, S., Iriarte-Chiapusso, M.-J., Jones, R., et al. (2014). The chronology of the earliest Upper Palaeolithic in northern Iberia: new insights from L'Arbreda, Labeko Koba and La Viña. Journal of Human Evolution, 69, 91-109. https://doi.org/10.1016/j.jhevol.2013.12. 017.

Zilhão, J. (2006). Chronostratigraphy of the Middle-to-Upper Paleolithic transition in the Iberian Peninsula. Pyrenae, 37(1), 7-84.

Zilhão, J., \& Pettitt, P. (2006). On the new dates for Gorham's Cave and the late survival of Iberian Neanderthals. Before Farming, 2006(3), 1-9. https://doi.org/10.3828/bfarm.2006.3.3.

Zilhão, J., Davis, S. J. M., Duarte, C., Soares, A. M. M., Steier, P., \& Wild, E. (2010). Pego do Diabo (Loures, Portugal): dating the emergence of anatomical modernity in westernmost Eurasia. PLOS ONE, 5(1), e8880. https://doi.org/10.1371/journal.pone.0008880.

Zilhão, J., Ajas, A., Badal, E., Burow, C., Kehl, M., López-Sáez, J. A., et al. (2016). Cueva Antón: a multiproxy MIS 3 to MIS 5a paleoenvironmental record for SE Iberia. Quaternary Science Reviews, 146, 251273. https://doi.org/10.1016/j.quascirev.2016.05.038.

Zilhão, J., Anesin, D., Aubry, T., Badal, E., Cabanes, D., Kehl, M., et al. (2017). Precise dating of the Middleto-Upper Paleolithic transition in Murcia (Spain) supports late Neandertal persistence in Iberia. Heliyon, 3(11), e00435. https://doi.org/10.1016/j.heliyon.2017.e00435.

Publisher's Note Springer Nature remains neutral with regard to jurisdictional claims in published maps and institutional affiliations.

\section{Affiliations}

\section{Valentín Villaverde ${ }^{1}$ - Alfred Sanchis ${ }^{2} \cdot$ Ernestina Badal $^{1}$. ?Miguel Ángel Bel ${ }^{1}$ - M. Mercè Bergadà ${ }^{3}$. Aleix Eixea ${ }^{1}$ • Pere M. Guillem ${ }^{4}$ • Álvaro Martínez-Alfaro $^{1} \cdot$ Rafael Martínez-Valle ${ }^{5}$ - Carmen M. Martínez-Varea ${ }^{1} \cdot$ Cristina Real $^{1} \cdot$ Peter Steier $^{6}$. Eva M. Wild ${ }^{6}$}

1 Departament de Prehistòria, Arqueologia i Història Antiga, Grupo de Investigación Prehistoria del Mediterráneo Occidental (PREMEDOC), Universitat de València, Av. Blasco Ibañez 28, 46010 Valencia, Spain

2 Servei d'Investigació Prehistòrica, Diputació de València, Museu de Prehistòria de València, C/ Corona 36, 46003 Valencia, Spain

3 SERP, Departament de Prehistòria, Història Antiga i Arqueologia, Universitat de Barcelona, C/ Montalegre 6-8, 08001 Barcelona, Spain

4 Conselleria d'Educació, Investigació, Cultura i Esport, Servei de Patrimoni cultural, Valencia, Spain

5 IVACOR, C/ Genaro Lahuerta Pintor, 25, 46010 Valencia, Spain

6 VERA (Vienna Environmental Research Accelerator) Laboratory, Faculty of Physics - Isotope Physics, University of Vienna, Währingerstraße 17, 1090 Wien, Austria 